\title{
Q6.
}

ISSN $2278-0211$ (Online)

\section{Assessing the Perception of Nigeria Undergraduates on Services Marketing Model as Tool for Prevention and Control of Crime among Undergraduates}

\author{
Dr. Jude E. Madu \\ Faculty of Business Administration, Abia State University, Uturu, Nigeria
}

\begin{abstract}
:
This study is necessitated by the increasing rate of involvement of undergraduates in crime despite measures by tertiary institutions and government to curb the menace. It is principally aimed at identifying the reasons why undergraduates get involved in crimes, and how services marketing tools can be used to curb the crime menace. Secondary and primary data were utilized, with the latter obtained by administering copies of questionnaire and interview on undergraduates, graduate students and the Chief Security Officers of the selected Universities. Data analysis was done using descriptive statistics, while all the hypotheses postulated were tested using the multiple linear regression (MLR) model. The major findings include: the main reasons why undergraduates in Nigeria commit crime are; pear influence, poverty, lack of knowledge of the consequences of crime, high cost of acquiring higher education services, lack of security within the campuses, fear of unemployment after graduation, and weak parental upbringing; quality of education services offered by the universities contributes to prevention and control of crime among undergraduates; messages posted through social media networks can be used to prevent and control crime among undergraduates; attitude of staff of the universities contributes to prevention and control of crime among undergraduates; advertising messages against crime can prevent and control crime among undergraduates if done through newspapers, magazines, and radio; public relations and publicity activities by the institutions contribute to prevention and control of crime among undergraduates. Based on these findings, the study recommends among others that for tertiary institutions to prevent and control crime among undergraduates, they should: render quality services at reduced cost; post the consequences of crime to the social media; encourage staff to act as change agent to undergraduates; promote the consequences of crime through the appropriate advertising media; and implement the recommended public relations and publicity activities. These recommendations are represented in a model as: UCB $=F(Q E S$, $A S P, S M N, A D M, P R A$, and PBA).
\end{abstract}

Keywords: Perception, undergraduates, services marketing, model, crime, change agent, deviance, target adopters

\section{Background of the Study}

Section 2 of the Criminal Code Act CAP 77 laws of the Federation of Nigeria (1990), defines a crime as "an act or omission which renders the person(s) doing the act or making the omission liable to punishment under this Code or under any Act or Law". Examples of these criminal acts are: armed robbery, rape, kidnapping, rioting, cultism or belonging to unlawful societies, grievous harm, assault, stealing, burglary, house-breaking, and many more. The same Law provides punishments for these offences which include death and long terms of imprisonment. Unfortunately, Adepegba (2011) reports that since the inception of this present democratic dispensation termed "the $4^{\text {th }}$ Republic", Nigeria has experienced an increase in the number of criminal activities. Also regrettably, a critical study of our National dailies shows an avalanche of violent criminal activities perpetrated by undergraduates in the country. Chukwu (2011) reports that in the yester years, in the University system, there was hardly anything like cultism or criminality; every student was his brother's keeper and was busy with learning and research. But today, students organize themselves into cult and terrorist groups to kill and maim fellow students, rape female students and be used as instruments of assassination, violence and electoral malpractices. These criminal activities by undergraduates are not restricted to the tertiary institution's environment. In every part of the country, incidents of undergraduate's involvements in kidnapping, assassination, cybercrimes and armed robbery with sophisticated weapons are very visible (Amuta, 2009). This situation represents grave threat to the political and economic growth and stability of Nigeria. This is because; undergraduate Youths are the future leaders of this country. Based on this; Waziri (2010) warns that if they are allowed to destroy themselves, the envisaged economic and sociopolitical growth of the country will be hampered. The situation is so bad to the extent that people are no longer free to go about their legitimate social and economic activities given the rate of criminal activities among undergraduates. All over the country, armed robbery, kidnapping, assassination, child stealing, and the likes occur almost daily. So bad is the 
kidnapped on their way to their homes, churches, work places (offices), or along the highways even in day-time with huge sums of money running in millions of naira demanded as ransom. Investors no longer feel safe running businesses in the country. Even politicians and top Government Officials no longer feel safe traveling to their home towns for fear of being kidnapped or robbed. Chukwu (2011) reports that all these events have significant undergraduate's involvement in criminal activities.

Encarta Dictionaries (2009) define undergraduates as those studying in the Universities and other Institutions of Higher learning for Bachelor's Degree or its equivalent. Bassey (2011) opines that undergraduates' involvement in criminal activities signifies serious challenges to the survival of the dreams of the founding fathers of Nigeria as majority of the so-called leaders-of-tomorrow are already heading to damnation. Based on this, it is the opinion of this study that something more significant must be done to curb this menace. Belo-Osagie and Kanebe (2012) report that some efforts aimed at curbing criminality amongst undergraduates have been made by Management of most Tertiary Institutions, Government, and even the churches, yet criminality persists amongst undergraduates. Since previous efforts to curb criminality among undergraduates have failed to yield significant results, there is need to try different measures to eradicate the menace otherwise the hope bestowed on our undergraduates as future leaders will end up being an illusion. To realize this, Aimiuwu (2009) recommends that difficult situations such as this can be remedied through the application of marketing tool and philosophies. According to Aimiuwu (2009),' Marketing provides leverage to a seemingly difficult situation especially when an exchange relationship exists. When the going gets rough, and people have to revisit first principles, go back to the basics, question their fundamental ideologies, re-examine their values, and indeed undertake strategic re-profiling, re-define their vision, and try to re-chart their journey through labyrinth of chaos and confusion, to recapture their dream, actualize their goal or realize the promised land, their marketing journey has just begun, for it is marketing, more than any other profession, that enables us: know and measure the difference between what was and what is; differentiate between what is and what can be; distinguish between what can be and what must be; define precisely the process to actualize that from the innovation chain, through the supply chain and extended supply chain, till the ultimate satisfaction of stakeholders is realized; and identify and instill discipline needed for compliance through each stage of the value chain, to ensure effective application of best principles, to achieve best practices and corporate governance standards".

The American Marketing Association (AMA) (2004) as quoted in Jobber (2004) defines marketing "as an organizational function and set of processes for creating, communicating and delivering value to customers and, for managing customer relationships in ways that benefit the organization and its stakeholders". On their part, Agbonifoh, Ogwo, Nnolim and Nkamnebe (2007), define Marketing "as consisting of individual and organizational activities designed to facilitate and expedite exchange so as to achieve the goals of the producer/seller by sensing and satisfying customer needs". Simplifying the above definitions, Ogwo (2008) as quoted in Ogwo and Nkamnebe (2009), puts it point-blank by stating that marketing aims at identifying and satisfying customer needs. The message from these definitions is that marketing aims at fostering long term relationships between the parties involved in such transactions that must play mutually-active roles in the exchange. This is because, Marketing is all about making and fulfilling promises profitably. Furthermore, there are many branches of marketing. But the branch that best suits the realization of the objectives of services rendered by tertiary institutions is services marketing (Anyanwu and Nwaokah: 2008). Lovelock and Wirtz (2011) as quoted in Financial Times Lexicon see services as economic activities offered by one party to another, most commonly employing time-based performances to bring about desired results to recipients themselves or in objects or other assets for which purchasers have responsibilities. Chand (2014) sees services as intangibles offered to capture value from customers. Based on the definitions above, services marketing can be defined as a scientific method of offering services in order to capture value from customers through the identification and satisfaction of customer needs. Services marketing focus on the distinctive characteristics of services and how they affect both customers' behavior and marketing strategy. However, Palmer (2005) notes that because of the unique features of services, the traditional 4P's of marketing (product, price, place and promotion) cannot adequately realize the objectives of services marketing. Hence, the identification and inclusion of additional 3Ps (people, process and physical evidence) to have 7Ps of services marketing (product, price, place, promotion, people, process and physical evidence). Furthermore, a Model is a representation of a true fact in a simpler form. The Encarta Dictionary (2009) defines a Model as a simplified version of something complex used in analyzing and solving problems or making predictions. Singer (2009) sees a model as a mathematical idealization in the form of a system, proposition, formula or equation of a physical, biological or social phenomenon. From the above definitions, services marketing model comprises of a blend of or the application of the services marketing tools to achieve an objective such as prevention and control of crime among undergraduates. Since previous efforts by the institutions and government aimed at curbing criminality amongst undergraduates have failed to yield the needed results as stated earlier, there is an urgent need to try other measures such as the application of services marketing model to curb the menace of criminality amongst undergraduates through the utilization undergraduates' perspectives on criminal activities among them. Perspective is how an individual understands a situation using his or her senses. For tertiary institutions to realize their objectives, they must curb criminality among undergraduates. How to realize this through the application of services marketing model is the bases for this study.

\subsection{Statement of the Problem}

In Nigeria, tertiary institutions have in the past produced great leaders that have contributed to the growth and Development of this country. Opaluwa (2000) states that criminal activities of any kind were not in Nigeria universities or tertiary institutions before 1990. But in early 1990s, what became a noticeable form of crime among undergraduates was a break-up of Protestants from the famous Pyrate confraternity (Olatunji and Abioye: 2011). Olatunyi and Abioye (2011) 
further state that the break-up was due to doctrinal differences and inability of intending members to meet required standard of the parent pyrate confraternity and that this gave way to the emergence of cult groups like the buccaneers, mafia and Vikings. The early nineties witnessed a boom of criminal activities in the Nigeria universities as every university was plagued with cult exposition such as Black Axe, Black cats, Twelve disciples, Mgba brothers, Elye, Mephitis, Temple of Eden, the Jurists, klu Klux klan, The Executioners, Black Beret, Dreaded Friends of Friends, National association of Adventures, Black scorpion, Eagle club, Termites, Read sea horses, Knight cadet, Sonmen, White angels, Amazons, Daughters of Jezebel and the Black brassieres (Obijiofor:2000). This proliferation of cult groups necessitated an increase in criminal activities perpetrated by undergraduates because of the need to fund their group, remain supreme among other cult groups and at the same time graduate from the university. To satisfy these needs, Ojedokun and Eraye (2012) state that undergraduates moved beyond cult activities to commit other crimes such as cyber related crimes (also known as yahoo-yahoo), armed robbery, kidnapping, assassination, rape, stealing and many others. To effectively perpetrate their activities, their memberships and converts increased, thus causing many undergraduates into criminality to the extent that the number of undergraduates' involvement in criminal activities recently is alarming as shown in table 1.0 below:

\begin{tabular}{|c|c|c|c|}
\hline Year & Undergraduates & Unemployed & Traders And Artisans \\
\hline 2002 & 8443 & 39045 & 31700 \\
\hline 2003 & 21,227 & 34600 & 40150 \\
\hline 2004 & 18,727 & 28705 & 19122 \\
\hline 2005 & 19,021 & 57736 & 16236 \\
\hline 2006 & 21,316 & 78049 & 25317 \\
\hline 2007 & 27,323 & 39374 & 24412 \\
\hline 2008 & 20,510 & 44560 & 25412 \\
\hline 2009 & 21,020 & 46472 & 27124 \\
\hline 2010 & 24,516 & 59520 & 32404 \\
\hline 2011 & 34,722 & 62750 & 41387 \\
\hline
\end{tabular}

Table 1: Occupational Distributions of Persons Detained in Nigeria Police Cells between 2003 to 2012 Source: Crime Statistics, Nigeria Police Force Headquarters, Abuja (2013)

From table 1.0 above, it can be deduced that a growing number of undergraduates are taking up to crime as their occupation. Again, Obijiofor (2000) opines that this trend makes mockery of universities and other higher institutions established for advancement of knowledge. Universities are not established to train students to develop expertise in crimes such armed robbery, kidnapping, fraud, cybercrimes, assassination, rape, drug related crime, and many others. Some recent nerve-gurgling cases of undergraduates involvement in criminal activities includes:

- the case of Cynthia Onukegu; a post-graduate student of Nasarawa State University who was allegedly lured to Lagos, stripped of her prized possessions, brutally tortured, raped , taunted and murdered in July, 2012 by two Accountancy students of the University of Lagos and Nnamdi Azikiwe University, Awka and their collaborators;

- the extra-judicial killing of four university of Port-Harcourt students by suspected cult group in May 2012 in a village near the university;

- In Ibadan Oyo State in May 2012, the Police paraded five students of an unnamed private university who allegedly defrauded their victims of more than $\$ 27,000.00$ (twenty seven thousand dollars;

- A report published on Tuesday 16th March, 2009 reads "A Nigeria undergraduate has been sentenced to 19 years imprisonment for obtaining $\$ 47,000$ (Forty seven thousand dollars) from an Australian woman by convincing her over the internet that he was 57 years old white, an Engineer working in Lagos who lost his wife and only child through a fatal motor accident. That he was madly in love with her. Based on the promise of marriage, the woman sent the money to him;

- in the last week of January 2007, offices of the National Drug Law Enforcement Agency (NDLEA) at Lagos International Airport arrested a 31 years old US-Based Nigeria undergraduate with 13.5 kilograms of cocaine.

- Some other body chilling reports of undergraduates' involvement in crime as quoted by Ekundayo and Osalusi (2010) are:

$>$ On June 28, 2006, a lecturer (Seyi Onyedola) was abducted and killed during a clash between cult groups at the Olabisi Onabanjo University Ago- Iwoye Ogun State.

$>$ In October 2003, three students of Kwara State polytechnics were killed by cult rivals inside the school compound.

> Mr. Yomi Adeki, a staff of University of Benin was killed on February $4^{\text {th }} 2011$ by cultist.

Also recently, Wikipedia reports through the internet download reveals that:

- On September $4^{\text {th }} 2015$, the Student's Affairs division of Akwa-Ibom State University released a notice indicating the expulsion of six (6) students for various offences. Their photographs were equally pasted on the walls inside the campus for public view. Their names and respective offences as published are as shown in table 2 below. 


\begin{tabular}{|c|c|c|c|}
\hline S/N & Name & Department & Offense \\
\hline a. & Okokon Eno-obong & 300 level English \& Literary Studies & Stealing/theft \\
\hline b. & David Mbotobong Sunday & 300 level political science & Stealing \\
\hline c. & Ernest Michael Ufia & 100 level Electrical Engineering & Cultism \\
\hline d. & Leonard Christopher Inyang & 200 level civil Engineering & cultism \\
\hline e. & Murine Akpe Ndunofit & 300 level Agric Engineering & Cultism \\
\hline f. & Joseph Jackson Nse & 400 level Geo-Science & Cultism \\
\hline
\end{tabular}

Table 2: Data of Expelled Students of Akwa-Ibom State University for Criminal Offences

Source: www.nairaland.Com (2015)

- $\quad$ On Saturday $10^{\text {th }}$ July 1999, five (5) students of Obafomi Awolowo University were killed while eleven (11) were seriously wounded by an organized death squad of 40 members of Black Axe confraternity branch of the university.

- The list is unexhaustive, but most worrisome is the punishments such as death, imprisonment and rustication from the universities melted on these undergraduates. Therefore, if the supposed future leaders of tomorrow' are destroyed before the tomorrow as a result of their involvement in criminal activities, then the dream of attaining socio-economic growth is illusive in the country. Also, the involvement of undergraduates in criminal activities makes it difficult for the universities or tertiary institutions to realize their objectives because learning cannot be achieved in an unsecure environment. Therefore, stringent efforts need to be made urgently to stem the tide of menace of criminality, among undergraduates.

Oyetunde (2000) confirms that efforts have been made in the past by the University management, the government and even the churches to curb criminality among undergraduates yet the menace persists. Some of these efforts as reported by Belo- Osagie and Kanebe (2012) are: (a) Arrest, detention and prosecution of students involved in crimes by the police; (b) rustication of students involved in any form of crimes; (c) Organizing religious activities periodically for students in the form of crusades and preaching by clergies; (d) mounting of sign posts in several locations within the institutions with massages showing the consequences of criminality (e) ban on students union activities; (f) publication of school magazines and leaflets with massages aimed at discouraging students' involvement in cultism and other criminal activities. Unfortunately, these efforts seem not to have yielded reasonable results. This assertion is supported by the reports of Amuta (2009) and Anya (2009) that there is hardly any week that a student in a Nigeria tertiary institution is not reported or arrested for criminal offences that attract punishments of imprisonment or death sentence. These reports were further re-enforced by Egbule (2006) and Ori (2012) who noted that the involvement of undergraduates in criminal activities is worrisome given the consequences. These consequences include: (a) some of the undergraduates are killed while many are injured or disabled permanently; (b) some are sent to prisons for many years; (c) most of the undergraduates live in perpetual fear as a result they abandon their educational pursuit; (d) there is general insecurity in the tertiary institutions; (e) there is an increase in the cost of managing tertiary institutions because of increase spending on security; (f) parents withdraw their wards from such institutions for fear of insecurity and send them to universities in foreign countries, thus creating an unfavorable balance of payment arising from huge expenditure on importation of knowledge and weak per capital income as a result of loss of employment in the education sector; and (g) investors are unwilling to invest in the tertiary institution industry for fear of low return on investment thus, weakening the Nigeria economy. Since all efforts made to curb criminality among undergraduates in Nigeria have failed to yield the needed result, there is need to try some other measures such as the application of service marketing model. A critical study of the efforts made by the institutions or university management proved that their main focus was on cultism, thus disregarding other forms of criminality perpetrated by undergraduates which are evidenced in tables 3 below.

\begin{tabular}{|l|c|c|}
\hline S/N & Offences Against Persons & Offences Against Properties \\
\hline 1. & Murder/Assassination & Armed robbery \\
\hline 2. & Manslaughter & Demanding with menace \\
\hline 3. & Attempted murder & Theft and stealing \\
\hline 4. & Suicide related & Obtaining by false pretenses and cheating \\
\hline 5. & Grievous harm/wounding & Foregoing and impersonation \\
\hline 6. & Assault & Receiving stolen property \\
\hline 7. & Child stealing/human trafficking & Rioting and arson \\
\hline 8. & Rape and indecent assault & Malicious damages and vandalization \\
\hline 9. & Unnatural offences/prostitution & Election related offences \\
\hline 10. & Belonging to unlawful & Examination malpractice \\
\hline 11. & Threatening violence & Suicide related \\
\hline \multicolumn{2}{|c|}{ Table 3: Reported Offences/Crimes Allegedly Committed by Nigeria Undergraduates (2003-2012) } \\
\hline \multicolumn{2}{|c|}{ Source: Crime Records Obtained from the Nigeria Police Headquarters, Abuja (2013) }
\end{tabular}

Furthermore, these previous efforts to prevent and control criminality among undergraduates by the institutions, government and even the churches have not been able to realize the expected results because they have minimal 
marketing orientation. None of these measures initially identified the reasons for undergraduates' involvement in crime (need identification), developed programs for curbing criminality among the undergraduates based on these identified reasons for criminality (development of products and programs to satisfy identified needs), and executing these programs in a manner that could curb all forms of criminality among undergraduates (executing the programs and strategies in such manner that would satisfy the target market and yield profit to the marketer). These steps correspond with the marketing steps and processes (Kotler and Keller:2006, Kotler and Armstrong :2005, and Kotler and Roberto: 1989). Hence, the need to consider the application of marketing philosophies or tools to prevent and control crime among undergraduates. Tertiary institutions render education services through the provision of knowledge. The branch of marketing that suits the realization of the objectives of tertiary institutions (or universities) is services marketing (Anyanwu and Nwaokeh: 2008). As stated earlier, services marketing is an organized method of offering services in order to capture value from customers through the identification and satisfaction of the customer's needs. Lovelock, and Wirtz (2011) see services as an economic activity offered by one party to another, most commonly employing time-based performances to bring about desired results in recipients themselves or in objects or other assets for which purchasers have responsibility. They moved further to define services marketing as to include building loyalty, managing relationships, complaint handling, improving service quality and productivity of service operations, and how to become a service leader in your industry. From these definitions, what is special about services marketing is that it focuses on the distinctive characteristics of services and how they affect both customers' behavior and marketing strategy. These distinctive characteristics of services include: intangibility, heterogeneity/variability, perishability and inseparability. However, given the unique feature of services, services marketing is executed through the service marketing variables (7Ps); these are: products, price, promotion, place, people, process and physical evidence. The application of the first four variables is the same as in goods marketing except for product which is slightly different. In service, the product is intangible, heterogeneous, and perishable and consumed at the point of production (inseparable). Just as in goods marketing, product is the major determinant of the service quality. Berry and Parasuraman (1991) state that the essence of services marketing is services. And that services quality is the foundation of services marketing. Since other marketing variables compliment the product to determine the expected quality in goods marketing, the same thing is applicable to services quality in services marketing. No wonder that in services marketing, products are referred to as services offer.

It is worthy to also note that universities and other tertiary institutions (especially those owned by the Government are not principally established for business purposes (that is profit maximization). They are mainly established to offer education services which are essential to the citizens. Therefore, all the services marketing variables (especially those with more business orientation like warrantees, packaging, Price level, Channel type and storage) may not be applied in forming the descriptors of this study (Baridam:1995). Based on this, there is need to identify and select the appropriate services marketing tools that could best prevent and control crime among undergraduates. Chapman and Cowdell (1998) recommends that the most suitable services marketing variables for prevention and control of crime among undergraduates in public institutions are: quality of education services offered by the institutions (product), attitude of staff (personnel) of the institution (people), social media network (promotion), selected advertising media (promotion), public relations (promotions) and publicity activities (promotion). Please note that some of the measures earlier taken by the universities management such as mounting of sign posts in several locations within the institutions with massages showing the consequences of criminality and publication of school magazines and leaflets with massages aimed at discouraging students' involvement in cultism and other criminal activities may be similar to these selected services marketing tools. But they could not yield the needed result because their usage did not conform to the marketing process as identified earlier. Another unique feature of this study is that undergraduates' perspective over criminality among undergraduates is utilized as the source of primary data for the study. The Webster Dictionary as quoted by Lovelock and Wirtz (2011) defined perspective as the ability to understand or become aware of a phenomenon through the use of the senses. Furthermore, to verify the nature of the effect of these selected variables on prevention and control of crime among undergraduates, a pilot study was conducted by the researcher. By so doing, twenty-five copies of the Questionnaire used for this study were distributed to the final year students of Law departments in the five Universities chosen (that is five students in each University). Though other services marketing tools not directly mentioned are used as part of the determinants of service quality, these services marketing variables selected, form the basis of further discussions in this study. Also note that a blend of these services marketing variables shall be used to form the bases for developing services marketing model for prevention and control of crime among undergraduates.

\subsection{Objectives of the Study}

The major objective of this study is to identify the reasons for criminalities among undergraduates in Nigeria tertiary institutions, as well as to determine how services marketing tools can be applied to prevent and control criminalities among undergraduates in Nigeria tertiary institutions. But specifically and based on the services marketing variables stated in the problems identified earlier, the following objectives shall be realized through this study.

- To assess the impact of the quality of educational services offered by the universities on crime prevention and control amongst undergraduates.

- To assess the impact of attitude of staff/personnel of universities on crime prevention and control amongst undergraduates.

- To assess the impact of messages through the social media by the universities on the prevention and control of crimes among undergraduates.

- To determine the extent to which the use of adverting messages against crimes on selected advertising media by universities can realize the objective of prevention and control of crimes among undergraduates. 
- To determine the extent to which the use of appropriate public relations activities by universities can realize the objective of prevention and control of crimes among undergraduates.

- To determine the extent to which the use of appropriate publicity activities by universities can realize the objective of prevention and control of crimes among undergraduates.

\subsection{Research Questions}

To realize the objectives of this study, answers shall be provided for the following research questions.

- To what extent does the quality of education services offered by the universities contribute to crime prevention and control amongst undergraduates?

- To what extent does attitude of staff (personnel) of universities contribute to prevention and control of crime amongst undergraduates?

- To what extent can the use of social media network by universities contribute to crime prevention and control among undergraduate?

- To what extent can the use of adverting messages on the consequences of crime by universities through selected media achieve crime prevention and control among undergraduates?

- To what extent can the use of public relations activities by universities achieve the objective of crime prevention and control among undergraduates?

- To what extent can the use of publicity activities by universities achieve the objective of crime prevention and control among undergraduates?

\subsection{Research Hypotheses}

To realize the objectives of this study and to further provide answers to the questions stated above, the following hypotheses have been postulated.

- $\mathrm{H}_{1}$ : There is no significant relationship between the quality of education services offered by universities and prevention and control of crime among undergraduates.

- $\mathrm{HO}_{2}$ : There is no significant relationship between attitude of staff (personnel) in universities and prevention and control of crime among undergraduates.

- $\mathrm{H}_{3}$ : There is no significant relationship between activities on social media networks by universities and Prevention and control of crime among undergraduates.

- $\mathrm{HO}_{4}$ : The use of selected advertising media by universities in the fight against crimes has no significant effect on prevention and control of crime among undergraduates.

- $\mathrm{H}_{5}$ : The use of selected public relations activities by universities has nosignificant effect on prevention and control of crimes among undergraduates.

- $\mathrm{H}_{6}$ : The use of selected publicity activities by universities has nosignificant effect on prevention and control of crimes among undergraduates.

\subsection{Significance of the Study}

Recall that the major objective of this study is to identify the reasons for criminalities among undergraduates in Nigeria tertiary institutions, as well as to determine how services marketing tools can be applied to curb the menace through the development of a services marketing model. Therefore, the result of this study shall be of immense relevance to the Government, management of tertiary institutions, undergraduates, parents, investors and marketing scholars. This relevance shall be in the following forms:

For the Government, the findings of this study if utilized will reduce the cost associated with the provision of security in the Institutions and country. This cost can be utilized in other vital sectors. This is in line with the contribution by Nwaezeh (2006) who advises that the earlier Nigeria Government and its Security Agencies stop criminality among Students, the better for the country.

For the University Management, the study shall enable universities or tertiary institutions management realize its objectives which can only be possible when the University environment is devoid of criminality. According to Redmond (2008), a University is expected to execute three basic functions, namely:

- To impart manpower skills;

- To contribute to national and international dialogue and criticism; and

- To act as center of research.

Unfortunately, the involvement of students in criminal and anti-social activities is making it difficult for University Management in Nigeria to realize their objectives. This difficulty shall be minimized through the application of the recommendations of this study.

For the undergraduate youths, the study will make them avoid criminality, and then focus their attention on realizing their main objective which is learning. Brickman (2009) notes that a University is expected to organize the communication of knowledge which is developed through learning. This said knowledge will qualify one for professional activities or for employment.

For Parents, this study will save them the cost of sending their children overseas (including neighboring African Countries) for University education because of the increase in criminal activities in Nigerian Universities. Adebayo (2000) notes that the situation is unbearable as many students and staff of the Universities lose their lives to these unprecedented criminal activities in Nigerian Universities. As a result, parents send their children oversee for University Education for 
fear of insecurity in Nigerian Universities. This problem shall also be controlled with the findings and recommendations of this study.

For intending Investors in the tertiary institutions in Nigeria, this study shall enkindle their expectation for possible recovery of their investment which they thought will be difficult to achieve because of exodus of Nigerian students to foreign Universities mostly for fear of insecurity. Okoye (2009) states that this fear is because Nigerian Universities are now known for the proliferation of different acts of violence, bloodletting and devilish use of ammunition, charms, acid and other dangerous weapons by cult groups who fight one another for trivial matters.

For Marketing Scholars, this study shall be of immense importance to them in developing theories and making postulations for understanding, predicting and influencing behavior of undergraduates for the purpose of crime prevention and control among the undergraduates which is inimical to marketing education services by tertiary institutions.

\subsection{Scope of the Study}

The scope for this study shall take two forms, namely: Geographic scope and Subject scope.The Geographic scope will include Universities in the South-Eastern states in Nigeria. The states are; Imo, Abia, Anambra, Enugu and Ebonyi States. Furthermore, information obtained from Force crime statistics, 'F' Department, Nigeria Police Force Headquarters Abuja (2012), proves that until (2012) when the upsurge of "Boko Haram" Terrorist attacks in some parts of Northern states became notorious, criminal activities such as kidnapping, armed robbery, ritual killing, cultism, Burglary and stealing are more prevalent in the South-Eastern States. These reasons therefore give the impetus to believe that the study of Universities in the South-Eastern states will provide reliable and valid data that can be easily generalized. Supporting this view, Baridam (1995) notes that reliability and validity are two important constructs in the measurement of research variables. Therefore, the geographical scope of this study is reasonable.The Subject scope of this study focuses on Services Marketing tools and their application on prevention and control of crime among undergraduates. Based on this, the major topics to be covered shall include: The nature of University education, the meaning of crime, Causes of students' involvement in criminal activities in Nigeria, concept of Services Marketing and its strategies, factors that affect undergraduates change in behavior, and models of social changes.

\subsection{Definition of Terms}

Some of the terms that will be used in this study and that may require further explanation are:

- Change Agents: These include academic staff of tertiary institutions whose activities are aimed at changing the criminal behavior of undergraduates.

- Crime: Acts of undergraduates that are against the provisions in Nigeria criminal laws.

- Deviance: The involvement of undergraduates in criminal activities.

- Market: These are undergraduates whose needs for learning and Degrees are to be satisfied by the university management.

- Model: How to use services marketing tools to prevent and control crime among undergraduates.

- People: These are the staff that renders university services to students.

- Perspective: Perspective is how an undergraduates understand criminality among undergraduates using his or her senses

- $\quad$ Process: These are the steps taken by the tertiary institutions to execute crime prevention and control among undergraduates.

- Promotion: This is the process of communicating the value of crime prevention and control and the consequences of crime among undergraduates in tertiary institutions.

- $\quad$ Price: These comprise of regular payment of tuition and avoidance of criminality by undergraduates in return for the services rendered by the university management.

- Product: Prevention and control of criminality among undergraduates in Nigeria tertiary institutions.

- Services: Intangible offers by tertiary institutions to prevent and control crime among undergraduates.

- South-Eastern States: These are states located in the south-east zeo-political Zone in Nigeria.

- Target Adopters: These are undergraduates whose criminal behaviors are to be changed by the change agents

- Undergraduates: These are students studying for first degrees and diplomas in tertiary institutions.

- Youths: Persons aged between 17-45 years.

\subsection{Organization of the Study}

The main work is organized in five chapters:

- Chapter one tagged "Introduction", is made up of subsections such as Background of the Study, Statement of the problems, Research objectives, Research questions, Research hypotheses, Significance of the study, Definition of terms and Organization of the study.

- Chapter Two captioned "Review of related literature", is devoted to in-depth review of topics relevant to the study as contained in Text Books, Journals, Newspaper, Magazines, and dissertations of some PhD holders in Marketing. The chapter sub-divided into empirical framework, theoretical framework and conceptual framework.

- Chapter Three termed "Research Methodology" concentrates on the explanations of the ways, means and rationale of the study. It houses topics, such as, Research Design, Selection of Data, Method of Data Collection, Design and 
Administration of Data, Populations of Study, Sample Size Determination, Reliability and Validity of Research Instrument, Data Analysis, Technique and Tools for Testing Hypotheses.

- Chapter four tagged "Data Analysis and Interpretation" contains the analysis and interpretation of Data. It also contains Test of Hypotheses using relevant statistical tools and discussion of findings.

- Finally, chapter five captioned, "summary of findings, conclusion and recommendations", contains research findings, conclusions and recommendations. The recommendations were used to develop a model for preventing and controlling criminality among undergraduates through the use services marketing model. It also contains suggested areas for further research.

\section{Review of Related Literature}

\subsection{Preamble}

The purpose of this chapter is to review the opinions of others on issues that are relevant to this study and situate them within the context of our framework. Basically, the topics in this chapter shall be discussed under empirical framework, theoretical framework, and conceptual framework.

\subsection{Empirical Framework}

This section contains reviewed literature developed through experiments and personal experience of scholars. They are published in journals, newspapers, magazines and the internet. For this study, the major topics under this section are: reports of criminal activities by students in tertiary institutions; types of criminal offences committed by undergraduates; effects of criminality among undergraduates; reasons for criminal activities by undergraduates; efforts aimed at eradicating crime among undergraduates; suggested solutions to the menace of crime among undergraduates in Nigeria.

\subsubsection{Reports of Criminality amongst Undergraduates in Nigeria}

Some of the reports of criminality amongst students in Tertiary Institutions in Nigeria are evidenced as follows: Adebayo (2000) reports that in 1997, the Secretary General of Students Union Government (SUG) at University of Benin was killed by cult members for honoring invitation by the school authority. In the same year, the principal Assistant Registrar of Delta State University Mr. Peter Otoso was murdered in cold blood by students-cultist over issues boarding on school administration. Mr. Ilege G., a Head of Department of Business Administration in IMT Enugu was shot inside his office by a female cultist. And also, a final year Banking and Finance Student of Ondo State University Ado Ekiti was killed for deflecting to a rival cult group. This is as reported in The News Magazine of $21^{\text {st }}$ August, 2000.

This day Newspaper of September 2006 reports that In July 1999, seven (7) undergraduates of Obafemi Awolowo University (OAU) Ife were murdered in cold blood while sleeping in their Hostels. The Chief Security Officer (CSO) of University of Ibadan was brutally killed by cult members in the presence of his wife and children. And 24 students arrested over killing of DPO and others during youths restiveness in Ughelli North Delta Sate.

Other Newspaper Headlines that are of relevance to this study are:

- Sexual harassment in Nigeria Tertiary Institutions gets messier. -- This day Newspaper, August 25, 2010.

- Why we killed our 70-year-old step-mother, burnt her handset and stole her N35,000.00: Re: Obinna Ndubuisi (26 years) Ebuka Ndubuisi (25 years), both of Oko Polytechnic. -- The Nation August, $6^{\text {th }} 2011$.

- Six students arrested over murder of Assembly Aspirant in Akwa Ibom State. --This day Newspapers, January 24th 2011.

- British-born Nigerian undergraduate in London involved in Terrorist Activity -- This day December $31^{\text {st }} 2009$.

- Troubled varsity: Cultist again rear their ugly head at Obafemi Awolowo University Ile-Ife, five students lost their lives, many kidnapped victims thrown into the River. -- The News 21 $1^{\text {st }}$ August, 2000

- Scuttled Missions: About 6000 students of Nnamdi Azikiwe University barricaded the Enugu-Onitsha Express Road in protest of deplorable condition of the University and prevented President Olusegun Obasanjo and his entourage from passing through the Express Road. The students' brandished dangerous weapons and burnt tyers. -- The News, 21 st August, 2000.

- IMT Student and Five others arrested in assassination attempt on Hon. Christopher Ani at Enugu Ngwo on 24/10/2010. --The Dawn Newspaper, January 25th 2011.

- Insecurity in the land: Varsity Students join cult groups to coerce incorruptible lecturers into awarding them good grades in courses. Rascal members of cult groups arm themselves with violent implements and fight one another over ownership of girlfriend and other trivial matters. This day August 29, 2009.

- Gang Rape in Abia State University: Attorney General of the Federation demands Police Report. -- This day $21^{\text {st }}$ January, 2012.

- Cult war continues in Bayelsa: Two more students killed. --This day November 12, 2010

- Why Nigeria Varsities fail world ranking: Insecurity in the campuses, inclement environment, poor funding. Lack of basic technology and erratic power are some of the factors that make varsities in the country to rank poorest globally. --The Nation, February 23, 2012.

- Student's Union government banned in University of Calabar because of crises amongst students agitating for political positions. --The Nation Magazine, February 23, 2012. 
- $\quad$ Pain in the Dress: Many Tertiary Institutions in Nigeria have come up with measures to curb indecent dressing all to no avail. -- The Nation, February 23, 2012.

- World cyber Crime: Nigeria Ranks $65^{\text {th }}$ out of 233 countries in the world for malicious activities on the internet. -The Nation October 28, 2011.

- Police arrest seven undergraduates at Yaro Ogun State and recovered three (3) locally made pistols, several cartridges, handsets and hand gloves. --The Nation October 28, 2011.

- $\quad$ Face book murder: why we killed Cynthia. A 24 -years old Cynthia Onukogu was allegedly murdered on July 22, 2012 in a Hotel in Lagos State by an undergraduate and one other. --The Sun Newspaper, Thursday August 13, 2013.

- On August 15 2012, the vice Chancellor of ESUT Prof. Cyprian Onyeji was kidnapped at the University gate by gunmen. --The Sun Newspaper, Thursday August 13, 2012.

- 2 graduates, technician arrested for kidnapping in Lagos. -The Sun Newspapers, Thursday October 18, 2012.

- Poly Student leads deadly robbery gang: Specializes in Stealing Tricycles. --The Sun Newspapers, Thursday, June 13, 2013.

- Two UNIUYO Students killed, as students protest fees increase. -The Sun Newspapers, Thursday, , June 13, 2013

- Police parade12 students, trader for cultism. --The Nation, Thursday, July 4, 2013.

Another stunning revelation is a report by The Sun Newspapers of $4^{\text {th }}$ September (2012) captioned 'the way Nigeria students in Tertiary Institutions take their own lives: Rampant cases of undergraduates taking own lives rock Nigeria Tertiary Institution'. In the report, the Reporter; Ori (2012) states that the main cases identified are:

- Onyebuchi Okonkwo; a 300 level Physics/Astronomy Student of UNN on Shell Scholarship whose body was found hanging in an uncompleted building behind the hockey ground.

- Kehinder Akintola; a 23 years- old Civil Engineering Student of Federal University of Technology Akure, whose lifeless body was found in a Hotel at Ibadan Oyo State

- Maliu Awolumate: A 27 years old ND graduate of Business Administration of Ogun State Polytechnic committed suicide. His body was found hanging on a rope from tree at Ifon Area of Ogun State.

- Towobola Adeniran; 24 -years old 100 level marketing student of College of Education Oro, He committed suicide because his only source of livelihood (Okada Motorcycle) was stolen.

Akor (1994) and Adewale (2005) as quoted by Ajayi, Ekundayop and Osalusi (2010) state that one of the earliest report of secret cult violence occurred at the University of Nigeria Nsukka in 1985 when a non-cult student was killed for snatching a cult leader's girlfriend. They also reported the following:

(a)In 1991, a student of University of Port-Harcourt was beheaded during a feud between cult members.

- At Delta State University, Abraka, the activities of cult groups resulted in the death of a principal Assistant Registrar and his wife.

- $\quad$ On $5^{\text {th }}$ August 2002, a 300 level Economics student was shot dead and slaughtered at Dallimore area of AdoEkiti. Ekiti State. In the same University but on $8^{\text {th }}$ June 2006, Cult students killed three students, wounded many other students and a staff of the University.

The Authors also quoted Omoegun and Akanle (2007), Jamiu (2008) and Ogidefa (2008) who report as follows:

- $\quad$ On June 28, 2006 a lecturer (Seun Oyedola) was abducted and killed during a clash between cults at the Olabisi Onabanjo University Ago-Iwoye Ogun State;

- In October 2003, three students of Kwara State Polytechnic were killed by cult rivals.

- $\quad$ Yomi Adeki, a staff of University of Benin was killed on February $4^{\text {th }}, 2011$ by cultist.

- $\quad$ Tuesday March 9, 2004. Vincent Uloho of University of Benin, was murdered by persons believed to be cult groups.

- July 2004, Wale Adeyori and Banji of the Federal Polytechnic Illaro, were also killed inside the school compound.

- $\quad$ Ashifat Olatunji Saheed, a student of the Polytechnic Ibadan was slaughtered in March, 2005.

- Gbenga Joseph, a policeman attached to anti-cult squad of Kwara State Police Command was killed by suspected cultist in June 2005.

\subsubsection{Types of Criminal Offences Committed by Undergraduates in Nigeria}

From the afore-reports on the prevalence of criminality amongst undergraduates in Nigeria tertiary institutions, it could be deduced that students are mostly involved in the following criminal activities:

- Cultism

- Armed Robbery

- Suicide related offences

- $\quad$ Rioting

- Kidnapping

- Cyber Crime

- Assassination/Murder

- Prostitution

These reports are supported by crime statistics presented on Tables 4. and 5 


\begin{tabular}{|c|c|}
\hline Offences & Rate \\
\hline Murder & 2000 \\
\hline Manslaughter & 2 \\
\hline Attempted Murder & 389 \\
\hline Suicide & 199 \\
\hline Grievous harm and wounding & 26,434 \\
\hline Assault & 32,838 \\
\hline Child Stealing & 59 \\
\hline Rape \& Indecent Assault & 1,718 \\
\hline Kidnapping & 372 \\
\hline Slave Dealing & 11 \\
\hline Unnatural Offences & 361 \\
\hline Belonging to unlawful societies (cultism) & 10,151 \\
\hline Total & 74,585 \\
\hline
\end{tabular}

Table 4: Offences against Persons Commited by Nigeria Undergraduates (2003 - 2012)

Source: Crime Statistics Obtained from Nigeria Police Force Headquarters Abuja, 2013

\begin{tabular}{|c|c|}
\hline Offences & Rate \\
\hline Armed Robbery & 2863 \\
\hline Demanding with menace & 63 \\
\hline Theft \& Stealing & 41901 \\
\hline Burglary & 3501 \\
\hline House Breaking & 4974 \\
\hline Store Breaking & 3510 \\
\hline Obtaining by False Pretenses \& Cheating & 6395 \\
\hline Forgery & 519 \\
\hline Receiving Stolen Property & 7308 \\
\hline Unlawful Possession & 8666 \\
\hline Arson and malicious damage & 1010 \\
\hline Cyber/Bank related crimes & 6744 \\
\hline Total & 87.454 \\
\hline
\end{tabular}

Table 5: Offences against Property Commited by Nigerian Undergraduate (2003-2012)

Source: Crime Statistics Obtained From Nigeria Police Force Headquarters Abuja, 2013

\subsubsection{Effects and Reasons of Criminality among Undergraduates in Nigeria}

From the crime statistics in Tables 4 and 5 above, Tertiary Institutions in Nigeria which ought to be ideal places for the training of minds have become war zones were terror is unleashed; students are now fully involved in destruction of life and properties including theirs. The resultant effects of these as indicated by Opaluwah (2009), Jamiu (2008) and Egbule (2006), are as follows:

- Colossal loss of life and infrastructure whose funds equivalent would have been used for other developmental projects.

- The quality and quantity of education is weakened.

- Destroys the image of the institution and the country.

- There is promotion of health-related problems such as HIV through prostitution and rape

- Leads to incarceration, rustication or expulsion of both innocent and criminal-minded students from the tertiary institutions.

- There is constant fear of insecurity in the campuses

- There is the proliferation of all forms of illegal weapons at all nocks and crannies of the tertiary institutions, cities, towns and villages.

\subsubsection{Reasons for Criminality amongst Undergraduates in Nigeria}

From the foregoing, the rate of student's involvement in criminality is very worrisome. None of these criminal offences stated in Tables 4 and 5 above carry punishments of imprisonment for less than three years, some attract death penalties, while some attract life imprisonment. Regrettably, Ori (2012) laments that criminality amongst undergraduates runs counter to the ideas and aspirations of Tertiary Institutions. Complimenting this outcry, Ogbu (2001) states that a Higher Institution is a hallowed centre for perfection, and an arena for the promotion of good ethical behavior, and not a place where criminality should be conceived. Based on these, one begins to wonder why those believed to be leaders of tomorrow subscribe to criminality. Some of the reasons adduced for students' involvement in criminality are as follows:

- Orii (2012) reports that some of the identified causes of criminality are: depression, frustration, exam failure, unsuccessful academic ventures, betrayals or death of loved ones and sponsors, poor family surveillance, and spiritual or psychiatric problems. 
- Egbule (2006) gave reasons for criminality amongst Nigeria undergraduates as general insecurity in the country, need for recognition by other students, student's politics, economic handicap of students, unfettered heartlessness and group protection. This revelation is complimented by the following reports:

- Peer group influence: Peer group means persons within very close age range or social status. It includes close friends and associates that an individual identifies with and can always be found with. Bisong (2010) opines that peer group influences one another because they do almost everything in common. Therefore, if one's friend is a criminal and probably exhibits affluence as a result of his involvement in criminality, it is very easy for one to join him and commit crime.

- Poverty or hardship: This is a state of financial helplessness. Momodu (2010) states that many parents find it difficult to fund their wards in Tertiary Institutions. Therefore, to survive and fund their education, students (especially the desperate ones) resort to criminality. Awake (2005) reports that some undergraduates come from very poor background; they have experienced varying degrees of failure in life and at the same time have unresolved personal conflict. The only way to get out of this ugly situation for them is to commit crime.

- Lack of knowledge of the consequences and constituents of criminality: Most times, undergraduates involvement in criminality is their inability to know that some of the actions they take constitute crime, and that these criminal actions attract serious punishment. Nwaezeh (2006) suggests that consistent promotional activities should be executed by both government and the school management to discourage undergraduates from criminality and also insulate them against what constitutes crime. This reason according to Nwaezeh (2006) is because some Undergraduates get involved in crime while helping their friends or because they see others doing the act. A good example is in Rape, Rioting and destroying or vandalizing government (University) properties.

- High cost of acquiring education and lack of security on the campuses: Mafuyai (2012) reports that inclement environment; poor funding and lack of basic amenities in the campuses have increased the cost of acquiring higher education in this country. And that sometimes to protest against these, students get involved in criminality. Also, Ehiede (2007) states that undergraduates cash-in on weak security network in the campuses to commit crime.

- Fear of unemployment after graduation: Abubarkar (2010) asserts that the level of unemployment in the country is becoming unbearable and that only a focused and sincere leader can save Nigeria from this ugly situation. Based on this assertion, Okoye (2009) and Dimeji (2010) in their separate contributions states that youths resort to crime because they see it as the only way to survive in the country since they are not sure of employment after graduation.

- Greed and Quest to maintain social class by undergraduates: Aliu (2010) reports that youth's desperation for money has led them to commit crimes, and that the greedy mindset of highly placed Nigerians has influenced majority of the undergraduates who see these leaders as their reference group. Furthermore, Krasner and Ullman (1973) state that children of the affluence who are suffering from identity confusion would want to be identified by a known group. To achieve this, they join a cult group who will provide a social protection for them.

- Weak parental upbringing: Parents membership of cult group is an encouragement for undergraduates' involvement in cultism and other forms of criminality. Again, Okoye (2009) reports that these parents not only encourage their children to join the cult group, but also canvass for executive position and supremacy for them. To maintain these positions and supremacy, undergraduates commit crime. Furthermore, Awake (2005) asserts that some undergraduates come from single- parents homes, and having communication problems with their parents traumatizes them. To over-come the trauma, the undergraduates join cult groups where they think they can have solace.

- Societal decadence: Crime is beginning to be seen as a normal business in Nigeria. Ogunbameru (1997) laments that since Nigerians honor criminals especially at top Government levels, the undergraduates see crime as a way of life.

- Erosion of educational standard: Educational standard have fallen in Nigeria. Ajayi, Ekundayo \& Osalusi (2010) note that less emphasis on competence has provided enabling environment for criminality amongst students.

- Militarization of the Nigeria polity: Adewale (2005) reports that the culture of violence which has become part of the Nigeria polity has given rise to political violence and assassination, activities of ethnic militia and communal clashes.

Though some of the reasons above sound pathetic, the point remains that criminality is inimical to the realization of the objectives of Tertiary Institutions. Therefore, criminality amongst undergraduates must be eradicated.

\subsubsection{Efforts Aimed at Eradicating Crime among Undergraduates in Nigeria}

Though the situation is a turbulent type, yet some identified efforts have been made by relevant bodies to prevent and control criminality among undergraduates in tertiary institutions in Nigeria. These include the efforts by the management of tertiary institutions, the Government, and the Church. These efforts are x-rayed below.

\subsubsection{Crime Prevention and Control Measures by Institution's Management}

According Makanjuola (2000), the major efforts made by management of Tertiary Institutions in Nigeria to curb the menace of criminality amongst undergraduates are:

- Setting up of internal school security men to identify criminals amongst undergraduates. This team also helps government Security Agents in arresting criminals in the campuses. 
- Rustication or suspension of undergraduates involved in criminality.

- Organizing religious activities for students to draw them closer to God and avoid criminality.

- Mounting of billboards in several locations within the school compound with messages showing the consequences of criminality.

- Publication of internal magazines and leaflets with messages aimed at discouraging student's involvement in criminality.

- Organizing public lectures and seminars where the consequences of criminality (especially cultism) are stressed using very important personalities. Most of these personalities are old students of the Institutions.

- Offering of incentives to undergraduates who publicly denounce criminality. Some of these incentives according to Adebayo (2000) include:

- offer of scholarship for post graduate studies;

- offer of automatic employment after graduation;

- exemption from certain fees or allowed to pay less fees than other students;

- they are given administrative positions in student's Union Government; and

- They are given free accommodation within the school compound and personal security attached to them until they $g$

2.2.5.2. Efforts by the Nigeria Government to Eradicate Criminality amongst Undergraduates

The major efforts made by the government to curb criminality amongst undergraduates as reported by Ailemen (2013) include:

- using the security agencies (especially the police) to arrest, detain and prosecute students identified for involvement in criminality;

- enactment of special Laws and Regulations with stringent punishments against criminals who commit crimes such as: Cultism, Armed Robbery, Terrorism and Kidnapping;

- prohibition of student's union activities in the campuses where such activities are used to perpetrate criminality;

- setting up of special government enquiries to investigate the causes of student's involvement in criminality, and to recommend how to eradicate criminality amongst undergraduates;

- implementation of government white-papers on how to eradicate criminality among students;

- sending of special military taskforce to help curb criminality in the campuses; and

- The approval of employment of security personnel for the institutions security department.

2.2.5.3. Efforts by the Church to Curbe Criminality in Tertiary Institutions

Chukwuemeka (2010) states that Churches in Nigeria have not relaxed over the menace of criminality in Tertiary Institutions in the country. Chukwuemeka (2010) further states that some of the approaches by the Church include:

- Creating Awareness In The Institutions That Jesus Christ Is The Way;

- Church- Planting In The Campuses And Other Areas Where Students Live Mostly To Enable The Students Have Access To Spiritual Counseling;

- The Church Also Advice The Government On How To Handle The Students Of Higher Institutions In Order To Prevent Spoiling The Image Of The Country;

- Organizing Seminars And Other Related Gatherings For Higher Institutions By The Christian Association Of Nigeria (CAN).

\subsubsection{Other Suggested Solutions to the Menace of Crime amongst Undergraduates in Nigeria}

Oguntuase (1999) submits that Higher Education in Nigeria has collapsed and requires urgent attention such as a declaration of a state of emergency in our Educational System. To overcome criminality amongst undergraduates, Oguntuase (1999) advocates the following measures:

- JAMB should only be made to play the role of setting the National Minimum Standard of entry into the higher institutions. Each institution should thereafter be free to admit its own students after their internal screening - this will enable institutions monitor their students closely. Major fallout of this method is that institutions with poor record of performance will lose patronage while secondary schools with low college enrolment of their students will improve their standard or fold.

- Upgrade the facilities in the institutions such as Hostels, Libraries, Bookshops, Laboratories, and Lecture Rooms with appropriate teaching aides. Decongest the schools or raise the staff/student ratio through improved condition of service for the lecturers to such a level that will reverse the brain drain syndrome.

- The members of cult groups should not be discriminated against. In fact, the leadership of these groups should be called upon to work with the management of Higher Institutions towards eradicating crime amongst students.

- Develop a program to monitor and report on the composite academic performance of each cult group and their members and recommend appropriate rewards for academic and moral excellence.

- Put up a program to disarm all cult groups and cause them to surrender their weapons to the authority. Actions should be taken against those who refused to surrender their weapons.

On their part, Ajayi, Ekundayo and Osalusi (2010) recommend the following: 
- The Government and non-government agencies should step up their campaigns against criminality through sensitization, seminars and workshops, symposium, posters, handbills and public lectures.

- Parents should not show support for criminality, they should be more vigilant concerning the activities of their children.

- Moral education should be introduced in all spheres of live especially in educational institutions.

- There must be improved facilities and living conditions on all campuses so as to minimize perceived strain in the social system that underlines criminality in the campuses.

- Sporting activities should be vigorously pursued so as to make universities attractive and involving, so that youthful exuberances of students will find a rewarding outlet in competitive sports like football, athletics, which could engage students in their spare times.

It is disheartening to note that despite these efforts, criminality still persist in Nigeria's Tertiary Institutions. It is based on this that I belief that this ugly situation can be remedied through the application of services marketing, therefore the next topic is on marketing and social causes.

\subsection{Theoretical Framework}

These are topics related to the topic under study and which constitute theories and speculations by scholars. They are mostly reviewed through textbooks. For this study, the major topics reviewed include: meaning of services marketing; marketing mix for services; measuring services quality in tertiary institutions; promotional mix for services marketing; meaning of crime and theories of crime.

\subsubsection{Meaning of Services Marketing}

To explain services marketing, it is important to understand the meaning of marketing. This is because services' marketing is a branch of marketing. The difficulty in defining and understanding marketing is as a result of its controversial nature which is in theoretical and practical forms. In theory, different definitions by different authors are given for marketing, while in practice; adjunct professions of marketing such as advertising, buying, selling, and public relations are termed marketing. As a result, anytime marketing is mentioned, the laymen confuse marketing to mean activities or professions such as buying and selling, advertising, sales promotions, pricing, product planning, market research, retailing and wholesaling. Ogwo (2008) terms these activities adjunct professions of marketing. This confusion in marketing practice continued until the American Marketing Association (1984) as quoted in Jobber (2004) gave a unifying definition for marketing as "the process of planning and executing the conception, pricing, promotion and distribution of ideas, goods and services to create exchanges that satisfy individual and organizational objectives". Based on this definition, Nkamnebe (2003) and Ogwo (2009) in their separate views state that marketing is basically aimed at making exchanges easier and faster by promoting relationships through the identification and satisfaction of customer wants. In their view, Brassington and Pettit (2006) state that 'marketing is to establish, maintain and enhance relationships with customers and other parties at a profit, so that the objectives of the parties are met'. This is achieved by mutual exchange and fulfillment of promises. From a macro point, Perreault and McCarthy (2003) see 'marketing as a social process that directs an economy's flow of goods and services from producers to consumers in a way that effectively matches supply and demand and accomplishes the objectives of the society'.

The implications of these definitions are that two parties are involved in an exchange relationship and that each party is expected to give something in return to the other party. For this study, these parties are tertiary institutions in Nigeria (Marketer) and undergraduates (Customers). To realize the marketing objectives, Kotler and Armstrong (2005), recommend a sequence of activities which include: (i) the marketer must first identify the need/wants of the market and subsequently provide products that would match/satisfy the said need/want; (ii) The marketer should design a customer driven marketing strategy which is preceded by construction of a marketing program that would deliver superior value; and (iii) all marketing effort should be aimed at building profitable relationships and creating customer delight. Marketing offers are not limited to physical offers. They include: Goods, services, experiences, events, personalities, places, properties, idea, organizations and information (Kotler and Keller: 2006). But apart from goods, other forms of products have similar characteristics with service; they are intangibles and their core form the bases for their patronage. As identified earlier, there are several branches of marketing, but services' marketing is most suitable for tertiary institutions. Hence, the need for the explanation of services marketing in tertiary institutions.

It is worthy to note that tertiary institutions in Nigeria are rendering services to their customers. Services are intangible offers that satisfy the needs of customers with the objective of capturing value from them. As a definition, Zeithaml and Bitner (2000) state that 'services include all economic activities whose output is not a physical product or construction, is generally consumed at the time it is produced, and provide added value in forms (such as convenience, amusement, timeliness, comfort, or health) that are essentially intangible concerns of its first purchaser. This definition further clarifies that services have features that distinguish them from goods (tangible products). Palmer (2005) summarizes these features under four headings, namely; intangibility, inseparability, variability and perishability. Services are intangible because they cannot be seen, felt, tested or touched in the same manner that we can sense tangible goods. The inseparability nature of services stems from the fact that production and consumption occur at the same time through an interaction between the producer and the consumer. The variability feature is based on the fact that, the quality of services cannot assume sameness. This is because services are performances frequently rendered by humans. Therefore, no two services will be precisely alike. Also no two customers are precisely alike, and each will have unique demand, or experience the service in a unique way. Services are perishable because they cannot be stored. Therefore, production and consumption are simultaneous. 


\subsubsection{Marketing Mix for Services in Tertiary Institutions}

Because of these features of services stated above, it becomes difficult to apply the traditional four P's (4P's) of marketing (product, price, promotion and place) to services marketing. Kotler and Keller (2006) state that additional three $\mathrm{P}^{\prime}$ 's (Physical evidence, People and Process) are used to accomplish the marketing objectives for services by tertiary institutions. These are briefly examined as follows:

\subsubsection{Product}

Anything offered by the organization to satisfy the need of customers is a product. Other marketing tools are aimed at ensuring that the product is of high quality. The ability of the product to satisfy the customer's needs enhances their patronage. To realize this, there is need to offer variety of services to students to enable them realize their full potentials. For instance, apart from ensuring that students get adequate lectures with appropriate teaching aids, the university management can introduce sporting competitions, Beauty Pageant competitions, quiz or debates, seminars and workshops, etc. These activities should be done on semester basis, and prices with high financial reward be given to outstanding students. This will keep students busy and discourage them from having time for criminal activities.

\subsubsection{Price}

Price is what the undergraduates give, do or pay for the quality services they receive from the institution. Apart from paying their fees promptly without complaint; students will keep to the rules and abstain from criminal activities. There may be need to exercise price discrimination in favor of the law abiding students. Students who get involved in criminal activities may be forced to pay double their fees as fines, while the law abiding students may be given some discounts or offered employment opportunities after graduation.

\subsubsection{Promotion}

These are activities used to communicate the benefits of a service to potential consumers. The major promotional elements that can achieve this as Belch and Belch (2007) state; are: advertising, sales promotion, public relations, personal selling, publicity, direct marketing and internet/interactive marketing. The university authority can sponsor cinemas or film shows within the university environment on weekly basis where the consequences and constituents of undergraduates' criminal involvement are shown. Billboards, handbills and posters with similar messages can be used. Lecturers, religious groups and even students can be encouraged to employ word-of-mouth messages to discourage students from criminal activities, messages carrying the consequences of crime can also be broadcasted through the advertising media such as television, radio, newspapers and magazines.

\subsubsection{Place}

This refers to the ease of access that potential customers have to a service. Students should be given easy and free access to the lecturers, Heads of Departments and even non-academic staff. Increased number of lecturers should be employed to reduce the lecturer-students ratio to at least 1-30. This will enable the university authority to identify and satisfy the needs of the undergraduates easier.

\subsubsection{People}

These are the people (staff) that render the required services to the customers. Because of the inseparability nature of services, the human element (staff) is the most vital element of the marketing mix. In tertiary institutions, every staff is a "part-time marketer" because their actions have a much more direct effect on the output received by customers (students). Acts such as being harsh or unfriendly with students, denying students access to their results etc., can discourage students from being law abiding. A cordial relationship between staff and students makes the staff to be the real change agent that they ought to be.

\subsubsection{Physical Evidence}

These are tangible objects used to prove the ability of an organization to render service. This is used to judge the quality of a service when a purchase decision is to be made. In tertiary institutions, the libraries and laboratories should be equipped with modern textbooks, Journals, Newspapers, Magazines and equipments. More classrooms should be constructed and installed with modern teaching aids, young security personnel should be employed and positioned in strategic positions, etc.

\subsubsection{Process}

Process is a series of actions taken in order to convert inputs to something of greater value. The process therefore needs to be short, efficient and effective. Because students are co-producers of services they consume, the steps taken by staff to render the service need to be reduced to save time and cost.

For the purpose of this study, service marketing is the process of applying the services marketing tools (mix) to capture value from customers (undergraduates) through the identification and satisfaction of customer needs/wants. Constituents of services marketing variables are shown in table 6 below: 


\begin{tabular}{|c|c|c|c|c|c|c|}
\hline $\begin{array}{c}\text { Service Offer/ } \\
\text { Quality (Product) }\end{array}$ & Price & Promotion & Place & People & Process & $\begin{array}{l}\text { Physical } \\
\text { Evidence }\end{array}$ \\
\hline Quality level & flexibility & Advertising & Channel type & employees & $\begin{array}{c}\text { Flow of } \\
\text { activities }\end{array}$ & Facility design \\
\hline $\begin{array}{l}\text { physical good } \\
\text { feature } \\
\end{array}$ & Price level & Public relations & intermediaries & $\begin{array}{l}\text { Recruitment } \\
\text { and training }\end{array}$ & $\begin{array}{c}\text { Number of } \\
\text { steps }\end{array}$ & equipment \\
\hline warrantees & terms & publicity & Outlet locations & $\begin{array}{l}\text { Motivation } \\
\text { and reward }\end{array}$ & $\begin{array}{l}\text { Customer } \\
\text { involvement }\end{array}$ & $\begin{array}{c}\text { Employee } \\
\text { dress and } \\
\text { appearance }\end{array}$ \\
\hline Product lines & $\begin{array}{c}\text { differentia } \\
\text { tion }\end{array}$ & Sales promotion & transportation & $\begin{array}{l}\text { Customer } \\
\text { education }\end{array}$ & & $\begin{array}{c}\text { Other } \\
\text { tangibles }\end{array}$ \\
\hline branding & discounts & Personal selling & Storage & & & \\
\hline packaging & allowances & $\begin{array}{c}\text { Internet/social } \\
\text { media }\end{array}$ & $\begin{array}{l}\text { managing } \\
\text { channels }\end{array}$ & & & \\
\hline accessories & & & exposure & & & \\
\hline
\end{tabular}

Table 6: Constituents of Services Marketing Variables

Source: Zeithaml, V.A. and Bitner, M.J. (2000); Services Marketing: Integrating

Customer Focus across the Firm, $2^{\text {nd }}$ Ed, Boston Burr Ridge, and Irwin Mcgraw-Hill

\subsubsection{Measuring Services Quality in Tertiary Institutions}

Tertiary institutions render services using the marketing mix explained earlier. The quality of services rendered by the tertiary institutions depends on the ability of the services to realize prevention and control of crime among undergraduates. The quality of services by the tertiary institution is high if undergraduates avoid crime, otherwise the quality is low. This is in line with the definition of service quality by Palmer (2005) as the ability to perform or render a service. For this study, services quality can be measured through the following major factors: (a) benefits derived from the services rendered; (b) facilities used to render the services; (c) methods of rendering and the process of receiving such services; (d) promotional tools used to render the service; and(e) attitude of staff that render the services. These factors are linked to the result of research effort by Berry and Parasuraman (1991) which summarizes the factors that can influence customers' assessment of service quality in five dimensions as follows: (a) Reliability; (b) Tangibles; (c) Responsiveness; (d) Assurance; and (e) Empathy.

- Reliability can be determined by the benefits realized by undergraduates from the services rendered by the tertiary institutions. If undergraduates are sure they will realize better benefits from graduating without getting involved in criminal activities, then they will avoid crime.

- Tangibles are physical objects used by tertiary institutions to render quality services. They include modern libraries, conducive class rooms and learning environment, adequate security and moderate fees. With these in place, undergraduates will settle for avoiding crime, but study in the university.

- Responsiveness is the willingness of the tertiary institutions to assist the undergraduates. This can also be achieved through the methods of rendering services to undergraduates by staff and process of receiving such services by undergraduates. These methods could be in the form of delivering lectures orally, giving out notes for undergraduates to copy, asking undergraduates to look for text books to read and make their notes.

- Assurance is the knowledge and courtesy of staff and their ability to convey trust and confidence. This can be achieved through positive attitude by the staff on undergraduates and promotion activities by the tertiary institutions.

- Empathy is the provision of caring, individualized attention by staff to undergraduates. It also includes rewards by tertiary institutions to undergraduates who denounce crime.

\subsubsection{Promotional Mix for Services Marketing}

According to Wells, Moriarthy \& Burnett (2007), the promotional functions in most organizations have before now being dominated by mass-media advertising. Organizations relied primarily on their advertising agencies for guidance in nearly all areas of marketing communication. Other promotional and marketing communication tools such as sales promotion, direct marketing, public relations, publicity and personal selling were viewed as auxiliary services. However, Belch and Belch (2007) identify that organizations have recently realized the need to integrate all the promotional mix elements. This is because there are varieties of ways customers can come into contact with an organization or brand. These contacts can range from simply seeing or hearing an advert for a brand to actually having the opportunity to use or experience a brand at an organization-sponsored event. A combination of the various promotional mix elements is called integrated marketing communication (Nnedu 2000). Belch and Belch (2007) state that integrated marketing communication management involves the process of planning, executing, evaluating and controlling the use of the various promotional mix elements to effectively communicate with target audience. The implication of this is that the marketer must consider which promotional tools to use and how to integrate them to achieve marketing and communication objectives.

Promotion according to Anyanwu (2003) is the coordination of all seller initiated efforts to set up channels of information and persuasion in order to sell goods and services or promote an idea such as crime prevention and control. Supporting this view, Nnedu (2000) states that though implicit communication occurs through the various elements of the 
marketing mix, most of an organizations' communication with the market, take place as part of carefully planned and controlled promotional program. The basic tools used to accomplish an organization's communication objectives are according to Belch and Belch (2007) often referred to as the promotional mix. These promotional mixes are: Advertising, Direct marketing, Interactive/Internet Marketing, Sales Promotion, Publicity/Public Relations and Personal selling. The promotional mix is represented in figure 1 below.

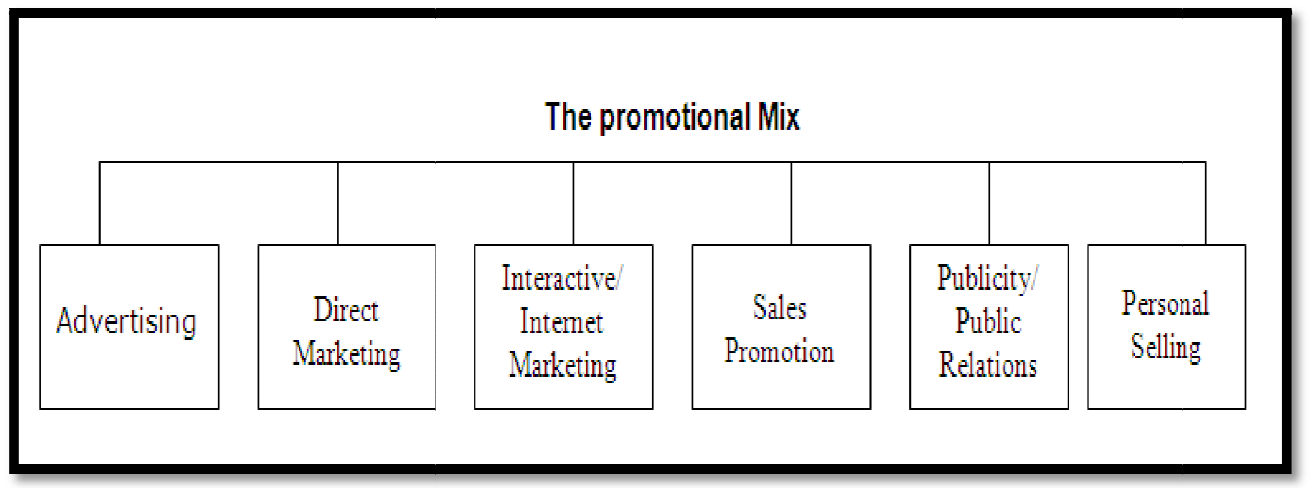

Figure 1: Elements of the Promotional Mix

Source: Belch And Belch (2007); Advertising and Promotions: an Integrated Marketing Communication Perspective, $7^{\text {th }}$ Ed, Boston Burr Ridge, Mcgraw-Hill Irwin

\subsubsection{Advertising}

Borrowing from Wells, Moriarthy and Burnett (2007), Advertising is any paid form of non-personal communication about an organization, product, service or idea by an identified sponsor. The implications of this definition are:

- Advertising must be paid for. This reflects the fact that the space or time for an advertising message generally must be bought, except for public service announcements or messages sponsored by the government to promote an idea or change behavior by the media.

- The non-personal component means that advertising involves mass media (such as Television, Radio, magazines, Newspapers, Bill Board, Point of purchase, Outdoor and others.) that can transmit message to large groups of individuals, often at the same time. There is generally no opportunity for immediate feedback from the message recipient (except indirect response advertising). Therefore, before the message is sent, the advertiser must consider how the audience will interpret and respond to it.

The importance of advertising is for reaching first; this means that it is the most cost-effective way to reach large audience in a shortest time. Secondly, it is a valuable tool for building organizational image and or brand equity. This is because it does not only provide information; it also influences the perception of consumers. Thirdly, advertising stimulates' demand, and the adoption process of an idea. This is occasioned by the low cost of repeated advertising in various media.

\subsubsection{Sales Promotion}

Sales promotions have varied connotations. But deducing from the legion of definitions, Okpara, Anyanwu and Iyanga (1999) define sales promotions as "encapsulates all the short term promotional arrangements and inducements aimed at consumers, sales force and or middlemen to ultimately create or reinforce favorable market response towards products. Products here represent an offer (goods, services, ideas, personality, etc.) for which its acceptance by the target adopter, audience or market is sought".

For this study, a sales promotion entails the offer of incentives that would encourage the target adopters (undergraduates) to stop or avoid crime. Clark (1997) Identifies that some of the incentives that have been used by government and management of tertiary institutions to discourage undergraduates from committing crimes are:

- Offer of scholarship for post graduate studies;

- Offer of automatic employment after graduation;

- Exemption from certain fees, or permitted to pay less fees;

- Offer of administrative positions in student's union government;

- Offer of free accommodation within the institution's environment; and Provision of personal security for students that publicly repented and willing to assist the institution prevent and control crimes among undergraduates.

- The essence of these incentives is to realize the main objective of this study which is to prevent and control crime among undergraduates.

\subsubsection{Public Relations}

Good image is the main reason for realizing an everlasting exchange which modern marketing is aimed at. Okpara (2002) adds that public relations are all about favorable image or impressions in the eye and mind of various relevant publics, both within and outside an organization. Summarizing a litany of definitions, The British Institute of Public

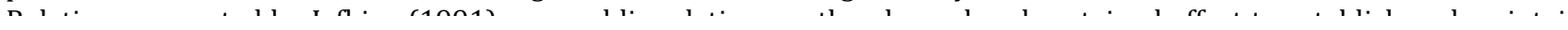


goodwill and mutual understanding between an organization and its publics. The emphasis here is publics. Again, Jefkins (1991) defines publics as those persons or groups whose actions directly impact or affect the operations or activities of an organization. For tertiary institutions, undergraduates, staff, parents, government or owners of the institution, and suppliers is publics to the institutions. For our study, the undergraduates are the main publics because the emphasis of this study is prevention and control of crimes among undergraduates.

A critical look at the definition by the British Institute of Public Relations reveals that Public Relations is a planned activity that follows a system and not done haphazardly. It also requires a two way communication as it emphasizes mutual understanding between the parties concerned. But to give a practical approach to how public relations in tertiary institutions work, the public relations news of New York (1947) is adopted. According to the News, Public Relations (PR) is a management function which evaluates public attitudes, identifies the policies and procedures of an individual or organization with the public interest, and plans and executes a programme of action to earn public understanding and acceptance. Public relations uses publicity and a variety of other tools such as special publications, participation in community activities, fund raising, sponsorship of special events and various public affairs activities to enhance an organizations' image. Examples of public relations activities executed by tertiary institutions as identified by Onyeke (1999) are:

- Using institutions internal magazines to publish efforts of the institutions aimed at assisting the students;

- Sponsoring of internal (departmental) sporting activities with huge financial rewards to winners;

- Sponsoring students to sporting activities outside the institution e.g. (nuga);

- Sponsoring students essays, or quiz and science/technology competitions and exhibitions both locally and overseas;

- Donation of vehicles, furnished offices and accommodation, and budgetary allocations to student's union government;

- Sponsoring of trade fairs, shows and exhibitions in the institutions where students are used as sales persons to the organizations;

- Donation of cafeteria, restaurant and bars where foods and drinks are sold to students at subsidized prices;

- Sponsoring of social activities such as most beautiful girl or most handsome boy in the institutions with attractive rewards attached to the context;

- Building and donating sports and recreation facilities to students; and

- Donating free buses to ease student's transportation problems.

\subsubsection{Publicity}

According to Onyeke (1999), Publicity refers to non-personal communications regarding an organization, goods, service or idea under identified sponsorship. It usually comes in the form of a news story, editorial, or announcement about an organization and/or its products and services or idea. Okpara, Anyanwu and Iyanga (1999) add that like advertising, publicity involves non-personal communication to a mass audience, but unlike advertising, publicity is not directly paid for by the organization. The organization attempts to get the media to cover or run a favorable story on a product, service, idea, or event to affect awareness, knowledge, opinions, and/or behavior. Techniques used to gain publicity include:

- News releases

- $\quad$ Press conferences

- Feature articles

- Photographs

- $\quad$ Films and videotapes

Publicity has the advantage of credibility over other forms of promotion.

\subsubsection{Personal Selling}

According to Futrell (2006), Personal selling is a form of person-to-person communication in which a seller attempts to assist and/or persuade prospective buyers to purchase the organizations product or services or to act on an idea. Unlike advertising, personal selling involves direct contact between buyer and seller, either face-to-face or through telecommunication device such as G.S.M. Handsets, telephone. This interaction gives the marketer communication flexibility, the seller can see or hear the potential buyers reactions and modify the message accordingly. The personal individualized communication in personal selling allows the seller to tailor the message to the customer's specific needs or situation.

Furthermore, Dunne and Lusch (1999) add that Personal selling also involves more immediate and precise feedback because the impact of the presentation can generally be assessed from the customer's reactions. If the feedback is unfavorable, the marketer can modify the message. This can be easily realized through the interaction between the academic staff and the undergraduates. In fact, despite the positive contribution of the synergy among all staff, the academic staff of every institution should be the actual change agent for crime prevention and control among undergraduates. This is because; the academic staffs have the most frequent contact-point with the undergraduates who are the target adopters. It is based on this that Palmer (2005) states that every staff of a service providing organization such as tertiary institution is called 'a part-time marketer'. This is because the actions of the staff (academic staff) have a much more direct effect on the output received by the customers. This also makes it essential that service organizations 
such as tertiary institutions clearly specify what is expected from the change agents (academic personnel) in their interaction with the target adopters (undergraduates).

\subsubsection{Direct Marketing}

Tapp (1998) defines Direct marketing as a form of promotion in which the organization communicates directly with target customers to generate a response and or a transaction. It involves a variety of activities including database management, direct selling, telecom marketing, and direct response adverts through direct mail, the internet and various broadcast and print media. In their contribution, Kotler and Keller (2006) state that direct marketing involves an individualistic approach to responding to target customer needs. This means that the organization will spend huge sums of money developing and maintaining databases containing the addresses and/or phone numbers of present and prospective customers. It also involves the use of telemarketing to call target adopters directly and attempt to sell to them the ideas or qualify them as sales leads. This magic can be achieved by using the Registrar's office or the student's affairs department of the institution to keep computerized data including photographs of all students of the institution. This will enable the institutions or security agencies interact directly with a targeted undergraduate with the aim of preventing or controlling his involvement in crimes.

\subsubsection{Interactive/Internet Marketing}

Belch and Belch (2007) define Interactive/internet marketing as a form of promotion that involves a back-and forth flows of information whereby users can participate in and modify the form and content of the information they receive in real time through the internet. It allows users to perform a variety of functions such as receive and alter information and images, make inquiries, respond to questions and of course make purchases. In addition to the internet, Mason and Perreault (2002) state that other forms of interactive media include CD Roms, Kioks, Interactive television, and digital cell phones. The interactive medium that is having the greatest impact on marketing is the internet. The internet is actually a multifaceted promotional tool. On one hand, it is an advertising medium as many companies or organizations advertise their products on the websites of others or pay to link their websites to search enquires such as Google and Yahoo. The internet can also be viewed as an effective marketing communication tool in its own right as it is a medium that can be used to execute all of the elements of the promotional mix. The interactive nature of the internet is its major advantage. In this modern world, every undergraduate own a mobile G.S.M handset, as a result they are hooked to the internet on 24 hourly bases. Undergraduates do more browsing than conventional reading, thus making the interactive/internet marketing to be an efficient means of communication between the change agents and the target adopters.

\subsubsection{Meaning and Theories of Perception}

Perception is one of the psychological factors that affect an individual's behavioral change as a result of exposure to stimuli. It is the process of acquiring information or knowledge about the surrounding environment or situation through the senses. It is the ability or attempt to make sense (meaning) out of the stimuli to which we are exposed (Perner: 2010). It is worthy to note that such stimuli must be something of interest to the individual otherwise the information will be meaningless. The major factors that influence an individual's perception are exposure, attention and interpretation (Blank: 2010).

- Exposure involves the extent to which an individual encounters' a stimuli. For example, an undergraduate is exposed to promotion activities that discourage crime among undergraduates through leaflets, Radio adverts, signposts or billboards and even staff or friends. Seeing these promotional activities once (a single exposure) may not actually attract the undergraduate's attention. This is because the said undergraduate may have not planned to see such messages. A repeated exposure of the undergraduate to the said message severally and through several media will attract the attention of the undergraduate provided the message is such that is capable of attracting the undergraduate's interest and there is no noise (distraction) at the time of the message.

- Attention means picking interest in the message seen or exposed to. Attention also leads to interpretation. The undergraduate's attention is drawn when he/she takes time to read or study the said message or even discuss it with other undergraduates.

- Interpretation means making sense out of the stimuli (message carrying the consequences of crime). If the undergraduate beliefs in the message, his behavior is likely to change (to abstain from criminality). These explanations are similar to the representation in figure 2 below. 


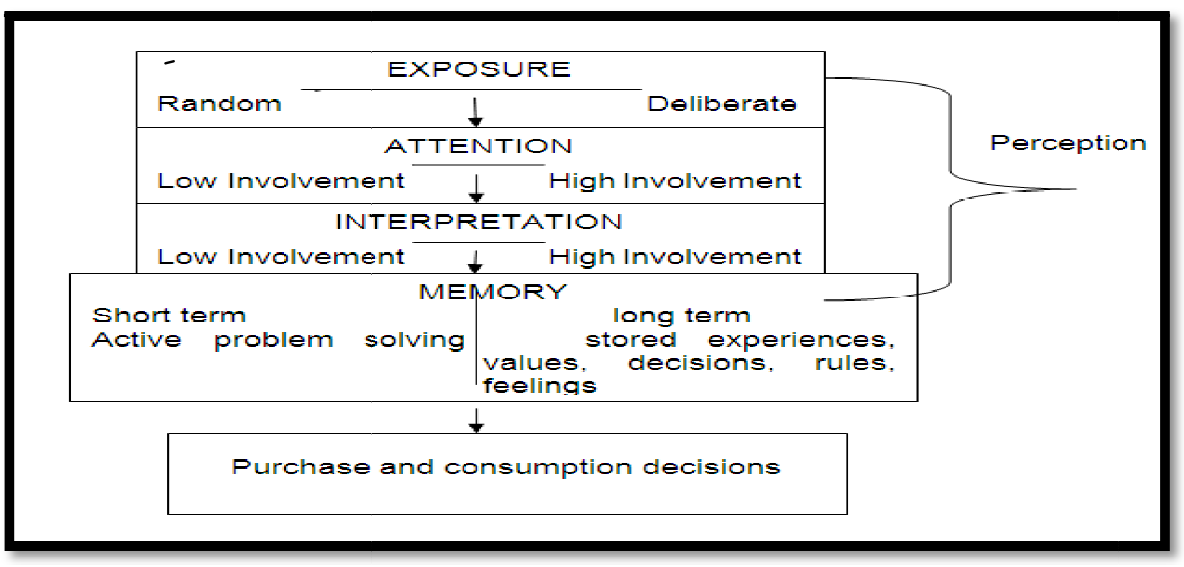

Figure 2: Information Processing for Decision Making

Adopted from Hawkins, Best, and Coney (2001); Consumer Behavior: Building Marketing Strategy, $8^{\text {th }}$ ed. Boston Burr-Ridge Irwin McGraw Hill.

Hawkins, Best and Coney (2001) state that information processing is a series of activities by which stimuli are perceived, transformed into information, and stored. The diagram in figure 1 shows a useful information processing model having four major steps namely: exposure, attention, interpretation and memory. The first three (exposure, attention and interpretation) constitute perception.

\subsubsection{Perception and Behavioural Changes}

Belch and Belch (2007) see perception as the process by which an individual receives, selects, organizes, and interprets information to create a meaningful picture of the world. Perception is an individual process because it depends on internal factors such as a person's beliefs, experiences, needs, moods, position and expectations. The perceptional process is also influenced by the characteristics of a stimulus (such as its size, color, and intensity) and the context in which it is seen or heard such as advertising messages on radio, billboards, posters and magazines. It is therefore important for universities to identify the appropriate stimulus that is capable of attracting the undergraduates' attention. The importance of this is that once an undergraduate selects and attends to a stimulus, the perceptual process focuses on organizing, categorizing and interpreting the incoming information (O'Shaughnessy:1992).Furthermore, Cravens and Piercy (2003) state that selectivity of information occurs throughout the various stages of consumers' perceptual process depending on the stimuli used. Based on this, Belch and Belch (2007) state that selective perception may occur at the exposure, attention, comprehension and retention stages of perception. This is called selective exposure, selective attention, selective comprehension and selective retention.

Selective exposure occurs if an undergraduate chooses to hear or watch a program aimed at prevention and control of crime among undergraduates. An example is attending crusades or cinemas to watch the consequences of criminality among undergraduates.

Selective attention occurs when the undergraduate chooses to focus attention on certain stimuli while excluding others. An example is where the undergraduate in the cinema watches only how cultists attend parties and attacked their enemies. But when it got to a point where such cultists where arrested by the Police and sentenced to death or prison, the undergraduate will stop watching and move out of the cinema hall.

Selective Comprehension is interpreting information on the basis of one's 'own attitude, belief, motive, experience or position. An example is when a notorious cultist is killed by the Police, other cultist present will switch their interest to something else. But if a notorious cultist is mentioned as a Richman, other cultists present will be interested in the news. Selective Retention means that undergraduates do not remember all the information they see, hear or read even after attending to or comprehending I t. This requires that messages carrying the consequences of crime must be repeated regularly with stimuli that are of interest to the undergraduates. The diagrammatic representation of selective perception process is shown in figure 2 below.

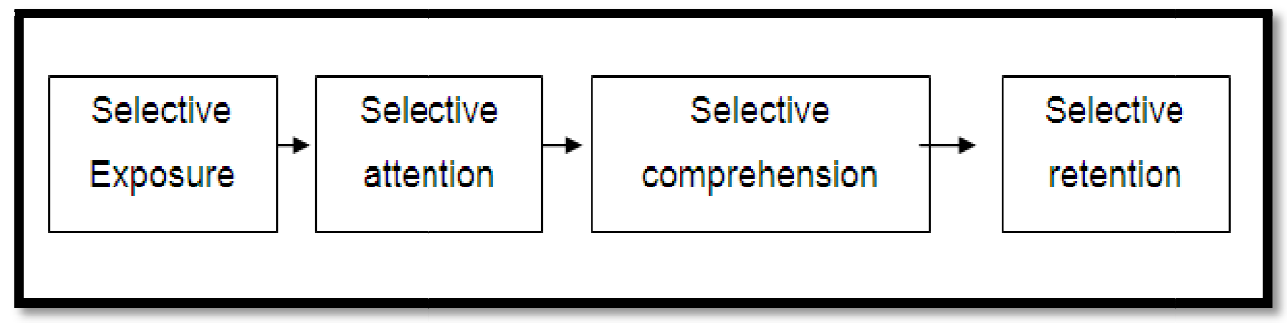

Figure 3: The Selective Perception Process

Source: Belch And Belch (2007); Advertising and Promotion: An

Integrated Marketing Communications Perspective, $7^{\text {th }}$ Ed Boston Burr Ridge, Mcgraw-Hill Irwin 


\subsubsection{Meaning of Crime}

Crime is any act against the Law of a place which attracts punishment. Bursik and Grasmick (1993), state that the branch of law that studies crime is called Criminal Law. On their part, Okonkwo and Naish (2009) state that in Nigeria Criminal Law, Crime and Offence are used interchangeably, while deviance is mostly used in Sociology or Civil Law. Therefore, Crime and Offence mean the same. They further state that offences in criminal laws affect the interest of the state generally and attract punishments such as fine, imprisonment or death. While in Civil Law, deviant behavior or offences only affect the person instituting the charge and mostly attracts fines or forfeiture of property.

\subsubsection{Definition of Crime/Offence}

Section 2 of the Criminal Code Act CAP 77 laws of the Federation of Nigeria (1990), defines a crime as "an act or omission which renders the person(s) doing the act or making the omission liable to punishment under this Code or under any Act or Law". The implication of this definition is that for an Act to constitute an offence, that act and its corresponding punishment must be contained in an existing Criminal Law. In Nigeria, examples of Criminal Laws are: Criminal Code Act, Penal Code, Robbery and Firearms Special Provision Act, Money Laundering Act, Kidnapping and Human Trafficking Act and Electoral Act, etc. It is worthy to note that the variations in punishments attached to these offences are also used in differentiating these offences into; Felonies, Misdemeanors and Simple offences. This is as contained in section 3 of the Criminal Code. Felonies attract punishments of death or imprisonment of not less than three (3) years. Examples of such offences are: Armed Robbery, kidnapping, Murder, belonging to Unlawful Society, Cultism, Rape, Rioting, Stealing, etc. Misdemeanors attract punishment of less than three (3) years but not less than six (6) months, examples are Assaults, Malicious Damages, Unlawful Assembly, etc. While Simple Offences attract imprisonment for less than six (6) months, examples are Traffic Offences, etc.

\subsubsection{Parties to an Offence}

Another relevant point to note here is that most times, undergraduates get involved in crime unknowingly. And because they do not know the constituents of crime, some of them commit crime believing they are only exercising their Fundamental Human Rights, while others commit crime while trying to help their friends. But the Criminal Law identified those that are parties to offences. By so doing, Sections 7 (a) (b) (c) (d) and 10 of the same Act, categorizes parties to offences into: (i) principal offenders and (ii) accessories after the fact.

- $\quad$ Principal offenders: Section (7) of the Act states that when an offence is committed, each of the following persons are deemed to have taken part in committing the offence and to be guilty of the offence, and may be charged with actually committing it. That is to say:

$>$ every person who actually does the act or makes the omission which constitutes the offence;

$>$ every person who does or omit to do any act for the purpose of enabling another person to commit an offence;

$>$ every person who aides another person in committing the offence; and

$>$ any person who counsels or procures any other person to commit the offence.

- Accessories after the fact: Section (10) of the same Act states that a person who receives or assists another who is to his knowledge guilty of an offence in other to enable him/her escape punishment is said to be an accessory after the fact. The only exception here is husband and wife of Christian marriage. This is because, the same Section 10 states that a wife does not become an accessory after the fact to an offence which her husband is guilty by receiving or assisting him in other to enable him escape punishment; nor by receiving or assisting in her husband's presence and by his authority, another person who is guilty of an offence in the commission of which her husband has taken part, in order to enable that other person to escape punishment, nor does a husband become accessory after the fact to an offence which his wife is guilty by receiving or assisting her in order to enable her escape punishment, and that the husband and wife must be of Christian marriage. Section 1 of the Criminal Code Act CAP 'C38' Laws of the Federation 2004 defines Christian marriage to mean a marriage which is recognized by the place where it is contracted as the voluntary union for life of one man and one woman to the exclusion of all others.

From the definition of crime, it could be deduced that criminality is exhibiting a criminal character or quality, or having the tendency to commit crime. Having known the meaning of crime, let us identify the nature of criminality amongst youths in Tertiary Institutions.

\subsubsection{Theories of Crime}

Before discussing the nature of criminality amongst undergraduates in Tertiary Institutions, it is pertinent to understand the meaning of Tertiary Institutions. This will actually act as a guide to realizing the objectives of this chapter and at the same time direct our focus to obtaining the needed secondary data for this study.

\subsubsection{Meaning of Tertiary Institution}

Redmond (1998), states that Tertiary Institutions mean institutions beyond a secondary school level. It is also called Higher Institution or Institution of Higher Education. It includes not only Universities and Colleges, but also professional schools in such fields as Law, Theology, Medicine, Business, Music, Art, etc. A major characteristic of these institutions is that at the end of a prescribed course of study, a Degree, Diploma or Certificate is awarded.

To further explain the meaning and essence of Higher Education, the United Nations Education, Scientific and Cultural Organization (UNESCO) declaration of (2009), states that the mission of Higher Education includes: 
- To serve the human person and society;

- To direct and shape the society's path to the future through research, training and cooperative activities with various social actors;

- To solve major global regional and local problems such as poverty, hunger illiteracy, social exclusion, etc.;

- To help students acquire knowledge, skills, attitudes, values and abilities that will enable them act as responsible and committed citizens.

- To preserve and assert cultural identify, promote the propagation and creation of cultural values, and to encourage cultural diversity.

Stones (1979) states that a Higher Institution is expected to execute three basic functions, namely: (i) to impact manpower skills; (ii) to contribute to national and international dialogue and criticism; and (iii) to act as center for research. To realize these, Jibril (2007) opines that a Higher Institution is expected to organize the communication of knowledge. Knowledge is developed through learning. It enables a highly organized world to cope with complex social changes and contemporary challenges.

Given the essence and mission of tertiary institution and also the consequences of criminality as explained earlier, one will begin to wonder if students in Tertiary Institutions would ever have the opportunity of indulging in criminality. Unfortunately, the rate of student's involvement in criminal activities in Nigeria is very alarming. This is evidenced through an avalanche of reports of criminality amongst students in Nigeria Tertiary Institutions as presented in figure 2.1.1.

From the sociological point of view, crime and deviance behavior are interchangeably used. Based on this, Theo (1998) defines deviance as an act considered by public consensus or the powerful at a given time and place to be a violation of some social rule. The deviant acts studied under this definition are categorized under criminal deviance such as homicide (murder), robbery, rape, drug abuse and non-criminal deviance such as homophobia, using pornography and mental disorder. Furthermore, most scholars other than sociologist generally attribute deviance to a certain biological or psychological abnormality in the individual. But sociologists have long assumed that there is nothing physically or mentally wrong with most deviants. Based on this, Theo (1998) articulates the causes of deviance behavior under the following theories: Functionalist Theory, Merton's Strain Theory, Control Theory, Shaming Theory, Conflict Theory, Relative Deprivation Theory and Differential Association Theory. These are briefly explained as follows:

\subsubsection{Functionalist Theory}

This theory states that people commit crime because they belief that criminal activities contribute to the socioeconomic development of the society. A good example is where students destroy and loot residences and properties of politicians believed to have stolen government properties. To prove this theory, Emile Durkheim as quoted in Theo (1998), debunks the claim that deviance is always harmful, but contributes to social order and brings benefits to the society if it occurs within limit.

\subsubsection{Merton's Strain Theory}

This theory is popularly called the theory of "anomie". It believes that people commit crime because they do not have access to legitimate means of realizing their goals or achieving success as expected of them by their family members or the larger society. In propounding this theory, Robert Merton (1930) as quoted in Theo (1998), states that "anomie" is a social condition in which norms are absent, weak or in conflict, and may arise when there is inconsistency between the cultural goals and the institutionalized (socially approved or legitimate) means of achieving these goals. Because undergraduates believe they cannot get jobs after graduation or receive praises from parents and other relations if they don't make good results such as 2.1 grade despite the fact that adequate lecturers and teaching aids are not provided, they resort to committing crime as a source of money that could be used to realize their goals.

\subsubsection{Control Theory}

This theory states that people commit crime because there is weak control over them by their families or the social institutions where they belong. Travis Hirsch (1969) as quoted in Theo (1998) states that the family, school and other social institutions can greatly contribute to social order by controlling deviant tendencies. And that when such is lacking or weak, people will commit crime. Therefore, when parents disregard the change in behavior of their undergraduate children, or when lecturers over look undergraduates' attendance to classes or even accept gratification from them to award undeserved marks, they are encouraging the students to commit crime.

\subsubsection{Shaming Theory}

This theory claims that people commit crime in retaliation against the society for rejecting or ostracizing them as a result of their past criminal records. The proponent of the shaming theory, John Braithwaite (1989) as quoted in Theo (1998) states that Shaming involves an expression of disapproval designed to evoke remorse in the wrong doer. Therefore, out of shame, people commit more crime. It is therefore advisable to show forgiveness and acceptance on wrong doers rather than stigmatizing them. Those who denounce crime publicly should be rewarded and reintegrated to boast the morale of others to repent.

\subsubsection{Conflict Theory}

This theory is of the view that people commit crime because of the oppressive nature of leadership by the political class especially in a capitalist Economy where labor exploitation is high. The proponents; William Chambliss (1969) and 
Richard Quianiey (1974) as quoted in Theo (1998), concludes that the legal authorities favor only the rich and powerful against the poor and weak and that what the authorities defined as crime are only those acts done by the poor which may be against the survival of the capitalist system. That to compel compliance from the poor, the authorities cut labor cost and create unemployment. That these unemployed persons are compelled to commit crime so as to survive. Therefore, for fear of unemployment after graduation, undergraduates resort to criminal activities.

\subsubsection{Relative Deprivation Theory}

This theory is of the view that crime is committed by persons when they feel they are unable to achieve their high aspirations. Supporting this view, Theo (1998), states that this behavior develops when one is comparing himself with another, especially when there is wide economic disparity existing amongst persons within the same society. For instance, students commit crime to enable them buy cars because they see their fellow students driving cars in the campus.

\subsubsection{Differential Association Theory}

The message of this theory is that deviance (criminal) behaviors are learnt through interactions with others especially criminals. The proponent Edwin Sutherland (1939) as quoted in Theo (1998), defines differential association as a process of acquiring through interaction with others an excess of definition favorable to violation of law over definitions unfavorable to violation of law. This conforms to the saying: "Show me your friends and I tell you who you are". Parents must know the type of friends their children keep.

\subsection{Conceptual Framework}

This section contains the review of thoughts or imagined abstract of other scholars which are related to the topic under study. They also contain some relevant models. Major topics discussed under this section are: models for analyzing the behavior of undergraduates; suggested model for crime prevention and control among undergraduates using services marketing tools.

\subsubsection{Models for Analysing the Behaviour of Undergraduates}

A model according to Agbonifoh, Ogwo, Nnolim and Nkamnebe (2007), is simply " a representation of some or all of the properties of a larger system". This means that a model is like a mirror that shows what is placed before it. It is an imagination of a real situation. It is a relevant instrument in studying and predicting human behavior. This is because human beings change constantly, thus making prediction about it difficult. The major reason why measures taken in the past to curb criminality among undergraduates refused to yield the needed fruit is the inability of the change agents to identify the need-satisfying ability of the campaign for crime prevention and control among undergraduates. To achieve the objective of every social marketing activity such as crime prevention and control among undergraduates, Kotler and Roberto (1989) recommend that the social change product should have the ability to predict how target adopters (undergraduates) will behave when they are exposed to social change campaign. Hawkinns, Best \& Coney (2001), state that this prediction requires knowing how to determine the behavior of target adopters (undergraduates). As soon as the behavior is determined, the campaign can start.

For our study, an undergraduate has adopted to avoid crime when he or she beliefs that crime will lead him/her to death or imprisonment (as punishment). This belief is converted to an attitude when the student starts avoiding crime because he/she beliefs crime will destroy his future. This attitude will become a value when the student beliefs that crime would destroy the economic development of our country and advices everybody to avoid crime. By so doing, a social marketer's task should include converting a non- belief into a belief, a belief into an attitude or an attitude into a value. The success of these changes in behavior could be based on different reasons. These reasons according to Kotler and Roberto (1989) include:
- Compliance
- Identification
- Knowledge
- Internalization

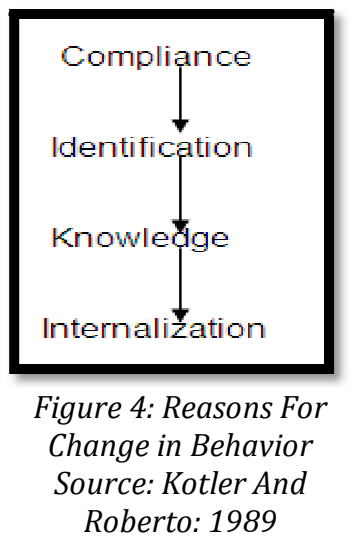


Using criminality amongst students in tertiary institutions for instance, students may decide to avoid crime because government passed laws to secure compliance (Compliance adoption). Others may avoid crime because people they admired (reference groups or opinion leaders) and their peer group have publicly denounced crime (identification adoption). Others may decide to avoid crime because they belief it is a reasonable adjustment under a new circumstance or based on ugly experiences they had in the past for committing crime (knowledge based adoption). Why others may decide to avoid crime because they belief it is the right thing to do: maybe they are about graduating or getting older (Internalization adoption).

\subsubsection{Adoption Models for Undergraduates}

It is based on these types of adoption that social marketers developed four different models of how target adopters can be moved to the final decision to adopt an idea, behavior, or tangible product. These models according to Kotler and Roberto (1989) are:

- Learn- feel-do adoption

- Do-feel-learn adoption

- Learn-do-feel adoption

- Multipath adoption

The position of these adopters behaviors are shown in figure 4 below:

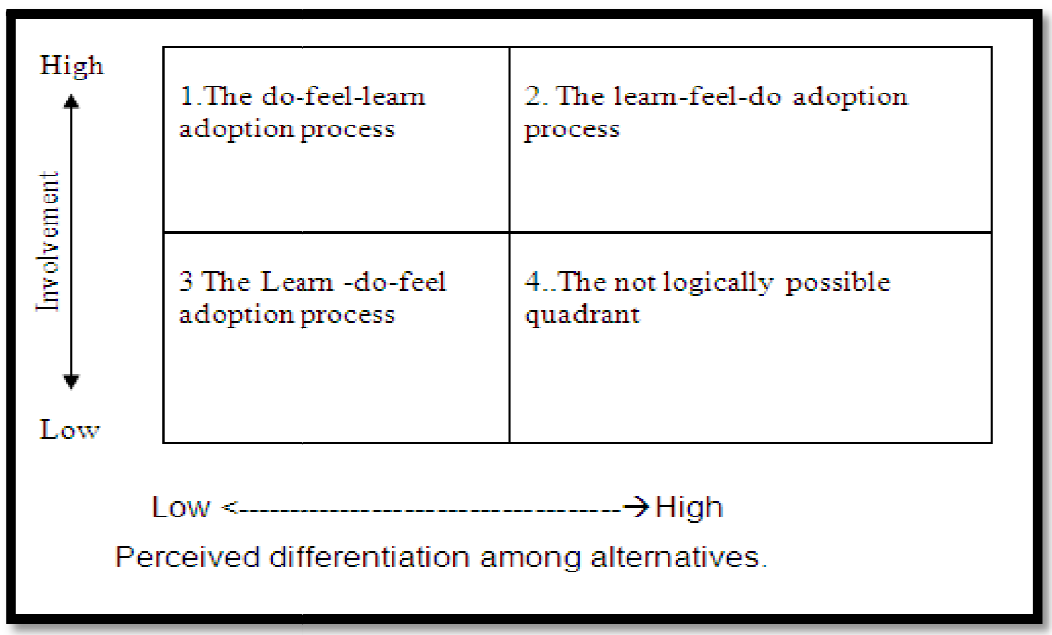

Figure 5: Adoption Models for Undergraduates

Source: Kotler and Roberto (1989:95); Conditions for Selecting Adoption Process Models

Let us briefly discuss this models and how they affect our study.

\subsubsection{Learn-Feel-Do Model}

In this model, undergraduates' involvement in the campaign for crime prevention and control among them is high. They are also exposed to many alternative social change campaigns. This is represented in quadrant 2 of figure 2.4.This means that undergraduates are first made to be aware of the consequences of crime through various promotional tools, they learn to pick interest, and then start practicing the campaign of crime prevention and control among undergraduates.

\subsubsection{Do-Feel-Learn Model}

In this model, undergraduate's involvements in the campaign against criminality are also high but have low perceived differentiations among alternatives. It is a reverse of the normal learning process. It states that the undergraduates will stop criminality temporarily because of the perceived benefits of avoiding crime which they are offered or already enjoying. By so doing, they will learn a lot about crime prevention and control among undergraduates. This is represented in quadrant 1 of figure 4

\subsubsection{Learn-Do-Feel Model}

In this model, undergraduates' involvement in the crime prevention and control model is low, and they also have low perceived differentiations among alternatives.Here,the undergraduate select or practices the campaign which they are familiar with (such as messages on bill boards within the institutions), and based on perceived benefits, they give a weak trial. This means that the undergraduates can easily drop their weak decision and go back to criminality because of weak satisfying experience. The model is represented in quadrant 3 of figure 4. 


\subsubsection{Multipath Process (Not Legally Possible)}

This model synthesizes the other models. From the quadrant, the undergraduates' involvement is week, but he /she is exposed to alternative social products. It states that undergraduates will be exposed to many crime prevention and control campaigns, then they will have the option of either enjoying the benefits of avoiding crime before avoiding crime, or first suffering the consequences of criminality before avoiding crime to enable them enjoy the benefits of avoiding crime. The model is represented in quadrant 4 of figure 4.

\subsection{Suggested Model for Crime Prevention and Control among Undergraduates in Nigeria}

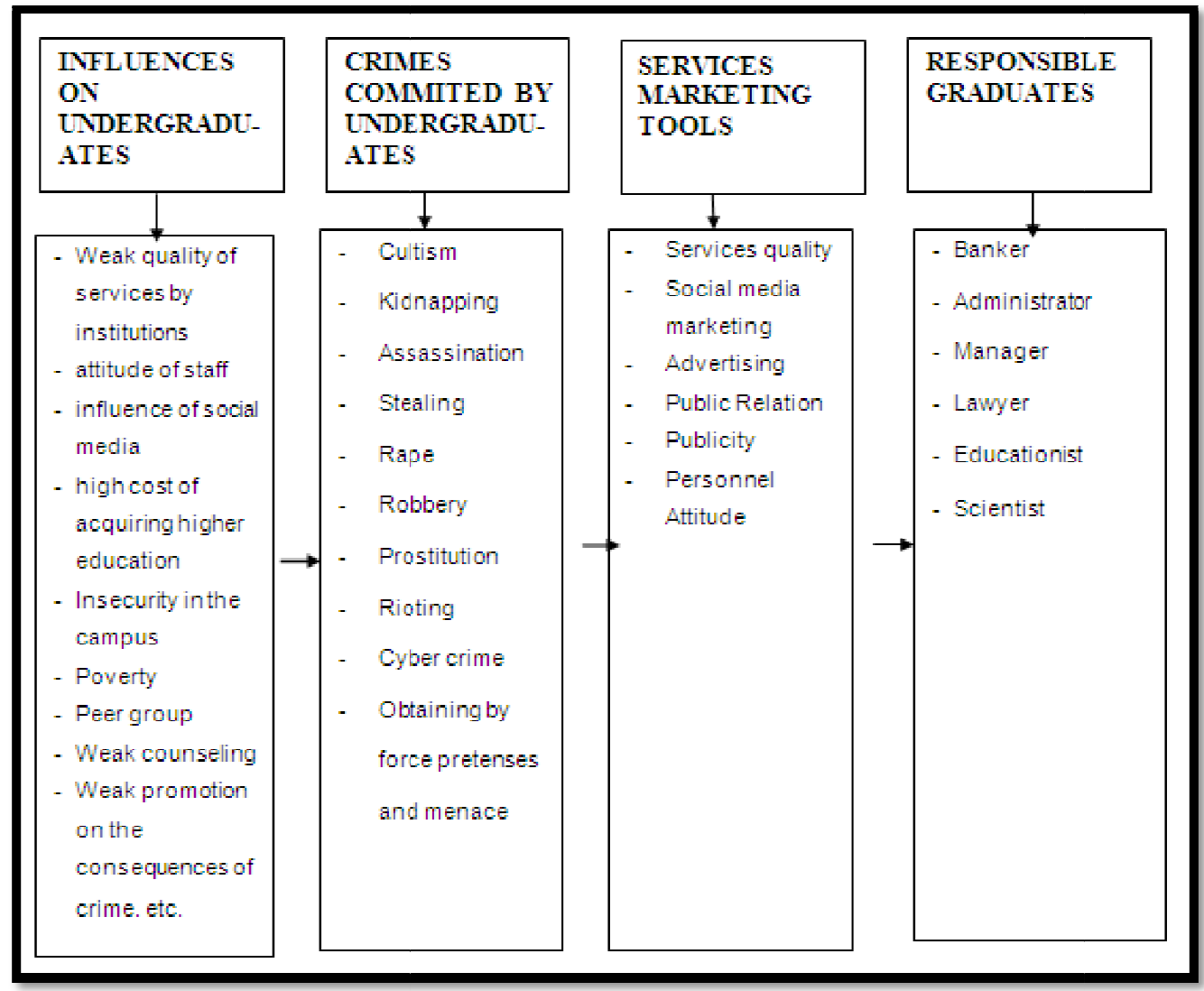

Figure 6: Suggested Model for Crime Prevention and Control among Undergraduates Using Services Marketing Tools

Source: Researchers Desk (2013)

From the diagram, an undergraduate with higher aspirations gains admission into a tertiary institution in Nigeria. From the point of entry, he/she starts experiencing weak services delivery as a result of corruption by staff of the institution, unfriendly staff behavior, high cost of acquiring higher education, poverty, insecurity in the campus, peer group influence, weak counseling and weak knowledge of the consequences of crime. Furthermore, because of negative information from the social media, poverty, greed, poor parental upbringing and fear of unemployment after graduation, the undergraduate becomes a monster dreadful to himself, the institutions and the society at large by practicing criminal activities such as cultism, kidnapping, armed robbery, assassination, stealing, prostitution, rioting, examination and electoral malpractices. But when the undergraduate is exposed to services marketing activities through quality education services and marketing communication tools aimed at preventing and controlling crime among undergraduates, the undergraduate who had earlier turned to a monster will denounce criminality and graduate to become professionals such as Bankers, Administrators, Engineers, Lawyers, Consultants and many more. The activities of these professionals will in turn contribute to the social-economic development of the country.

\subsection{Summary of Review of Related Literature}

This chapter started with the definition and explanation of crime by utilizing the provisions of Section 2 of the Criminal Code Act CAP 77, Laws of the Federation of Nigeria. This led to the identification of various crimes commonly committed by undergraduates in Nigeria tertiary institutions to include: armed robbery, cultism, kidnapping, assassination, rape, rioting, stealing, examination and electoral malpractices. Apart from the colossal loss of life and properties, undergraduates suffer long years of imprisonment for their involvement in criminal activities. The reasons for undergraduates' involvement in criminal activities were identified through the theories of crime and media reports. The measures taken to curb criminality among undergraduates by tertiary institutions management, government and even the 
undergraduates, I suggest the use of service marketing tools for crime prevention and control among undergraduates in tertiary institutions. Based this, the meaning of marketing and service marketing were briefly explained. Also reviewed were the meaning of services quality, marketing promotions or communication tools and the models for understanding the behavior of target adopters (undergraduates). The chapter ended with a theoretical framework developed by the researcher.

\section{Research Methodology}

\subsection{Preamble}

This chapter explains the procedure for gathering data for the study. It also explains the scientific method for processing and interpreting data obtained for the study. These are highlighted under the following headings: research design, area of study, population of study, determination of sample size, sampling technique, sources of data, instrument for data collection, administration of research instrument, method for validity and reliability test, techniques for data analysis and hypotheses testing.

\subsection{Research Design}

Given the purpose of this study which is to determine how services marketing can be applied to prevent and control criminal behavior among undergraduates, the research design employed for this study is the "survey" research method. Based on this, the systematic method of gathering data through the use of structured questionnaire and interview with a reasonably large number and a highly representative sample of undergraduates was adopted. Data collected and collated were structured and analyzed based on the use of Tables and Descriptive statistics.

\subsection{Area of Study}

In practice, the result of this study is applicable to all youths in all tertiary institutions in Nigeria. But because of the nature of the topic, the study was executed using Universities in south-eastern states of Nigeria. Table 7 below shows a breakdown of universities in each state of the south-eastern part of Nigeria.

\begin{tabular}{|c|c|c|c|}
\hline S/No & State & Universities & Year Established \\
\hline 1 a. & Abia & (a) Abia State University, Uturu (ABSU) & 1981 \\
& & (b) Federal University of Agriculture, Umudike & 2002 \\
& & (c) Gregorian University, Uturu & 2010 \\
\hline 2. & Anambra & Nnamdi Azikwe University, Awka & 1992 \\
& & Anambra State University, Uli & 1999 \\
& & Madonna University, Okija Campus & 2000 \\
& & Tansian University, Umunya. & 2010 \\
& & Pauls University, Awka & 2010 \\
\hline 3. & Ebonyi & (a) Ebonyi State University, Abakaliki & 1999 \\
& & (b) Federal University, Abakaliki & 2012 \\
\hline 4 & Enugu & (a) University of Nigeria, Nsukka & 1965 \\
& & (b) Enugu State University of Science and & 1979 \\
& & Technology, Enugu & 2004 \\
& & (c) Caritas University, Enugu & 2012 \\
\hline 5. & IM0 & (a) Federal University of Technology, Owerri & 1983 \\
& & (b) Imo State University, Owerri & 1992 \\
\hline
\end{tabular}

Table 7: Universities in the South- Eastern States of Nigeria

Source: National University Commission (2012)

In view of the fact that criminality among undergraduates is more prevalent in government owned Universities (Adebayo: 2006), the researcher used his personal judgment to choose the oldest government owned university in each state. The selected universities are as shown in Table 8 below.

\begin{tabular}{|c|c|c|c|}
\hline S/No & State & Universities & Year \\
\hline 1a. & Abia & (a) Abia State University, Uturu & 1981 \\
\hline 2. & Anambra & Nnamdi Azikwe University, Awka & 1992 \\
\hline 3. & Ebonyi & (a) Ebonyi State University Abakaliki & 1999 \\
\hline 4 & Enugu & (a) University of Nigeria Nsukka & 1965 \\
5 & Imo & (a) Federal University of Technology, Owerri & 1981 \\
\hline
\end{tabular}

Table 8: Selected Universities from the South- Eastern States of Nigeria.

Source: National University Commission (2012)

\subsection{Source of Data}

The data for this study were obtained from two major sources: the secondary sources and the primary sources. 


\subsubsection{Secondary Data}

For this study, secondary data were generated from relevant existing literature obtained from diverse sources. These sources include: Textbooks, Journals, Newspapers, Magazines, Criminal records from the Nigeria Police Force and the Internet.

\subsubsection{Primary Data}

For this study, primary data were obtained from a sample of students and the Chief Security Officers of the selected universities through the use of questionnaire and interview.

\subsubsection{Research Instrument}

The research instruments used for gathering primary data for this study are the Questionnaire and Interview.

\subsubsection{Questionnaire}

One set of Questionnaire but divided into two parts was administered to the undergraduates in the selected universities. The Questionnaire as shown in appendix A is structured in the 5-point scale of Strongly agree (5), Agree (4), Disagree (3), Strongly Disagree (2) and Undecided (1), in section A and also, some other open-ended questions aimed at eliciting respondent's demographic variables in section B.

\subsubsection{Interview}

Principally, interview was conducted with the Chief Security Officers of the Universities selected. List of Interview questions is attached as appendix B'. The main reason for the interview was to clarify some salient issues that cannot be adequately provided by the undergraduates of the universities. Also, interview was conducted with some students who had difficulty in filling the questionnaire but eager to supply information because of the interest they have for the topic. It is worthy to note that all the questions in the questionnaire and interview schedule are based on the stated research problems, research objectives, research questions and hypotheses.

\subsection{Population of the Study}

Because of the difficulty in accessing the entire undergraduates in all the universities selected, the researcher employed the multi-stage cluster sampling method to ascertain the number of students in each of the universities selected from each state (cluster). Thus, the population of students in the selected universities in each state is shown in Table 9 below.

\begin{tabular}{|c|c|c|c|}
\hline S/No & State & Universities & Student's Population \\
\hline 1a. & Abia & (a) Abia State University, Uturu & 23,400 \\
\hline 2. & Anambra & Nnamdi Azikwe University, Awka & 24,706 \\
\hline 3. & Ebonyi & (a) Ebonyi State University Abakaliki & 12,800 \\
\hline 4 & Enugu & (a) University of Nigeria Nsukka & 35,740 \\
\hline 5. & IMO & (a) Federal University of Technology, Owerri & 22,581 \\
\hline & Total & 119,227 \\
\hline
\end{tabular}

Table 9: Population of Students in the Selected Universities

Source: National University Commission (2012)

Based on the figures above, the population for this study is 119227.

\subsection{Sample Size Determination}

Sample size is the definite number of respondents selected from the target population for the study (119227). Their responses represent that of the target population. To realize the objectives of this study, the researcher traded with caution in determining and choosing the sample size. This is in line with the recommendations by Ezejelue, Ogwo and Nkamnebe (2008) and Baridam (1995). The caution took the form of minimizing sampling errors in order to maximize representativeness. Also, a 95 percent (0.05) confidence level is used so as to achieve a more reliable representation by the respondents.

Based on the above, sample size for this study is determined as follows:

- Using Yaro Yemen's formula to determine the overall sample size for the study using the study population which is 119227 .

- Step 1

- Determine the sample size for each university in the ratio of their students' population.

The formula

$\mathrm{n}=$

Where $n$

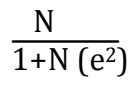

$=\quad$ Sample Size

$\mathrm{N}=$ Population Size

$\mathrm{E}=\quad$ the level of significance $\mathrm{r}$ precision desired

I $=$ Constant 
is 0.05 .

Please note that the confidence level for this study is 95\%, therefore, the level of significance or precision desired

Therefore the value of $(n)$ is:

Approximately $=400$

$\frac{119227}{1+119227(0.05)^{2}}=398.6$

This means that 400 copies of the questionnaire will be distributed to the selected universities in the five states.

- $\quad$ Step 2

Determine the sample size for each university in the selected states in the ratio of their student's population.

(1) Abia State University, Uturu

$$
\frac{23400}{119227} \times 400 \quad=78.505 \quad \ldots \quad 79
$$

(2) Nnamdi Azikiwe University, Awka

$\frac{24706}{119227} \times 400 \quad=82.88 \ldots 3$

(3) Ebonyi State University, Abakaliki

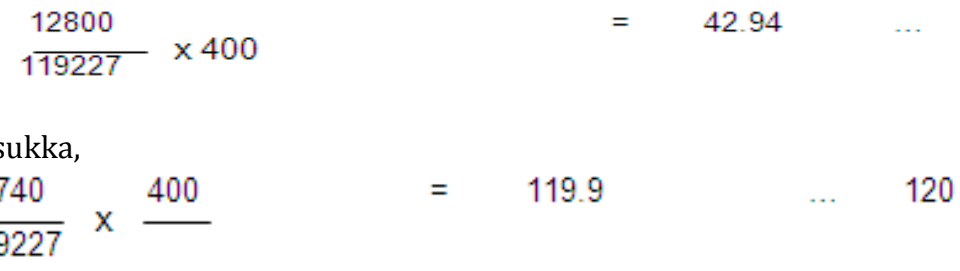

(5) Federal University of Technology, Owerri

$\frac{22581}{119227} \times \frac{400}{1} \quad=75.45 \quad \cdots \frac{75}{400}$

\subsubsection{Sampling Technique}

For this study, the convenience non-probability sampling method was used to distribute copies of the questionnaire to the students in the tertiary institutions selected. The researcher personally entered the classrooms to administer the questionnaires after taking permission from lecturers who were lecturing in such classes.

\subsubsection{Validity Test}

For this study, the preparation of the questionnaire was done with extreme care to ensure that the content and construct validity are realized. To realize the content validity, the questionnaire was validated by selected academics and other persons who are specialist in the field of research as well as the supervisors of this work. For the construct validity, the factor analysis method was used. The test is shown as factor loading in table 10 . For this study, factor loading of 0.50 and above were adopted because they are practically significant. The SPSS output test conducted for this study shows that all the factors are acceptable.

\subsubsection{Reliability Test}

For this study, a survey method and the Cronbach Alpha Statistical method were employed for the test of reliability. For the survey method, twenty-five copies of the Questionnaire were distributed to the final year students of Law department in the five Universities chosen (that is five students in each University). Based on this, final year Law students were not used in the main test. Thereafter, the Cronbach's' Alpha Reliability test was applied. The Cronbach's Alpha is a co-efficient of reliability used to determine internal consistency or average correlation of items in a survey instrument to gauge its ratability (Nunnaly: 1978). For this study, the reliability test conducted with the Cronbach's' Alpha test is shown in table 10 below. 


\begin{tabular}{|c|c|c|c|c|}
\hline S/N & Variables & Factor Loading & No of Items & Cronchas' Alpha \\
\hline 1 & Quality of Education services & 0.973 & 5 & 0.750 \\
\hline 2 & Attitude of staff & 0.835 & 5 & 0.776 \\
\hline 3 & Social marketing activities & 0.680 & 7 & 0.631 \\
\hline 4 & Use of advertising massages & 0.789 & 5 & 0.824 \\
\hline 5 & Public relations activities & 0.785 & 9 & 0.731 \\
\hline 6 & Publicity activities & 0.855 & 5 & 0.770 \\
\hline
\end{tabular}

Table 10: Reliability Test of Various Variables

Overall Cronbach Value $=0.921$. a Copy of the Reliability Test Is Attached as Appendix B

Source: SPSS Output Version 22, (2014)

\subsubsection{Data Analyses}

Collected data are represented in tables for easy understanding and analyzed using Descriptive Statistics: mean and standard deviation through SPSS version 22.

\subsubsection{Hypotheses Testing}

Multiple linear regression (MLR) was employed in analyzing all the research hypotheses formulated for the study. This was also achieved through the use of SPSS version 22.A copy of the Regression analyses is attached as APPENDIX C.

\subsubsection{Decision Rule}

In deciding to reject or accept any tested hypotheses, the values of P (Significant values) and the F-ratio were used. Thus, if the P-value produced by the SPSS output is less than alpha (0.05), and the F-value calculated (SPSS output) is greater than the F-critical values (from the tables) at the appropriate degree of freedom, the null hypothesis is rejected and the alternative accepted, and vice versa. This is also applicable to all the independent variables used in testing the hypothesis.

\section{Data Analysis and Interpretation}

\subsection{Preamble}

This chapter contains procedures for analyzing and testing the primary data obtained for this study. It is subdivided into: data presentation, descriptive statistics for analysis of the research questions, hypotheses testing and discussion of findings.

\subsection{Data Presentation}

This section houses the distribution of questionnaire as well as the tabulation of data derived from the responses of respondents. These are shown in tables 4.1, 13 and 15.

\begin{tabular}{|c|c|c|c|c|}
\hline Universities & Number Distributed & $\begin{array}{c}\text { Number Properly Filled } \\
\text { And Returned }\end{array}$ & $\begin{array}{c}\text { Number Not Properly } \\
\text { Filled But Returned }\end{array}$ & $\begin{array}{c}\text { Number Not } \\
\text { Returned }\end{array}$ \\
\hline ABSU & 79 & $75(94.93 \%)$ & & $4(5.07 \%)$ \\
\hline EBSU & 43 & $39(90.69 \%)$ & & $4(9.31 \%)$ \\
\hline UNN & 120 & $110(91.69 \%)$ & $7(5.83 \%)$ & $3(2.5 \%)$ \\
\hline UNIZIK & 83 & $80(96.38 \%)$ & $3(3.61 \%)$ & \\
\hline FUTO & 75 & $69(90.78 \%)$ & & $10(13.16 \%)$ \\
\hline TOTAL & 400 & $373(93.25 \%)$ & 10 & 21 \\
\hline
\end{tabular}

Table 11: Questionnaire Distribution

Source: Field Survey 2015

From table 11 above, 79 copies of questionnaire were distributed in Abia State University, Uturu (ABSU). Out of this,75(94.93\%) were properly filled and returned, while $4(5.07 \%)$ were not returned. 43 copies of questionnaire were distributed in Ebonyi State University, Abakaliki (EBSU), out of which 39 (90.69\%) were properly filled and returned while $4(9.31 \%)$ were not returned. 120 copies of questionnaire were distributed in University of Nigeria Nsukka (UNN), out of which 110 (91.69\%) were properly filled and returned, 7(5.83\%) were not properly filled but returned while 3(2.5\%) were not returned. 83 copies of questionnaire were distributed in Nnamdi Azikiwe University (UNIZIK). Out of this, $80(96.38 \%)$ were properly filled and returned, while $3(3.61 \%)$ were not returned. 75 copies of questionnaire were distributed in Federal University of Technology Owerri (FUTO). Out of this, 69(90.78\%) were properly filled and returned, while $10(13.16 \%)$ were not returned. This distribution is summarized in table 12 below.

\begin{tabular}{|c|c|c|c|}
\hline Number Distributed & $\begin{array}{c}\text { Number Properly Filled } \\
\text { and Returned }\end{array}$ & $\begin{array}{c}\text { Number Not Properly } \\
\text { Filled but Returned }\end{array}$ & Number Not Returned \\
\hline 400 & $373(93.25 \%)$ & 10 & 21 \\
\hline
\end{tabular}

Table 12: Summary of Questionnaire Distribution

Source: Field survey 2015 
From table 12 above, out of 400 copies of questionnaire distributed to the respondents, 373 copies were returned as duly filled and usable, thus giving a response rate of $93.25 \%$. This is quite high for a study of this nature and was informed by the method of distribution adopted by the researcher with the aid of assistants who were trained for the purpose. Thus, the analysis for this study is based on the responses of 373 respondents.

\subsection{Data Analysis}

Data obtained from 373 respondents for this study are hereby analyzed using the descriptive statistics (mean and standard deviations to show convergence and divergence of respondent opinions). The analyses are as follows:

\subsubsection{Research Question One}

Services marketing tools for crime prevention and control among undergraduates.

These tools also represent the determinants of Undergraduates' criminal behavior (UCB) and the Dependent Variables.

\subsubsection{Scales/ Rating/Frequency}

\begin{tabular}{|c|c|c|c|c|c|c|}
\hline S/NO & & $\begin{array}{c}\text { A } \\
\text { (5) }\end{array}$ & $\begin{array}{c}\text { SA } \\
\text { (4) }\end{array}$ & $\begin{array}{c}\text { DA } \\
\text { (3) }\end{array}$ & $\begin{array}{c}\text { SD } \\
\text { (2) }\end{array}$ & $\begin{array}{c}\text { UD } \\
\text { (1) }\end{array}$ \\
\hline Question 1 & SMTs FOR (UCB) & & & & & \\
\hline & (a) QES & 197 & 120 & 42 & 8 & 6 \\
\hline & & 147 & 171 & 39 & 11 & 5 \\
\hline & & & & & & \\
\hline & (b) ASP & 209 & 127 & 19 & 9 & 9 \\
\hline & (c) SMN & 189 & 121 & 33 & 14 & 16 \\
\hline & (e) PRA & 211 & 130 & 26 & 5 & 1 \\
\hline & (F) PBA & 200 & 97 & 53 & 15 & 8 \\
\hline
\end{tabular}

Table 13: Tabulated Responses of Respondents on Services Marketing Tools for

Crime Prevention and Control among Undergraduates

Source: Primary data by the Researcher

Please note that:

- $\quad$ SMTs $=$ Services marketing tools

- $\mathrm{UCB}=$ Undergraduate Criminal Behavior

- $\quad$ QES = Quality Education Services

- $\quad \mathrm{ASP}=$ Attitude of staff/Personnel of tertiary institution

- $\quad \mathrm{SMA}=$ Social media activities

- $\quad \mathrm{ADM}=$ Advertising media activities.

- $\quad$ PRA = Public relations activities

- $\quad \mathrm{PBA}=$ Publicity activities

A means agree

- SA means strongly agree

- DA means disagree

- SD means strongly disagree

- UD means undecided

\begin{tabular}{|c|c|c|c|c|c|}
\hline & $\mathbf{N}$ & Minimum & Maximum & Mean & Std. Deviation \\
\hline undergraduates criminal behavior 1 & 373 & 1 & 6 & 4.28 & .947 \\
\hline undergraduates criminal behavior 2 & 373 & 1 & 6 & 4.24 & .939 \\
\hline undergraduates criminal behavior 3 & 373 & 1 & 6 & 3.82 & 1.151 \\
\hline undergraduates criminal behavior 4 & 373 & 1 & 6 & 3.97 & 1.039 \\
\hline undergraduates criminal behavior 5 & 373 & 1 & 6 & 3.94 & 1.211 \\
\hline undergraduates criminal behavior 6 & 373 & 1 & 6 & 3.92 & 1.200 \\
\hline Valid N (list wise) & 373 & & & & \\
\hline
\end{tabular}

Table 14: Undergraduate Criminal Behavior Descriptive Statistics

Source: Field Survey 2015 Using SPSs Version 22 (2014)

From Table 13, six items were used to measure crime behavior among undergraduates in tertiary institutions; and from the responses, the students are in disagreement over crime behavior. Though the mean responses are closer to the 
maximum, the standard deviations of four items are more than one, while that of the remaining two variables are less than one. In the model used for this study, these are the dependent variables.

\subsubsection{Research Question 2}

Nature of Quality of education services by the universities that can prevent and control crime among undergraduates.

\begin{tabular}{|c|c|c|c|c|c|c|}
\hline S/NO & & A & SA & DA & SD & UD \\
& & (5) & (4) & (1) & \\
\hline Question 2 & QES & & & & & 11 \\
\hline & Reliability & 210 & 116 & 22 & 20 & 11 \\
\hline & Tangibles & 156 & 139 & 47 & 34 & 7 \\
\hline & Responsiveness & 203 & 117 & 12 & 18 & 10 \\
\hline & Assurance & 150 & 154 & 41 & 22 & 8 \\
\hline & Empathy & 164 & 125 & 54 & 16.6 & 10 \\
\hline
\end{tabular}

Table 15: Tabulated Responses on Nature of Quality of Education Services (QES) by the

Universities That Can Prevent and Control Crime among Undergraduates

Source: Primary Data by the Researcher 2015

\begin{tabular}{|c|c|c|c|c|c|}
\hline & N & Minimum & Maximum & Mean & Std. Deviation \\
\hline service quality by the institutions 1 & 373 & 1 & 5 & 4.37 & .935 \\
\hline service quality by institutions 2 & 373 & 1 & 5 & 4.37 & .838 \\
\hline service quality by institutions 3 & 373 & 1 & 5 & 4.26 & .895 \\
\hline service quality by institutions 4 & 373 & 1 & 5 & 4.18 & .930 \\
\hline service quality by institutions 5 & 373 & 1 & 5 & 4.35 & .923 \\
\hline Valid N & 373 & & & & \\
\hline
\end{tabular}

Table 16: Descriptive Statistics on Quality of Education Services

Source: Response to Research Question 2 Using SPSS Version 2015

From Table 15, five variables were used to measure and ascertain the opinions of students with respect to quality of education services. The items show very high mean with very low standard deviation and this means that most of the students strongly agree that quality of education services can curb criminality among students. The mean responses are much closer to the maximum than the minimum; and all the standard deviations are less than one, which confirms strong agreement.

\subsubsection{Research Question 3}

Attitude of staff/personnel (ASP) of tertiary institutions that contribute to the prevention and control of crime amongst youths in tertiary institutions.

\begin{tabular}{|c|c|c|c|c|c|c|}
\hline S/NO & & $\begin{array}{c}\text { A } \\
(5)\end{array}$ & $\begin{array}{l}\text { SA } \\
(4)\end{array}$ & $\begin{array}{l}\text { DA } \\
(3)\end{array}$ & $\begin{array}{l}\text { SD } \\
(2)\end{array}$ & $\begin{array}{l}\text { UD } \\
\text { (1) }\end{array}$ \\
\hline \multicolumn{7}{|l|}{ Question 3} \\
\hline & Regular attendance to classes & 159 & 155 & 38 & 15 & 6 \\
\hline & $\begin{array}{l}\text { Using teaching methods that } \\
\text { keep undergraduates busy. }\end{array}$ & 172 & 145 & 35 & 12 & 9 \\
\hline & $\begin{array}{l}\text { Give undergraduates free access } \\
\text { to their results }\end{array}$ & 129 & 145 & 59 & 25 & 15 \\
\hline & $\begin{array}{c}\text { Always wearing a mood before } \\
\text { undergraduates }\end{array}$ & 152 & 141 & 45 & 18 & 16 \\
\hline & $\begin{array}{l}\text { Act as change agents to } \\
\text { undergraduates through } \\
\text { counseling. }\end{array}$ & 187 & 116 & 33 & 28 & 9 \\
\hline Mean Score & & 159.8 & 140.4 & 42 & 19.8 & 11 \\
\hline
\end{tabular}

Table 17: Response to the Attitude of Staff (Personnel of Tertiary Institutions That

Contribute to the Prevention and Control of Crime amongst Youths in Tertiary Institutions

Source: Primary Data by the Researcher 2015 


\begin{tabular}{|c|c|c|c|c|c|}
\hline & N & Minimum & Maximum & Mean & Std. Deviation \\
\hline attitude of staff 1 & 373 & 1 & 5 & 4.40 & .845 \\
\hline attitude of staff 2 & 373 & 1 & 5 & 3.92 & 1.114 \\
\hline attitude of staff 3 & 373 & 1 & 5 & 4.43 & .838 \\
\hline attitude of staff 4 & 373 & 1 & 5 & 4.21 & .927 \\
\hline attitude of staff 5 & 373 & 1 & 5 & 4.38 & .861 \\
\hline Valid N (listwise) & 373 & & & & \\
\hline
\end{tabular}

Table 18: Attitude of Staff Descriptive Statistics

Source: Response to Research Question 3

Table 17 above shows that five variables were used as indices to measure the opinions of students with respect to attitude of staff (personnel). Item 2 (using teaching method that keeps undergraduates busy) has the lowest mean with standard deviation more than one. This is still closer to the maximum than the minimum. The other four items show very high mean which is closer to the maximum with very low standard deviation. This means that most of the undergraduates strongly agreed that attitude of staff (personnel) of tertiary institutions contribute to the prevention and control of crime amongst youths of tertiary institutions. This is because; students contact with staff is higher than with any other person or group of persons. The implication of this is that the attitude of staff (personnel) contributes to a large extent in crime prevention and control among undergraduates.

\subsubsection{Research Question 4}

The extent to which the use of social media network (SMN) contributes to crime prevention and control among youths in tertiary institutions.

\begin{tabular}{|c|c|c|c|c|c|c|}
\hline S/No & & A & Sa & Da & Sd & Ud \\
$(2)$ & $(4)$ & & & \\
& & & & & & \\
\hline Question 4 & SMN & & & & & \\
& Facebook & 157 & 115 & 62 & 31 & 8 \\
\hline & Skype-Twitter & 135 & 120 & 69 & 37 & 17 \\
\hline & Whatsapp & 144 & 143 & 75 & 6 & 5 \\
\hline & 2-Go/Eskimo & 127 & 113 & 69 & 40 & 24 \\
\hline & MNS & 117 & 115 & 94 & 25 & 22 \\
\hline Mean Score & Foursquare & 159.8 & 117.2 & 68 & 30.8 & 15.3 \\
\hline
\end{tabular}

Table 19: Response to the Extent to Which the Use of Social Media Network Contribute to Crime Prevention and Control among Youths in Tertiary Institutions. Source: Primary Data by the Researcher 2015

\begin{tabular}{|c|c|c|c|c|c|}
\hline & N & Minimum & Maximum & Mean & Std. Deviation \\
\hline Facebook & 373 & 1 & 5 & 4.27 & 1.079 \\
\hline skype-twitter & 373 & 1 & 5 & 3.79 & 1.109 \\
\hline WhatsApp & 373 & 1 & 5 & 3.43 & 1.250 \\
\hline Eskimo & 373 & 1 & 5 & 3.35 & 1.303 \\
\hline Mns & 373 & 1 & 5 & 3.25 & 1.355 \\
\hline Foursquare & 373 & 1 & 5 & 3.23 & 1.409 \\
\hline Valid N (listwise) & 373 & & & & \\
\hline
\end{tabular}

Table 20: Social Media Activities Descriptive Statistics

Source: Response to Research Question 4

Social media are agents of communication and socialization hence undergraduates spend reasonable number of hours on them daily. From the responses in Table 19 above, the opinions are diverse as all the standard deviations above are indicating varied opinion. Though the means are closer to the maximum, the deviations are very high which is an indication that social media networks can be bad and also good.

\subsubsection{Research Question 5}

The extent to which the use of selected advertising media such as billboards, newspapers, radio, and television by tertiary institutions can achieve crime prevention and control among youths in tertiary institutions. 


\begin{tabular}{|c|c|c|c|c|c|c|}
\hline S/NO & & A (5) & SA (4) & DA (3) & SDA (2) & UD (1) \\
\hline Question 5 & ADM & & & & & \\
\hline & Billboards & 170 & 114 & 34 & 38 & 17 \\
\hline & Newspapers/Magazines & 146 & 136 & 60 & 28 & 3 \\
\hline & $\begin{array}{c}\text { Radio } \\
\text { Television }\end{array}$ & $\begin{array}{l}137 \\
148\end{array}$ & $\begin{array}{l}135 \\
130\end{array}$ & $\begin{array}{l}75 \\
59\end{array}$ & $\begin{array}{l}16 \\
26\end{array}$ & $\begin{array}{l}10 \\
10\end{array}$ \\
\hline & & 148 & 130.25 & 59 & 26 & 10.25 \\
\hline Mean Score & & & & & & \\
\hline
\end{tabular}

Table 21: Response to the Extent to Which the Use of Selected Advertising Media Such As Billboards, Newspapers, Radio, and Television by Tertiary Institutions Can Achieve Crime Prevention and Control among Youths in Tertiary Institutions Source: Primary Data by the Researcher 2015

\begin{tabular}{|c|c|c|c|c|c|}
\hline & $\mathbf{N}$ & Minimum & Maximum & Mean & Std. Deviation \\
\hline Billboards & 373 & 1 & 5 & 4.28 & 1.058 \\
\hline newspapers/magazines & 373 & 1 & 5 & 4.37 & .814 \\
\hline Radio & 373 & 1 & 5 & 4.34 & .812 \\
\hline Television & 373 & 1 & 5 & 4.48 & .841 \\
\hline Valid N (listwise) & 373 & & & & \\
\hline
\end{tabular}

Table 22: Advertising Media Descriptive Statistics

Source: Response to Research Question 5

Like social media, advertising media are channels of communications. The information in Table 21 above show that the four advertising media used in the study attract very high mean response rate much closer to the maximum than the minimum responses. Only billboards have standard deviations above one, while others are below one indicating agreement with the propositions. This also means that billboards do not attract as much attention as other media.

\subsubsection{Research Question 6}

The extent to which the use of public relations activities by tertiary institutions can achieve the objective of crime prevention and control among undergraduates in tertiary institutions.

\begin{tabular}{|c|c|c|c|c|c|c|}
\hline S/No & & $\begin{array}{c}\text { A } \\
\text { (5) }\end{array}$ & $\begin{array}{c}\text { Sa } \\
(4)\end{array}$ & $\begin{array}{l}\text { Da } \\
\text { (3) }\end{array}$ & $\begin{array}{l}\text { Sd } \\
(2)\end{array}$ & $\begin{array}{l}\text { Ud } \\
\text { (1) }\end{array}$ \\
\hline \multirow{10}{*}{ Question 6} & Public Relations Activities & & & & & \\
\hline & Donation Of Free Buses For Transportation & 178 & 102 & 66 & 17 & 10 \\
\hline & Sponsoring Sporting Activities & 160 & 110 & 87 & 11 & 5 \\
\hline & Sponsoring Academic Activities & 219 & 114 & 31 & 7 & 2 \\
\hline & Donations To Sug & 146 & 120 & 64 & 25 & 18 \\
\hline & Sponsoring Social Activities & 135 & 115 & 84 & 29 & 10 \\
\hline & Sponsoring Trade Fairs & 193 & 127 & 31 & 15 & 7 \\
\hline & Donation Of Cafeteria And Bar & 180 & 104 & 69 & 11 & 8 \\
\hline & Donation Of Sporting Facilities & 194 & 144 & 21 & 6 & 8 \\
\hline & Use Of Internal Magazines & 165 & 86 & 92 & 20 & 10 \\
\hline Mean Score & & 174.4 & 113.6 & 60.6 & 15.7 & 10.3 \\
\hline
\end{tabular}

Table 23: Response to the Extent to Which the Use of Public Relations Activities by Tertiary Institutions Can Achieve the Objective of Crime Prevention and Control among Youth in Tertiary Institutions Source: Primary Data by the Researcher 2015

\begin{tabular}{|c|c|c|c|c|c|}
\hline & N & Minimum & Maximum & Mean & Std. Deviation \\
\hline pr activities 1 & 373 & 1 & 5 & 4.47 & .720 \\
\hline pr activities 2 & 373 & 1 & 5 & 4.06 & .983 \\
\hline Pr activities 3 & 373 & 1 & 5 & 4.46 & .830 \\
\hline Pr activities 4 & 373 & 1 & 5 & 3.85 & 1.088 \\
\hline pr activities 5 & 373 & 1 & 5 & 3.76 & 1.096 \\
\hline pr activities 6 & 373 & 1 & 5 & 4.16 & .013 \\
\hline pr activities 7 & 373 & 1 & 5.37 & .812 \\
\hline pr activities 8 & 373 & 1 & 5 & 4.12 & .930 \\
\hline pr activities 9 & 373 & 1 & 5 & 3.99 & 1.116 \\
\hline Valid N & 373 & & & & \\
\hline
\end{tabular}

Table 24: Public Relations Descriptive Statistics

Source: Response to Research Question 6 
Public relations activities are tools built into strategies for image making, reputation management and maintenance of cordiality among the various publics of an organization. Nine items were used to measure the Public relations activities and they show varied responses. As shown in Table 23 above, items 1,2,3,6,7,and 8 have mean responses above four (4) with standard deviation less than one showing agreement while the remaining items have mean responses below four. Four of the five items have standard deviation more than one, which shows disagreement with the propositions.

\subsubsection{Research Question 7}

The extent to which the use of publicity activities by tertiary institutions can achieve the objective of crime prevention and control among youth in tertiary institutions.

\begin{tabular}{|c|c|c|c|c|c|c|}
\hline S/NO & & $\begin{array}{c}\text { A } \\
\text { (5) }\end{array}$ & $\begin{array}{c}\text { SA } \\
(4)\end{array}$ & $\begin{array}{c}\text { DA } \\
(3)\end{array}$ & $\begin{array}{c}\text { SD } \\
(\mathbf{2})\end{array}$ & $\begin{array}{c}\text { UD } \\
(\mathbf{1})\end{array}$ \\
\hline Question 7 & Publicity activities (PBA) & & & & & \\
\hline & News release & 174 & 138 & 47 & 6 & 8 \\
\hline & Press conference & 235 & 102 & 18 & 14 & 4 \\
\hline & Feature articles & 144 & 137 & 78 & 11 & 3 \\
\hline & Photographs & 144 & 132 & 67 & 17 & 13 \\
\hline & Films and Videotapes & 148 & 137 & 70 & 13 & 5 \\
\hline Mean Score & & 143 & 130.4 & 56 & 12.2 & 6.6 \\
\hline
\end{tabular}

Table 25: Response to the Extent to Which the Use of Publicity Activities by Tertiary Institutions Can Achieve the Objective of Crime Prevention and Control among Youth in Tertiary Institutions Source: Primary Data by the Researcher 2015

\begin{tabular}{|c|c|c|c|c|c|}
\hline & N & Minimum & Maximum & Mean & Std. Deviation \\
\hline publicity activities 1 & 373 & 1 & 5 & 4.40 & .845 \\
\hline publicity activities 2 & 373 & 1 & 5 & 3.92 & 1.115 \\
\hline publicity activities 3 & 373 & 1 & 5 & 4.47 & .830 \\
& & & & & .927 \\
\hline publicity activities 4 & 373 & 1 & 5 & 4.22 & .882 \\
\hline publicity activities 5 & 373 & 1 & 5 & 4.38 & \\
\hline Valid N (iistwise) & 373 & & & & \\
\hline
\end{tabular}

Table 26: Publicity Activities Descriptive Statistics Source: Response to Research Question 6

Also, publicity activities are tools and strategies for image making, and reputation management with target publics of an organization. Table 4.8 above shows that five variables were used as indices to measure the opinions of undergraduates with respect to impact of publicity activities on undergraduate criminal behavior. Item 2 has the lowest mean with standard deviation more than one. This is still closer to the maximum than the minimum. The other four items show very high mean which is closer to the maximum with very low standard deviation. This means that most of the students strongly agree that publicity activities by tertiary institutions contribute to the prevention and control of crime amongst youths of tertiary institutions.

\subsubsection{Research Question 8, 9,10: Demographic Characteristics of Respondents}

This section of the questionnaire is used to prove the nature and ability of the respondents towards providing reliable data for the study. Data presented in table 27 are utilized for this analysis. These are represented under sex, age bracket and level of students in the University. 


\begin{tabular}{|c|c|c|c|}
\hline \multicolumn{4}{|c|}{ Sex } \\
\hline S/NO & Sex & Frequency & Percentage \\
\hline (a) & Male & 173 & 46.4 \\
\hline (b) & Female & 200 & 53.6 \\
\hline Total & & 373 & 100 \\
\hline \multicolumn{4}{|c|}{ Age } \\
\hline S/NO & Sex & Frequency & Percentage \\
\hline (a) & $17-20$ & 90 & 24.1 \\
\hline (b) & $21-25$ & 265 & 71 \\
\hline (c) & $26-30$ & 16 & 4.3 \\
\hline (d) & 31 and above & 2 & 0.5 \\
\hline Total & & 373 & 100 \\
\hline \multicolumn{4}{|c|}{ Level of Students in the University } \\
\hline $\mathrm{S} / \mathrm{NO}$ & LEVEL & FREQUENCY & PERCENTAGE \\
\hline (a) & 100 & 18 & 4.8 \\
\hline (b) & 200 & 139 & 37.3 \\
\hline (C) & 300 & 124 & 38.2 \\
\hline (d) & 400 & 68 & 18.2 \\
\hline (e) & 500 & 13 & 3.5 \\
\hline (f) & PG & 11 & 2.9 \\
\hline Total & & 373 & 100 \\
\hline
\end{tabular}

Table 27: Response to the Demographic Characteristics of Respondents Source: Primary Data by the Researcher 2015

\begin{tabular}{|c|c|c|c|c|c|}
\hline & & Frequency & Percent & Valid Percent & Cumulative Percent \\
\hline \multirow[t]{3}{*}{ Sex: } & Male & 173 & 46.4 & 46.4 & 46.4 \\
\hline & Female & 200 & 53.6 & 53.6 & 100.0 \\
\hline & Total & 373 & 100.0 & 100.0 & \\
\hline \multirow[t]{5}{*}{ Age bracket: } & 17-20 years & 90 & 24.1 & 24.1 & 24.1 \\
\hline & 21-25 years & 265 & 71.0 & 71.0 & 95.2 \\
\hline & $26-30$ years & 16 & 4.3 & 4.3 & 99.5 \\
\hline & 31 and above & 2 & .5 & .5 & 100.0 \\
\hline & Total & 373 & 100.0 & 100.0 & \\
\hline \multirow{7}{*}{$\begin{array}{l}\text { Level of } \\
\text { students: }\end{array}$} & 100 level & 18 & 4.8 & 4.8 & 4.8 \\
\hline & 200 level & 139 & 37.3 & 37.3 & 42.1 \\
\hline & 300 level & 124 & 33.2 & 33.2 & 75.3 \\
\hline & 400 level & 68 & 18.2 & 18.2 & 93.6 \\
\hline & 500 level & 13 & 3.5 & 3.5 & 97.1 \\
\hline & postgraduate & 11 & 2.9 & 2.9 & 100.0 \\
\hline & Total & 373 & 100.0 & 100.0 & \\
\hline
\end{tabular}

Table 28: Demographic Characteristics of Respondents

Source: Response to Research Questions 8, 9, and 10

Table 4.9 .1 above shows $53.6 \%$ (200) of the respondents are females while $46.4 \%$ (173) are males. On age bracket, $24.1 \%$ (90) respondents are within 17 - 20 years age bracket; $71.0 \%$ (265) of the student respondents are within 21-25 years; $4.3 \%$ (16) are within 26- 30 years age bracket while the remaining $0.5 \%$ (2) fall within 30 years and above. The majority of the respondents fall within the 21-25 years age bracket and the implication of this is that this age bracket is the youth and is vibrant and is in active schooling age. On the number of years the respondents have spent on campus, 4.8\% (18) are in 100 levels; 37.3\% (139) are in 200 levels; 33.2\% (124) are in 300 levels; 18.2\% (68) are in 400 level; $3.5 \%$ (13) are in 500 levels while the remaining 2.9\% (11) are postgraduate students. From this, it is clear that majority of the respondents have spent two years or more on campus and the implication of this is that they are in a better position to appreciate the import of the study and the variables/factors under study.

\subsection{Test of Hypotheses}

Six hypotheses were formulated for the study and are stated in null form. The data presented on Tables $4.2,4.3,4.4,19,21,23$ and 4.8 were used accordingly for each of the variables to test the hypotheses using Multiple Regression Analysis. The hypotheses were tested individually using the ordinary least squares (OLS) regression method. The analysis was carried out with the aid of statistical package for social sciences (SPSS) version 22. 


\subsubsection{Test of Hypothesis One}

- $\mathrm{HO}_{1}$ There is no significant relationship between the Quality of Education Services offered by universities and the prevention and control of crime among undergraduates.

- $\mathrm{HA}_{1}$ There is significant relationship between the Quality of Education Services offered by universities and the prevention and control of crime among undergraduates.

To test this hypothesis, data presented in tables 13 and 15 were utilized. The SPSS output is as shown below:

\begin{tabular}{|c|c|c|c|c|c|}
\hline \multicolumn{5}{|c|}{ Model Summary $^{\mathbf{b}}$} \\
\hline Model & R & R Square & $\begin{array}{c}\text { Adjusted R } \\
\text { Square }\end{array}$ & $\begin{array}{c}\text { Std. Error of } \\
\text { the Estimate }\end{array}$ & Durbin-Watson \\
\hline 1 & $.982^{\text {a }}$ & .964 & .964 & .17212 & 1.82 \\
\hline
\end{tabular}

Table 29

a. Predictors: (Constant), Service Quality Empathy, Service Quality Reliability, Service Quality Assurance, Service Quality Responsiveness, Service Quality Tangibles b. Dependent Variable: Services Marketing Tools

\begin{tabular}{|c|c|c|c|c|c|c|}
\hline \multicolumn{7}{|c|}{ ANOVA $^{\mathbf{a}}$} \\
\hline \multirow{3}{*}{1} & Model & Sum of Squares & df & Mean Square & F & Sig. \\
\cline { 2 - 7 } & Regression & 293.894 & 5 & 58.779 & 1984.085 & $.000^{\text {b }}$ \\
\cline { 2 - 7 } & Residual & 10.872 & 367 & .030 & & \\
\cline { 2 - 7 } & Total & 304.767 & 372 & & & \\
\hline
\end{tabular}

a. Dependent Variable: Services Marketing Tools

b. Predictors: (Constant), Service Quality Empathy, Service Quality Reliability, Service Quality Assurance, Service Quality Responsiveness, Service Quality Tangibles

\begin{tabular}{|c|c|c|c|c|c|c|}
\hline \multicolumn{7}{|c|}{ Coefficients $^{\mathbf{a}}$} \\
\hline & \multirow[t]{2}{*}{ Model } & \multicolumn{2}{|c|}{$\begin{array}{l}\text { Unstandardized } \\
\text { Coefficients }\end{array}$} & \multirow{2}{*}{$\begin{array}{c}\text { Standardized } \\
\text { Coefficients }\end{array}$} & \multirow[t]{2}{*}{$\mathrm{T}$} & \multirow[t]{2}{*}{ Sig. } \\
\hline & & B & Std. Error & & & \\
\hline \multirow[t]{6}{*}{1} & (Constant) & .098 & .045 & & 2.196 & .029 \\
\hline & Service Quality Reliability & -.001 & .035 & -.001 & -.035 & .000 \\
\hline & Service Quality Tangibles & -.018 & .055 & -.020 & -.332 & .000 \\
\hline & $\begin{array}{l}\text { Service Quality } \\
\text { Responsiveness }\end{array}$ & .809 & .040 & .811 & $\begin{array}{c}20.02 \\
2 \\
\end{array}$ & .000 \\
\hline & Service Quality Assurance & .089 & .043 & .095 & 2.096 & .037 \\
\hline & Service Quality Empathy & .101 & .043 & .111 & 2.349 & .019 \\
\hline
\end{tabular}

Table 31

a. Dependent Variable: Services Marketing Tools

\subsubsection{Interpretation}

The $\mathrm{R}$ value in the model summary table shows a simple correlation of 0.982 which shows a high degree of positive correlation. The $\mathrm{R}^{2}$ value shows how much of the total variation in the dependent variable (Services marketing tools for crime prevention and control) that can be explained by the independent variable (Quality of education services). The table shows that $96.4 \%$ variation in crime prevention can be explained by the quality of education services. This is very high. With a sig (p-value) of (0.000) which is less than Alpha (0.05), this implies that the overall regression model statistically predicts the outcome variable. (That is, it is a good fit). Also, a look at the coefficients table reveals that all the independent variables are significant predictors of the dependent variable. Again, the DW value (1.82) which is greater than the Durbin Watson lower value from table (1.72) means that there is no first order autocorrelation since the value of DW produced by the SPSS lies between the lower and upper values from the critical table.

\subsubsection{Decision}

Since the overall P-value (0.000) is less than Alpha (0.05), that is $0.000<0.05$, and F cal (198) greater than F critical from tables (2.37) we therefore reject the null hypothesis and accept the alternative hypothesis which implies that there is a significant relationship between the quality of education services offered by tertiary institutions and the prevention and control of crime among undergraduates.

\subsection{Test of Hypothesis Two}

- $\mathrm{HO}_{2}$ There is no significant relationship between the attitude of staff (personnel) in universities and the prevention and control of crime among undergraduates.

- $\mathrm{HA}_{2}$ There is significant relationship between the attitude of staff (personnel) in universities and the prevention and control of crime among undergraduates.

To test this hypothesis, data presented in tables 13 and 17 were utilized. The SPSS output is as shown below: 


\begin{tabular}{|c|c|c|c|c|c|}
\hline \multicolumn{9}{|c|}{ Model Summary } \\
\hline Model & $\mathrm{R}$ & R Square & $\begin{array}{c}\text { Adjusted R } \\
\text { Square }\end{array}$ & $\begin{array}{c}\text { Std. Error of the } \\
\text { Estimate }\end{array}$ & Durbin-Watson \\
\hline 1 & $.972^{\mathrm{a}}$ & .945 & .944 & .21399 & 1.84 \\
\hline
\end{tabular}

Table 32

a. Predictors: (Constant), Change Agents, Free Access To Results, Attendance To Class, Friendly Mood, Teaching Methods

b. Dependent Variable: Services Marketing Tools

\begin{tabular}{|l|l|l|l|l|l|l|}
\hline \multicolumn{2}{|l|}{ ANOVA $^{\mathbf{a}}$} \\
\hline Model & Sum of Squares & $\mathrm{df}$ & Mean Square & $\mathrm{F}$ & Sig. \\
\hline \multirow{3}{*}{1} & Regression & 287.962 & 5 & 57.592 & 1257.754 & $.000^{\mathrm{b}}$ \\
\cline { 2 - 7 } & Residual & 16.805 & 367 & .046 & & \\
\cline { 2 - 7 } & Total & 304.767 & 372 & & & \\
\hline
\end{tabular}

Table 33

a. Dependent Variable: Services Marketing Tools

b. Predictors: (Constant), Change Agents, Free Access to Results, Attendance to Class, Friendly Mood, Teaching Methods

\begin{tabular}{|c|c|c|c|c|c|c|}
\hline \multicolumn{7}{|c|}{ Coefficients $^{a}$} \\
\hline \multicolumn{2}{|r|}{ Model } & \multicolumn{2}{|c|}{ Unstandardized Coefficients } & \multirow{2}{*}{$\begin{array}{c}\begin{array}{c}\text { Standardized } \\
\text { Coefficients }\end{array} \\
\text { Beta } \\
\end{array}$} & \multirow[t]{2}{*}{$\mathrm{t}$} & \multirow[t]{2}{*}{ Sig. } \\
\hline & & $\mathrm{B}$ & Std. Error & & & \\
\hline \multirow[t]{6}{*}{1} & (Constant) & .396 & .059 & & 6.750 & .000 \\
\hline & Attendance to Class & .036 & .060 & .036 & .600 & .025 \\
\hline & Teaching Methods & .534 & .058 & .544 & 9.267 & .000 \\
\hline & Free Access to Results & .034 & .034 & .040 & 1.028 & .305 \\
\hline & Friendly Mood & -.121 & .047 & -.142 & -2.590 & .010 \\
\hline & Change Agents & .442 & .038 & .506 & 11.493 & .000 \\
\hline
\end{tabular}

Table 34: Dependent Variable: Services Marketing Tools

\subsubsection{Interpretation}

The $\mathrm{R}$ value in the model summary table shows a simple correlation of 0.972 which shows a high degree of positive correlation. The $\mathrm{R}^{2}$ value shows how much of the total variation in the dependent variable (Services marketing tools for crime prevention and control) that can be explained by the independent variable (Attitude of personnel). The table shows that $919 \%$ variation in crime prevention can be explained by the attitude of personnel. This is very high. With a sig (p-value) of (0.000) which is less than Alpha (0.05), this implies that the overall regression model statistically predicts the outcome variable. (That is, it is a good fit). Also, a look at the coefficients table reveals that all the independent variables, apart from free access to results are significant predictors of the dependent variable. Again, the DW value (1.82) which is greater than the Durbin Watson lower value from table (1.71) means that there is no first order autocorrelation since the value of DW produced by the SPSS lies between the lower and upper values from the critical table.

\subsubsection{Decision}

Since the overall P-value (0.000) is less than Alpha (0.05), that is $0.000<0.05$, and F cal (125) greater than F critical from tables (2.37) we therefore reject the null hypothesis and accept the alternative hypothesis which implies that there is a significant relationship between the attitude of staff (personnel) in universities and the prevention and control of crime among undergraduates.

\subsection{Test of Hypothesis Three}

- $\mathrm{HO}_{3}$ There is no significant relationship between activities on social media networks by universities and Prevention and control of crime among undergraduates.

- $\mathrm{HA}_{3}$ There is significant relationship between activities on social media networks by universities and Prevention and control of crime among undergraduates.

To test this hypothesis, data presented in tables 13 and 19 were utilized. The SPSS output is as shown below: 


\begin{tabular}{|c|c|c|c|c|c|}
\hline \multicolumn{6}{|c|}{ Model Summaryb } \\
\hline Model & $\mathrm{R}$ & R Square & $\begin{array}{c}\text { Adjusted R } \\
\text { Square }\end{array}$ & $\begin{array}{c}\text { Std. Error of the } \\
\text { Estimate }\end{array}$ & Durbin-Watson \\
\hline 1 & $.952^{\mathrm{a}}$ & .907 & .906 & .27805 & 1.83 \\
\hline
\end{tabular}

Table 35

a. Predictors: (Constant), Foursquare, 2go-Eskimi, Facebook, Skype - Twitter, Whats-App, Mns b. Dependent Variable: Services Marketing Tools

\begin{tabular}{|c|c|c|c|c|c|c|}
\hline \multicolumn{9}{|c|}{ ANOVA $^{\mathbf{a}}$} & \multicolumn{2}{c|}{ Sig. } \\
\hline \multirow{3}{*}{1} & Model & Sum of Squares & Df & Mean Square & F & $.000^{\mathrm{b}}$ \\
\cline { 2 - 7 } & Regression & 276.470 & 6 & 46.078 & 595.990 & \\
\cline { 2 - 7 } & Residual & 28.297 & 366 & .077 & & \\
\hline
\end{tabular}

Table 36

a. Dependent Variable: Services Marketing Tools

b. Predictors: (Constant), Foursquare, 2go-Eskimi, Facebook, Skype - Twitter, Whats-App, Mns

\begin{tabular}{|c|c|c|c|c|c|c|}
\hline \multicolumn{7}{|c|}{ Coefficients $^{\mathbf{a}}$} \\
\hline & \multirow[t]{2}{*}{ Model } & \multicolumn{2}{|c|}{ Unstandardized Coefficients } & \multirow{2}{*}{$\begin{array}{c}\begin{array}{c}\text { Standardized } \\
\text { Coefficients }\end{array} \\
\text { Beta } \\
\end{array}$} & \multirow[t]{2}{*}{$\mathrm{T}$} & \multirow[t]{2}{*}{ Sig. } \\
\hline & & $\mathrm{B}$ & Std. Error & & & \\
\hline \multirow[t]{7}{*}{1} & (Constant) & .005 & .116 & & .041 & .967 \\
\hline & Facebook & .661 & .044 & .616 & 14.973 & .000 \\
\hline & Skype - Twitter & .208 & .049 & .242 & 4.195 & .000 \\
\hline & Whats-app & .072 & .072 & .096 & 1.012 & .312 \\
\hline & 2go-Eskimi & .118 & .050 & .114 & 2.350 & .019 \\
\hline & MNS & -.165 & .071 & -.222 & -2.318 & .021 \\
\hline & Foursquare & .107 & .052 & .135 & 2.045 & .042 \\
\hline
\end{tabular}

Table 37: Dependent Variable: Services Marketing Tools

\subsubsection{Interpretation}

The $\mathrm{R}$ value in the model summary table shows a simple correlation of 0.952 which shows a high degree of positive correlation. The $\mathrm{R}^{2}$ value shows how much of the total variation in the dependent variable (Services marketing tools for crime prevention and control) that can be explained by the independent variable (use of social media). The table shows that $90.7 \%$ variation in crime prevention can be explained by the activities on social media. This is very high. With a sig (p-value) of (0.000) which is less than Alpha (0.05), this implies that the overall regression model statistically predicts the outcome variable. (That is, it is a good fit). Also, a look at the coefficients table reveals that all the independent variables, apart from WhatsApp connections are significant predictors of the dependent variable. Again, the DW value (1.83) which is greater than the Durbin Watson lower value from table (1.71) means that there is no first order autocorrelation since the value of DW produced by the SPSS lies between the lower and upper values from the critical table.

\subsubsection{Decision}

Since the overall P-value (0.000) is less than Alpha (0.05), that is $0.000<0.05$, and F cal (395) greater than F critical from tables (2.37) we therefore reject the null hypothesis and accept the alternative hypothesis which implies that there is a significant relationship between the activities on social media and the prevention and control of crime among undergraduates in tertiary institutions.

\subsection{Test of Hypothesis Four}

- $\mathrm{HO}_{4}$ : The use of selected advertising media by universities in the fight against crimes has no significant effect on prevention and control of crime among undergraduates.

- $\mathrm{HA}_{4}$ : The use of selected advertising media by universities in the fight against crimes has significant effect on prevention and control of crime among undergraduates.

To test this hypothesis, data presented in tables 13 and 19 were utilized. The SPSS output is as shown below:

\begin{tabular}{|c|c|c|c|c|c|}
\hline \multicolumn{7}{|c|}{ Model Summaryb $^{\text {Model }}$} & R & R Square & $\begin{array}{c}\text { Adjusted R } \\
\text { Square }\end{array}$ & $\begin{array}{c}\text { Std. Error of } \\
\text { the Estimate }\end{array}$ & $\begin{array}{c}\text { Durbin- } \\
\text { Watson }\end{array}$ \\
\hline 1 & $.939^{\mathrm{a}}$ & .881 & .880 & .31369 & 1.80 \\
\hline
\end{tabular}

a. Predictors: (Constant), Television, Billboards, Radio, Newspapers/Magazines

b. Dependent Variable: Services Marketing Tools 


\begin{tabular}{|c|c|c|c|c|c|c|}
\hline \multicolumn{7}{|c|}{ ANOVAa $^{a}$} \\
\hline \multicolumn{2}{|c|}{ Model } & Sum of Squares & $\mathrm{df}$ & Mean Square & $\mathrm{F}$ & Sig. \\
\hline \multirow[t]{3}{*}{1} & Regression & 268.556 & 4 & 67.139 & 682.319 & $.000^{\mathrm{b}}$ \\
\hline & Residual & 36.211 & 368 & .098 & & \\
\hline & Total & 304.767 & 372 & & & \\
\hline
\end{tabular}

a. Dependent Variable: Services Marketing Tools

b. Predictors: (Constant), Television, Billboards, Radio, Newspapers/Magazines

\begin{tabular}{|c|c|c|c|c|c|c|}
\hline \multicolumn{7}{|c|}{ Coefficients $^{a}$} \\
\hline \multicolumn{2}{|r|}{ Model } & \multicolumn{2}{|c|}{ Unstandardized Coefficients } & \multirow{2}{*}{$\begin{array}{c}\begin{array}{c}\text { Standardized } \\
\text { Coefficients }\end{array} \\
\text { Beta } \\
\end{array}$} & \multirow[t]{2}{*}{$\mathrm{t}$} & \multirow[t]{2}{*}{ Sig. } \\
\hline & & $\mathrm{B}$ & Std. Error & & & \\
\hline \multirow[t]{5}{*}{1} & (Constant) & 1.379 & .075 & & 18.285 & .000 \\
\hline & Billboards & .682 & .042 & .881 & 16.054 & .000 \\
\hline & Newspapers/Magazines & -.381 & .091 & -.405 & -4.188 & .000 \\
\hline & Radio & .235 & .080 & .258 & 2.947 & .003 \\
\hline & Television & .194 & .113 & .210 & 1.724 & .086 \\
\hline
\end{tabular}

Table 40: Dependent Variable: Services Marketing Tools

\subsubsection{Interpretation}

The $\mathrm{R}$ value in the model summary table shows a simple correlation of 0.939 which shows a high degree of positive correlation. The $\mathrm{R}^{2}$ value shows how much of the total variation in the dependent variable (Services marketing tools for crime prevention and control) that can be explained by the independent variable (use of selected advertising media). The table shows that $88.1 \%$ variation in crime prevention can be explained by the use of selected advertising media. This is very high. With a sig (p-value) of $(0.000)$ which is less than Alpha (0.05), this implies that the overall regression model statistically predicts the outcome variable. (That is, it is a good fit). Also, a look at the coefficients table reveals that all the independent variables, apart from television advertising are significant predictors of the dependent variable. Again, the DW value (1.80) which is greater than the Durbin Watson lower value from table (1.73) means that there is no first order autocorrelation since the value of DW produced by the SPSS lies between the lower and upper values from the critical table.

\subsubsection{Decision}

Since the overall P-value (0.000) is less than Alpha (0.05), that is $0.000<0.05$, and F cal (687) greater than F critical from tables (2.37) we therefore reject the null hypothesis and accept the alternative hypothesis which implies that there is a significant relationship between the use of selected advertising media by universities and the prevention and control of crime among undergraduates.

\subsection{Test of Hypothesis Five}

- $\mathrm{H}_{5}$ : The use of selected public relations activities by universities has no significant effect on prevention and control of crimes among undergraduates.

- $\mathrm{HA}_{5}$ : The use of selected public relations activities by universities has significant effect on prevention and control of crimes among undergraduates.

To test this hypothesis, data presented in tables 13 and 21 were utilized. The SPSS output is as shown below:

\begin{tabular}{|c|c|c|c|c|c|}
\hline \multicolumn{5}{|c|}{ Model Summary $^{\mathbf{b}}$} \\
\hline Model & $\mathrm{R}$ & R Square & $\begin{array}{c}\text { Adjusted R } \\
\text { Square }\end{array}$ & $\begin{array}{c}\text { Std. Error of the } \\
\text { Estimate }\end{array}$ & Durbin-Watson \\
\hline 1 & $.992^{\mathrm{a}}$ & .985 & .985 & .11249 & 1.70 \\
\hline
\end{tabular}

Table 41

Predictors: (Constant), Use of Internal Magazines, Sports and Recreation, Social Academic Activities, Donation of Vehicles and Furnished Offices, Cafeteria and

Bars, Trade Fairs and Exhibitions, Sponsoring Sporting Activities, Social

Activities' Sponsoring, Donation of Free Buses

a. Dependent Variable: Services Marketing Tools 


\begin{tabular}{|c|c|c|c|c|c|c|}
\hline \multicolumn{7}{|c|}{ ANOVAa $^{a}$} \\
\hline & odel & Sum of Squares & $\mathrm{df}$ & Mean Square & $\mathrm{F}$ & Sig. \\
\hline \multirow[t]{3}{*}{1} & Regression & 300.173 & 9 & 33.353 & 2635.538 & $.000^{\mathrm{b}}$ \\
\hline & Residual & 1994 & 363 & .013 & & \\
\hline & Total & 304.767 & 372 & & & \\
\hline
\end{tabular}

Table 42

a. Dependent Variable: Services Marketing Tools

b. Predictors: (Constant), Use of Internal Magazines, Sports and Recreation, Special Academic Activities, Donation of Vehicles and Furnished Offices, Cafeteria and Bars, Trade Fairs and Exhibitions, Sponsoring Sporting Activities, Social Activities' Sponsoring, Donation of Free Buses

\begin{tabular}{|c|c|c|c|c|c|c|}
\hline \multicolumn{7}{|c|}{ Coefficients $^{\mathbf{a}}$} \\
\hline \multicolumn{2}{|r|}{ Model } & \multicolumn{2}{|c|}{ Unstandardized Coefficients } & \multirow{2}{*}{$\begin{array}{c}\begin{array}{c}\text { Standardized } \\
\text { Coefficients }\end{array} \\
\text { Beta } \\
\end{array}$} & \multirow[t]{2}{*}{$\mathrm{t}$} & \multirow[t]{2}{*}{ Sig. } \\
\hline & & $\mathrm{B}$ & Std. Error & & & \\
\hline \multirow[t]{10}{*}{1} & (Constant) & -.038 & .048 & & -.799 & .425 \\
\hline & Donation of Free Buses & -.116 & .035 & -.132 & -3.349 & .001 \\
\hline & Sponsoring Sporting Activities & .039 & .027 & .040 & 1.418 & .000 \\
\hline & Special Academic Activities & .009 & .023 & .007 & .370 & .711 \\
\hline & $\begin{array}{l}\text { Donation of Vehicles and } \\
\text { Furnished Offices }\end{array}$ & .042 & .024 & .052 & 1.721 & .086 \\
\hline & Social Activities 'Sponsoring & -.016 & .025 & -.019 & -.648 & .517 \\
\hline & Trade Fairs and Exhibitions & .758 & .028 & .769 & 27.175 & .000 \\
\hline & Cafeteria and Bars & .147 & .035 & .159 & 4.211 & .000 \\
\hline & Sports and Recreation & .183 & .027 & .169 & 6.749 & .000 \\
\hline & Use of Internal Magazines & -.036 & .028 & -.043 & -1.304 & .193 \\
\hline
\end{tabular}

Table 43: Dependent Variable: Services Marketing Tools

\subsubsection{Interpretation}

The $\mathrm{R}$ value in the model summary table shows a simple correlation of 0.992 which shows a high degree of positive correlation. The $\mathrm{R}^{2}$ value shows how much of the total variation in the dependent variable (Services marketing tools for crime prevention and control) that can be explained by the independent variable (the use of PR activities). The table shows that $98.5 \%$ variation in crime prevention can be explained by the use of PR activities. This is very high. With a sig (p-value) of (0.000) which is less than Alpha (0.05), this implies that the overall regression model statistically predicts the outcome variable. (That is, it is a good fit). Also, a look at the coefficients table reveals that all the independent variables, apart from use of internal magazine, social academic sponsoring and donation of vehicles are significant predictors of the dependent variable. Again, the DW value (1.70) which is greater than the Durbin Watson lower value from table (1.68) means that there is no first order autocorrelation since the value of DW produced by the SPSS lies between the lower and upper values from the critical table

\subsubsection{Decision}

Since the overall P-value (0.000) is less than Alpha (0.05), that is $0.000<0.05$, and F cal (263) greater than F critical from tables (2.37) we therefore reject the null hypothesis and accept the alternative hypothesis which implies that there is a significant relationship between the use of public relations activities by the universities and the prevention and control of crime among undergraduates.

\subsection{Test of Hypothesis Six}

- $\mathrm{H}_{6}$ : The use of selected publicity activities by universities has no significant effect on prevention and control of crimes among undergraduates.

- $\mathrm{HA}_{6}$ : The use of selected publicity activities by universities has no significant effect on prevention and control of crimes among undergraduates.

To test this hypothesis, data presented in tables 13 and 23 were utilized. The SPSS output is as shown below:

\begin{tabular}{|c|c|c|c|c|c|}
\hline \multicolumn{7}{|c|}{ Model Summary $^{\mathbf{b}}$} \\
\hline Model & $\mathrm{R}$ & R Square & $\begin{array}{c}\text { Adjusted R } \\
\text { Square }\end{array}$ & $\begin{array}{c}\text { Std. Error of the } \\
\text { Estimate }\end{array}$ & Durbin-Watson \\
\hline 1 & $.968^{\mathrm{a}}$ & .936 & .935 & .23031 & 1.76 \\
\hline
\end{tabular}

Table 44

a. Predictors: (Constant), Films and Videotapes, Press Conferences,

Press or News Release, Photographs, Feature Articles

b. Dependent Variable: Services Marketing Tools 


\begin{tabular}{|c|c|c|c|c|c|c|}
\hline \multicolumn{7}{|c|}{ ANOVAa $^{a}$} \\
\hline & Iodel & Sum of Squares & $\mathrm{df}$ & Mean Square & $\mathrm{F}$ & Sig. \\
\hline \multirow[t]{3}{*}{1} & Regression & 285.300 & 5 & 57.060 & 1075.730 & $.000^{\mathrm{b}}$ \\
\hline & Residual & 19.467 & 367 & .053 & & \\
\hline & Total & 304.767 & 372 & & & \\
\hline
\end{tabular}

Table 45

a. Dependent Variable: Services Marketing Tools

b. Predictors: (Constant), Films and Videotapes, Press Conferences, Press or News Release, Photographs, Feature Articles

\begin{tabular}{|c|c|c|c|c|c|c|}
\hline \multicolumn{7}{|c|}{ Coefficients $^{\mathrm{a}}$} \\
\hline \multicolumn{2}{|r|}{ Model } & \multicolumn{2}{|c|}{ Unstandardized Coefficients } & \multirow{2}{*}{$\begin{array}{c}\begin{array}{c}\text { Standardized } \\
\text { Coefficients }\end{array} \\
\text { Beta }\end{array}$} & \multirow[t]{2}{*}{$\mathrm{T}$} & \multirow[t]{2}{*}{ Sig. } \\
\hline & & $\mathrm{B}$ & Std. Error & & & \\
\hline \multirow[t]{6}{*}{1} & (Constant) & -.049 & .089 & & -.556 & .578 \\
\hline & Press or News Release & .673 & .037 & .661 & 18.155 & .000 \\
\hline & Press Conferences & .328 & .034 & .303 & 9.679 & .000 \\
\hline & Feature Articles & -.246 & .079 & -.239 & -3.121 & .002 \\
\hline & Photographs & .070 & .059 & .080 & 1.185 & .237 \\
\hline & Films and Videotapes & .185 & .069 & .186 & 2.688 & .008 \\
\hline
\end{tabular}

Table 46: Dependent Variable: Services Marketing Tools

\subsubsection{Interpretation}

The $\mathrm{R}$ value in the model summary table shows a simple correlation of 0.968 which shows a high degree of positive correlation. The $\mathrm{R}^{2}$ value shows how much of the total variation in the dependent variable (Services marketing tools for crime prevention and control) that can be explained by the independent variable (the use of publicity activities). The table shows that $93.6 \%$ variation in crime prevention can be explained by the use of publicity activities. This is very high. With a sig (p-value) of (0.000) which is less than Alpha (0.05), this implies that the overall regression model statistically predicts the outcome variable. (That is, it is a good fit). Also, a look at the coefficients table reveals that all the independent variables, apart from photographs are significant predictors of the dependent variable. Again, the DW value (1.77) which is greater than the Durbin Watson lower value from table (1.72) means that there is no first order autocorrelation since the value of DW produced by the SPSS lies between the lower and upper values from the critical table

\subsubsection{Decision}

Since the overall P-value (0.000) is less than Alpha (0.05), that is $0.000<0.05$, and F cal $(1075)$ greater than F critical from tables (2.37), we therefore reject the null hypothesis and accept the alternative hypothesis which implies that there is a significant relationship between the use of publicity activities by the universities and the prevention and control of crime among undergraduates.

\subsection{Discussion of Findings}

From the data obtained for this study and the result of the analysis above, the facts that emerged are as follows.

\subsubsection{Nature of Crime Committed By Undergraduates}

The major crimes committed by undergraduates in Nigeria universities are (i) cultism (ii) drug abuse (iii) rape (iv) kidnapping (v) armed robbery (vi) examination malpractices (vii) bank related and cybercrime (VIII) rioting, (IX) stealing (X) prostitution and (XI) assassination. The involvement of undergraduates in these crimes makes them to become monsters to themselves, the University environment and even the larger society. This is because the incidences of undergraduates' involvement in criminal activities are reported in every part of the country and almost on daily basis. Most of these crimes are presented in figure 4.

\subsubsection{Consequences of Undergraduate's Involvement in Crime}

The consequences of this menace of undergraduates' involvement in crime include: (a) many of the undergraduates die as a result of this menace; (b) lecturers and other staff of the universities die as a result of this menace, thus causing the university environment to be unsafe for academic activities; (c) undergraduates attract long terms of imprisonment to themselves and even their parents whom the Police may prosecute for failure to provide necessaries; (d) most of the undergraduates are rusticated from the universities, thus ending the dreams of their parents of producing future leaders for the country; and (e) the undergraduates live in perpetual fear as a result of the crimes they committed in the past, most of them disappear and abandon their educational pursuit even without the knowledge of their parents. 


\subsubsection{Reasons for Undergraduates' Involvement in Crime}

The major reasons why undergraduates commit these crimes are lack of the knowledge of the consequence and constituents of crime. By consequences, we mean that the undergraduates are not aware of the punishments that these crimes attract. Even those that are aware, believe that their parents or relatives will always come to their rescue when they are arrested. Unfortunately, all the crimes mentioned above attract punishment of death or imprisonment for not less than three years and so they are not bail able. By constituents, these undergraduates do not have the knowledge of what constitutes crimes. What constitute crime are stated in page 54 of this study as adopted from chapter 7(a)(b)(c)(d) and 10 of the criminal code Act CAP 77 laws of the federation of Nigeria 1990. Other reasons for undergraduates' involvement in crime are: peer influence, poverty, high cost of acquiring university or higher education, fear of unemployment after graduation, weak parental upbringing, societal decadence, erosion of educational standard, militarization of the Nigeria polity and insecurity within the campus and the country. Most of these reasons are stated in the suggested model for crime prevention and control among undergraduates in Nigeria as presented in figure 4.

\subsubsection{Efforts Made to Curbe Crime among Undergraduates}

Efforts have been made by the management of universities, the government and even the churches to curb the menace of crime among undergraduates, yet the menace persist. Thus, creating a gap which this study strives to close. A summary of these efforts include: (i) strengthening the internal security of the institution; (2) rustication or suspension of undergraduates and recall of certificates issued to graduates that are involved in crime; (3) organizing religious activities for undergraduates; (4) mounting of billboards with messages showing the consequences of crime; (5) using security agencies to arrest and prosecute undergraduates who are involved in crime; (6) enactments of special laws with stringent punishments against crimes committed by undergraduates; and (7) church planting in the campuses, among others.

\subsubsection{Services Marketing Tools for Crime Prevention and Control among Undergraduates}

Prevention and control of crime among undergraduates can be realized through the application of services marketing tools by the universities. These tools include (a) offering high quality education services by the universities; (b) encouraging staff (personnel) to exhibits attitudes that make them the real change agents that they are; (c) posting of good messages aimed at discouraging undergraduates from committing crime through social media Networks; (d) broadcasting messages aimed at discouraging undergraduates from committing crime through selected advertising media; (e) practicing public relations activities aimed at preventing and controlling crime among undergraduates; and (f) practicing publicity activities aimed at preventing and controlling crime among undergraduates. All these services marketing tools must be applied simultaneously for the needed objective to be achieved. The relationship among these tools is contained in table 13 and 14

\subsubsection{Impact of Quality of Education Services (Qes) on Prevention and Control of Crime among Undergraduates}

The quality of education service offered by the universities has positive impact on prevention and control of crime among undergraduates. This is because there is significant relationship between quality of education service offered by the universities and prevention and control of crime among undergraduates. As a result, if the quality of education service is good, it will be easier to prevent and control crime among undergraduates. This satisfies research objective number one and provides answers to research question one. The evidences to these discoveries are as presented in table 15 and 16

\subsubsection{Impact of the Atittude of Staff/Personnel (Asp) on Prevention and Control of Crime among Undergraduates}

The attitude of staff (personnel) of the universities has positive impact on prevention and control of crime among undergraduates. The reason is because there is significant relationship between attitude of staff (personnel) of the universities and prevention and control of crime among undergraduates. This attitude mostly come in the form of regular attendance to class, using teaching methods that fully engage the students, counseling the undergraduates especially with the aim of discouraging them from committing crime, and being friendly to undergraduates at all times. If staff exhibit these traits, they would have contributed to the prevention and control of crime among undergraduates. Hence, this satisfies research objective two and also provides answers to research question 2 . The evidences of these discoveries are presented in table 17 and 18 .

\subsubsection{Impact of the Use of Social Media Network (SMN) on Prevention and Control of Crime among Undergraduates}

Posting of messages aimed at prevention and control of crime through the social media networks by the universities have positive impact on the prevention and control of crime among undergraduate. The reason is because there is significant relationship between messages on social media Networks and prevention and control of crime among undergraduates. The most accessible social media networks to undergraduates in Nigeria are Facebook, twitter and WhatsApp. But based on the analyses, Facebook and twitter are the most appropriate for prevention and control of crime among undergraduates. Almost every undergraduate have access to these social media networks through their handsets and GSM networks. Therefore, every message posted through these networks will reach the undergraduates within seconds; thus making the networks veritable tools for communication between the universities and the undergraduates especially in the area of prevention and control of crime among undergraduates. This satisfies the study objective three and also answer's research question three. Evidences to these discoveries are presented in tables 19 and 20. 
4.4.10. Relationship between the Use of Sellected Advertising Media and Prevention and Control of Crime among Undergraduates

Disseminating message aimed at discouraging undergraduates from committing crime by universities through selected advertising media such as Radio, television, Newspapers/magazines and Billboards can prevent and control crime among undergraduates to a very high extent. This is because there is a significant relationship between the use of these selected advertising media for disseminating messages against undergraduates' involvement in crime. But result of the analyses gave more support for the use of radio, newspapers and magazines. With this, the study objective four is realized. Also, it provides answers to the research question four. The evidences to these discoveries are presented in figures 4.6 and 22.

\subsubsection{Relationship between the Use of Sellected Public Relations Activities and Prevention and Control of Crime among} Undergraduates

The use of public relations activities by the universities can to a high extent contribute to the prevention and control of crime among undergraduates. This is because the use of public relations activities by the universities has significant relationship with the prevention and control of crime among undergraduates. The public relations activities that can realize this objective are: (1) donating free buses to students to ease transportation problems; (2) sponsoring of sporting activities among undergraduates with huge financial rewards to winners; (3) sponsoring special academic activities among undergraduates such as essays and quiz competition, science and technology competition or exhibition both locally and overseas with huge financial rewards. (4) sponsoring or attracting trade fairs and exhibitions in the universities with students as sales persons to the participating firms; (5) donation of cafeteria where food and soft drinks are sold to students at subsidized prices; and (6) building and donating sports and recreation facilities to the students. By so doing the study objective five have been realized, while answers to research question five have also been provided. The evidences to these discoveries are as presented in figures 4.7 and 24

\subsubsection{Relationship between the Use of Publicity Activities and Prevention and Control of Crime among Undergraduates}

The use of publicity activities by the universities can to a high extent contribute to the prevention and control of crime among undergraduates. This is because the use of publicity activities by the universities has significant effect on prevention and control of crime among undergraduates. The publicity activities that can realize this objective are; news releases, feature articles, and films or videotapes. All these must carry messages aimed at discouraging undergraduates from getting involved in crime. By so doing, the research objective number six have been realized while answers to research question six have been provided. The evidences to these discoveries are as presented in tables 25 and 26

\subsubsection{Demographic Characteristics of Respondents}

Both sexes were represented in the responses (46.4\% and 53.6\%) for male and female respectively. Majority of respondents $(71 \%)$ fall within the age bracket of 21-25 years, therefore they fall within the definition of youths and are still very young. Majority $\left((88.7 \%)\right.$ of the respondents are undergraduates that are in $2^{\text {nd }}$ to $4^{\text {th }}$ years in the universities. This means that the respondents are experienced enough to understand and proffer solutions to the problem of this study; hence, their responses are reliable. The data showing evidences for these are presented in tables 27 and 28

\section{Summary, Conclusion and Recommendations}

\subsection{Preamble}

The major objective of this study is to identify the reasons why undergraduates in Nigeria tertiary institutions commit crime, as well as to determine how service marketing tools can be applied to prevent and control crime among these undergraduates. This chapter articulates the findings from data obtained for the study. This will necessitate the drawing of conclusion and making of recommendations.

\subsection{Summary of Major Findings}

From the discussion above, the major findings in this study are:

- the reasons why undergraduates commit crimes are lack of the knowledge of the consequences and constituents of crime, peer influence, poverty, high cost of acquiring higher education services, weak security within the campuses, fear of unemployment after graduation, greed, weak parental upbringing, societal decadence, erosion of education standard and militarization of the Nigeria polity;

- the quality of education services by the universities to a high extent contribute to prevention and control of crime among undergraduates;

- the attitude of staff (personnel) of the universities contributes to a high extent to the prevention and control of crime among undergraduates;

- the use of social media networks to a high extent contribute to the prevention and control of crime among undergraduates;

- the use of selected advertising media to disseminate messages aimed at discouraging crime among undergraduates contributes to prevention and control of crime among undergraduates to a high extent;

- the use of selected public relations activities by the universities aimed at discouraging undergraduates' involvement in crime contributes to the prevention and control of crime among undergraduates to a high extent; and 
- the use of publicity activities by the universities with messages aimed discouraging undergraduate's involvement in crime contributes to prevention and control of crime among undergraduates to a high extent.

\subsection{Conclusion}

From the facts that emerged so far, undergraduates' criminal behavior is as a result of factors such as: peer group influence, poverty or hardship, lack of knowledge of the consequences of crime, high cost of acquiring higher education service, lack of security within the campuses, greed and quest to maintain social class by students, weak parental upbringing, societal decadence, erosion of educational standard, militarization of the Nigeria polity, frustration by academic staff and betrayal by loved ones. The fact also proves that these social economic problems can be remedied by the universities with the application of services marketing tools such as providing high quality education services, encouraging staff to act as change agents by counseling and fully engaging the students with academic activities, posting messages aimed at prevention and control of crime among undergraduates to the social media networks, disseminating information aimed at prevention and control of crime among undergraduates through selected advertising media, practicing selected public relations activities aimed at prevention and control of crime among undergraduates and practicing selected publicity activities aimed at prevention and control of crime among undergraduates The strategies to achieve this are the bases of the researchers' recommendations as stated below.

\subsection{Recommendations}

Given the discussion of findings that emerged for this study, the researcher recommends as follows:

- The Quality of education services (QES) rendered by the tertiary institutions must be improved. This improvement should take the following forms:

- Reliabilty: the services must be dependable (ability to provide knowledge and skill), show great benefits to undergraduates and less costly.

- TANGIBLES: the universities must provide physical facilities such as laboratories, libraries, electricity supply, conducive class rooms and learning environment.

- Responsiveness: steps taken by undergraduates to receive the services should be short and such that gives the undergraduates prompt response to their enquiries or complaints and easy and prompt access to the facilities.

- Assurance: the services should have the ability to convey trust, confidence, and competence to the undergraduates in a courteous manner.

- EMPATHY: the services should have the ability to give caring, friendly and individualized attention to the undergraduates. All these variables are denoted as QES

- (2) Staff of universities are the major contact point between the students and the tertiary institutions. Academic staff are the main change agents in an education service. By so doing, how they deliver their services determine how the target adopters (undergraduates) adopt to the needed change which is crime prevention and control among undergraduates. Therefore, the researcher recommends that the attitude of staff (personnel) of the institutions must change. This needed change should be in the following forms:

$>$ Regular attendance to class by lecturers;

$>$ Using teaching methods that are good and keep undergraduates very busy;

$>$ Giving undergraduates easy and free access to their results;

$>$ Staff always wearing a friendly mood before undergraduates; and

$>$ Ability of staff to act as change agents to undergraduates through counseling.

These recommended variables in the attitude of staff are denoted as ASP.

- Universities should utilize the positive impact of Social Media Network as a superlative marketing communication tool to prevent and control crime among undergraduates. To realize this, messages carrying the consequences and constituents of crime can be posted through these social media Networks. And in seconds, these massages will get to every undergraduate in the world. One of the reasons why students get involved in criminal activities is their lack of knowledge of the consequences and constituents of crime. Therefore, through these social media networks, students will have adequate knowledge on the consequences and constituents of crime. The most popular social media networks used by undergraduates in Nigeria are: Facebook, skype-twitter, 2-go, WhatsApp, Yahoo, and MNS. But based on the findings of this study, only Facebook and Twitter are recommended for use by the universities for prevention and control of crime among undergraduates. They are denoted as SMN.

- The tertiary institutions should utilize the power of advertising media to dissimilate information about the consequences of crime, and even activities or behaviours that constitute crime. Apart from not having knowledge about the consequences of crime, undergraduates do not have adequate knowledge of what constitutes crime. Hence, they get involved in criminal activities unknowingly. Based on the study findings, the researcher recommends the use of newspapers, magazines, and radio. These recommended advertising media are denoted as ADM.

- Tertiary institutions must renew their efforts and practice the following public relations activities:

$>$ Donating free buses to ease students' transportation problems.

- $\quad$ Sponsoring of sporting activities among undergraduates with huge financial rewards to winners.

$>$ Sponsoring special academic activities among undergraduates such as essays, and quiz competition, science/technology competitions and exhibitions both locally and overseas. 
$>$ Sponsoring trade fairs and exhibitions in the institutions with undergraduates as sales persons to the participants.

$>$ Donation of cafeteria and bars where foods and soft drinks are sold to the undergraduates at subsidized prices.

- Building and donating sports and recreation facilities to the undergraduates.

- These recommended public relations activities are denoted as PRA.

- Also, universities must rediscover the importance of publicity activities in boasting the image of the organization. These tools can also be utilized for disseminating information aimed at prevention and control of crime among undergraduates. To achieve this, the university should practice the following publicity activities: News releases, Feature articles and showing of films and videotapes. These recommended publicity activities are denoted as PRB.

\subsection{Contribution to Knowledge}

Before now, some services and social marketing models have existed for changing behaviors that are inimical to societal wellbeing. Some of these models are cited in figure 3 of this study. Apart from its complexity or difficulty to comprehend, the models are unable to identify the needs of the target adopters before suggesting how to change the behavior of target adopters. Furthermore, the models fail to give reasonable credence to reasons behind the deviant behavior of target adopters. Specifically, the models are silent in prevention and control of crime among undergraduates which in this case is an innovation. The researcher's postulation in figure 4 is reliable, but because of the findings that emerged after analysis of data, more facts emerged about the actual services marketing activities that are capable of preventing and controlling crime among youths in tertiary institutions. Because of these emerging service marketing activities for prevention and control of crime among undergraduates, a new model is developed. The new model is represented in a formula thus:

- $\quad \mathrm{UCB}=\mathrm{F}(\mathrm{QES}, \mathrm{ASP}, \mathrm{SMN}, \mathrm{ADM}, \mathrm{PRA}, \mathrm{PBA})$

- Where UCB = Undergraduate Criminal Behavior

- $\quad$ QES = Quality of Education Services

- $\quad$ ASP $=$ Attitude of staff/Personnel of tertiary institutions
- $\quad \mathrm{SMA}=$ Social media Network

- $\mathrm{ADM}=$ Advertising media activities.

- $\quad$ PRA = Public relations activities.

- $\quad$ PBA $=$ Publicity activities

This model is however represented in a diagram as shown in figure 7 below:

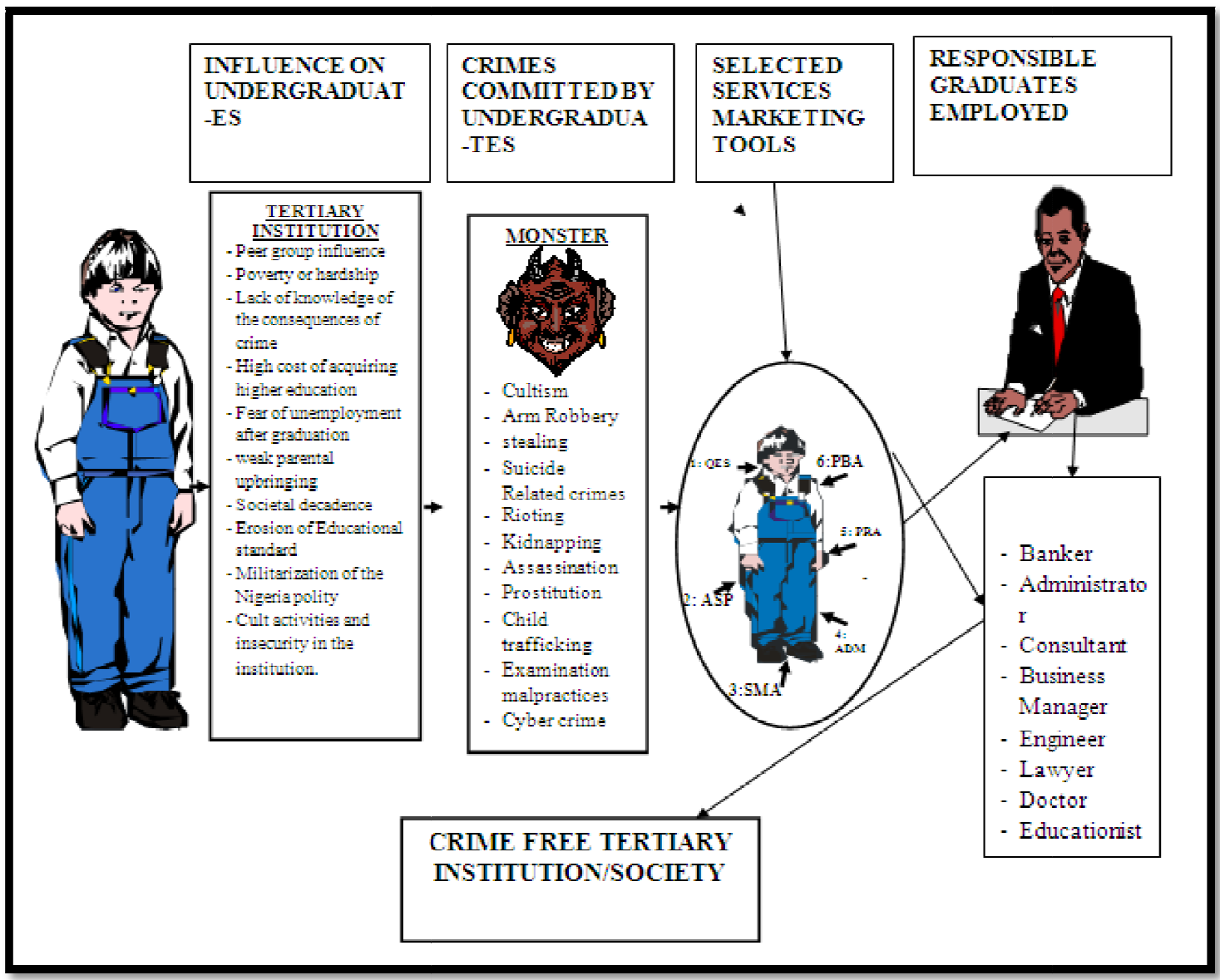

Figure 7: Amplified Model for Preventing and Controlling Crime Among Undergraduates through Service Marketing

Source: Researcher's Desk (2015) 
This amplified model is as simple as it looks. A youth gains admission into a tertiary institution with high aspirations of graduating into a profession after a stipulated period. Unfortunately, as soon as he/she resumes academic activities, he/she is exposed or overwhelmed by existing evils or factors such as: peer group influence, poverty or hardship, lack of knowledge of the consequences and constituents of crime, high cost of acquiring higher education, lack of sanity within the campuses, fear of unemployment after graduation, greed and quest to maintain social class by undergraduates, weak parental upbringing, societal decadence, erosion of educational standard, militarization of the Nigeria polity, cult activities and general insecurity within the campuses. Because of these evils, the undergraduate becomes frustrated. To overcome this frustration, the undergraduate exhibits behavior that proves his defense mechanisms. Thus he becomes a monster to both himself and his environment. As a result, he begins to commit crimes such as: cultism, armed robbery, stealing, suicide related offences, rioting, kidnapping, cyber related crime, assassination, prostitution, child trafficking and examination malpractices among others. Fortunately, if this monster is exposed to services marketing activities such as recommended (denoted as QES,ASP, SMN, ADM, PRA PBA), he/she becomes a changed person and graduates into a professional such as: banker, administrator, consultant, business manager, engineer, lawyer, doctor, educationist, Scientist and other professionals. Thus, he begins to contribute to the social-economic development of this country. Most importantly, these services marketing activities must come in the following forms: (1) ensuring that the quality of educational services offered by the universities is reliable, responsive and less costly in a conducive learning environment as recommended; (2) attitude of staff (personnel) of the university should take the form of regular attendance to classes, using teaching methods that fully engage the undergraduates, give undergraduates easy and free access to their results, always wearing a friendly mood and counseling of students to stay out of criminal activities; (3) utilization of opportunities offered by the Social Media Networks such as: Facebook and twitter; (4) use selected advertising media such as Newspapers, magazines, and radio to disseminate information about the consequences and constituents of crime among undergraduates; (5) practice recommended public relations activities; and (6) practice recommended publicity activities.

\subsection{Limitations of the Study}

The researcher experienced some setbacks and barriers while gathering data for this study. Prominent among these barriers are:

- The inability to contend with the vagaries of policing services in Nigeria while executing this study was enormous. Within the period of this study, the Nigeria police was experiencing turbulent moments with regards to increasing insurgent or terrorist activities, armed robbery, kidnapping, political crises and communal clashes. This made every police officer including the researcher to be busy with crime prevention and control. Therefore, making time a major constraint for this study.

- Secondly, given the proximity of the researcher's research area (five south-eastern states in Nigeria), accessing the respondents in all the universities selected for the study was cumbersome. The researcher needs to be around when the students are in the classes for lecture so as to access them. Though the interest and response from the students was fascinating, it was very costly to obtain their responses. Thus, cost is another major constraint for this study. Nevertheless, the researcher was able to overcome these challenges. The effort of the researcher was galvanized by the assistance of friends who are academic staff in the universities used for the study.

\subsection{Areas for Further Research}

Given the insight gathered through this study, the researcher is suggesting that other researchers can execute similar studies by employing the following modifications and approaches.

- Other researchers can carry out studies to identify new or more variables that contribute to quality of education services in Nigeria. This will enable researchers identify further the extent of relationship between quality of education services by tertiary institutions and crime prevention and control among undergraduates.

- The social media network is an emerging communication tool for marketing. The result of this study is silent on how and when to post messages to the internet by the tertiary institutions and even how to develop these messages. It is therefore the suggestion of the researcher that other researchers can carry out studies on better ways to use the social media network for crime prevention and control among undergraduates or any other commercial and non-commercial endeavor.

- This study is conducted in Nigeria which is a developing country. It is the suggestion of the researcher that other researchers can carry out this study in developed countries like the United States of America (USA), Canada, and United Kingdom where student's involvement in crime is high despite their huge economic potentials and political stability.

\section{References}

i. Aaker, D.A., Kumar, U. and Day, G.S., (1998); Marketing Research, $6^{\text {th }}$ ed., New York, John Wiley and Sons, Inc.

ii. Abia State of Nigeria (Laws number 10 of 2009): Laws to prohibit Terrorism, Kidnapping, Hostage taking, the use of offensive weapons or explosives and other threatening behavior and for matters related thereto.

iii. Abubakar, A. (2010); IBB wanted to rule for life, Lagos, This day August 25.

iv. Achumba, I.C (2007); Corporate Governance, Marketing and National Transformation: A Conceptual frame work, Lagos, The Academy of Marketing Journal, vol.1 No.1

v. Adebayo, B. (2006); Troubled Varsities, Lagos, The News Magazine, 21 ${ }^{\text {st }}$ August. 
vi. Adebayo, A.A. (2013); Youths' unemployment and crime in Nigeria: A nexus and implications for national development. International Journal of Sociology and Anthropology. Vol.5 (B), PP.350-357

vii. Ademola, F. (2010); Youths are against electoral fraud violence, Lagos, The Nation Newspapers, July 16.

viii. Adepegba,A. (2011); Police Arrest 51 students over Election Violence. The Punch, Saturday, $23^{\text {rd }}$ April.

ix. Adewale,R. (2005);Violence in the Citadel: The menace of secret cults in the Nigeria Universities. NORDIC Journal of African Studies,14(10), 79-98.

x. Adesayo, B. (2000); Troubled Varsities, Lagos, The News Magazine, August 21.

xi. Agbonifoh, B.A, Ogwo E.O, Nnolim D.A, and Nkamnebe D.A, (2007); Marketing in Nigeria: Concepts, Principles and Decisions, $2^{\text {nd }}$ ed, Aba Afritowers Books

xii. Agbo, N. (2012); Pain in the Dress: Many Institutions have come up with measures to curb indecent dressing to no avail, Lagos, The Nation (campus life), February 23.

xiii. Aham, U. (2000); Scuttled mission: Undergraduates protest deplorable condition in Universities, Lagos, The News, August 21.

xiv. Aimiuwu, L. (2009); Nigeria Can, Lagos, National Institute of Marketing of Nigeria.

xv. Ailemen, D. (2013);Are Private Universities hopes of tertiary institutions in Nigeria.Lagos, The Nation,Thursday,May 16.

xvi. Ajayi, A., Ekundayo, H. and Osalusi, F. (2010); Menace of Cultism in Nigeria Tertiary Institutions A., (1994); A:The way out, The Anthropologist,12 (3)

xvii. Akor,A (1994); Malignant Cult Epidemic, Lagos, The GUARDIAN NEWSPAPERS $20^{\mathrm{TH}} \mathrm{MARCH}$.

xviii. Aliu, A. (2010); Edo inaugurates Youths Entrepreneurship Scheme, Lagos, The Guardian, November 23.

xix. Amuta, C. (2009); Under the Gun, Lagos, This day, June 11.

xx. Anya, O.A. (2009); Leaders to focus on youths education, Lagos, This day December 31 st.

xxi. Andersen, A. R. (1995): Marketing Social Change: Changing Behavior to promote

xxii. Health and Social Development. The Environment.

xxiii. Anyanwu, A. (2012); Political Marketing as Instrument of improved Governance in Nigeria, $9^{\text {th }}$ Inaugural Lecture, Imo State University, Owerri

xxiv. Anyanwu, A. and Nwokah G.N. ed (2008); Contemporary Book on Services Marketing, Owerri, Avan Global Publications.

xxv. Anyanwu, A. (2000);Research Methodology in Business and Social Sciences. Owerri: Avan Global Press.

xxvi. Anyanwu, A. (2003); Promotional Strategy: A Schematic Approach, Owerri: Avan Global Press.

xxvii. Ahigbuo, C.C. (2005); Guide to project Research Writing. Owerri: Peace Publication.

xxviii. Ayodele,J.O. and Aderinto, A.A. (2014); Nature of Crime and Crime reporting of victims in Lagos Nigeria. International Journal of Criminology and Sociological Theory, Vol. 1 December.

xxix. Baridam, D.M. (1995); Research Methods in Administrative Sciences, 2nd ed., Port Harcourt Paragraphics.

xxx. Bassey. O. (2011); Six Students arrested over the murder of House Aspirant, Lagos This day, January 24th.

xxxi. Belch, G.E. and Belch, M.A. (2007); Advertising and Promotions: An Integrated Marketing Communication Perspective, $7^{\text {th }}$ ed ., Boston Burr Ridge, McGraw-Hill Irwin

xxxii. Belo-Osagie, K. and Kanebe, M. (2012); Student's Unionism in Universities, Lagos The Nation, February 23rd.

xxxiii. Berenson, M. L. and Levine, D.M. (1986); Basic Business Statistics: concepts and Applications, 3rd ed., New York, Prentice-Hall International Editions.

xxxiv. Berry, L. and Parasuraman, A (1991); Marketing Services: Competing Through Quality, New York, the Free Press.

xxxv. Bisong, R. (2010); The Media and Kidnapping Reports, Abuja, The Dawn Newspaper, August $8^{\text {th }}$.

xxxvi. Bitner, M.J. (1990); Evaluating Service Encounter: The effect physical surroundings and employee responses, Journal of marketing, Vol.54, pp 69-82.

xxxvii. Blank,C (2010); Consumer Perception Theory. WWW.Smallbusness.chrom.com

xxxviii. Blunch, N.J. (2013) Introduction to structural equation modelling using IBM SPSS statistics and AMOS.London: Sage Publishers Limited.

xxxix. Blythe, J. (2003); Marketing Strategy, London, McGraw-Hill Education.

xl. Bowersox, D.J and Cooper, M.B (1992); Strategic Marketing Channel Management, New York McGraw-Hill ING.

xli. Belch, G.E. and Belch, M.A. (2007); Advertising and Promotions: An Integrated Marketing Communication Perspective, $7^{\text {th }}$ ed ., Boston Burr Ridge, McGraw-Hill Irwin

xlii. Brassington, F. and Pettit, S. (2006); Principles of Marketing $4^{\text {th }}$ ed, Harlow England, Prentice Hall (Financial Times).

xliii. Brandt, D.R (2008); Getting more from the voice of the Customer, Journal of Marketing Management, November/December, vol. 17, No. 6, American Marketing Association.

xliv. Brett R. (2009); Encarta Dictionary and Encyclopedia, Microsoft Incorporated..

xlv. Bursik, R. and Grasmick, H. (1993); Neighborhoods and Crime: The Dimension of effective community control, New York Lillington Books.

xlvi. Burns, A.C. and Bush, R.F. (1998); Marketing Research, Englewood Cliffs, New Jersey, Prentice Hall.

xlvii. Clark, R.V. (1997); Situational Crime Prevention: Successful Case Studies, 2nd ed., Harrow and Heston, New York, pg. 2

xlviii. Chapman, D. and Cowdell, T. (1998); New Public Sector Marketing, London, Financial Times (Pitman Publishing).

xlix. Chaipoopirutana,S (1990); The development and measurement of different services quality model. Journal of marketing, Vol.54, 45-51. 
l. Chukwu, A. (2011); The Contributions of the youths to our deteriorating society, Owerri, The Leader, July 10.Constitution of the Federal Republic of Nigeria, 1999 as amended.

li. Chapman, D. and Cowdell, T. (1998); New Public Sector Marketing, London, Financial Times (Pitman Publishing).

lii. Chukwuemeka,D. (2012); Cultism in Nigeria Higher Institutions: Response of the Church WWW. Cultisem in Nigeria and the Church. (Retrieved)

liii. Chakrapani, C., Glaser, P., Chadwick, S. and Shearer, C. (2008); where have all the Respondents gone. Journal of Marketing Research, Writer.

liv. Cravens, D.W and Piercy, N.F (2003); Strategic Marketing, $7^{\text {th }}$ ed, Boston Burr ridge, McGraw-Hill Irwin.

lv. Criminal Code Act Cap 77 Laws of the Federation of Nigeria 1990.Dancey, and Reidy (2004);

lvi. Deal, K. (2009); More than meets the eye; SYSTAT 12 offers surprises and pitfalls for Researchers. Journal of Marketing Research, Spring.

lvii. Dimeji, B. (2010); Nigeria loses one Trillion Naira Unspent Fund Annually to Corruption, Lagos, This day, August 25.

lviii. Duboff, R.S (2009); Taking the long view: The mindset of a recession is a good time for Marketers to produce a long term measurement plan, Journal of Marketing Management, May/June, volume 18 No.3, American Marketing Association.

lix. Dunne, P. and Lusch, R.F (1999); Retailing, 3rd ed. Fort Warth, The Dryden Press.

lx. Effiong, J. (2013); Two UNIUYO Killed, as Students protest fees increase, Lagos The Sun Newspaper ,June 13

lxi. Ehiede, D.0 (2007); Policing Nigeria in the $21^{\text {st }}$ Century, Ibadan, Spectrum Books LTD. )

lxii. Ezejelue, A.C., Ogwo, O.E., and Nkamnebe A.D., (2008); Basic principles in managing Research Projects, 2nd ed., Aba, Afritowers LTD.

Ixiii. Fatai, J.O. and Adejuwo, K.O. (2011); Conflict and Conflict Management in Tertiary

lxiv. Institutions: The case OF Nigeria Universities. European Journal of Humanities and Social Sciences,Vol. 7 No 1 (Special issue).

lxv. Finn,D.W and Lamb,C.W. (1990); An evaluatin of the SERVQUAL Scales in Retailing setting.Advances in consumer research,VOL. 18,PP. 483-490

lxvi. Fraser, C. (1990); Harnessing the Power of Ideas: Communication and Social Mobilization for UNICEF-Assisted Programmers, New York United Nations Children's Fund. (UNICEF)

lxvii. Futrell,C.M. (2006); Fundamentals of Selling: Customer for life through Services, $9^{\text {th }}$ ed. Boston Burr Ridge McGraw-Hill Irwin.

lxviii. Gbotbabadi,R.A,Feiz,S.,Baharun, R. (2015); Service Quality Measurements. A Review.Millenum Journal of Academic Research in Business and Social Sciences, February, VOL 5,No 2 pp 267-285.

lxix. Green, P.E. and Tull, D.S. (1978); Research for Marketing Decisions, $4^{\text {th }}$ ed., Englewood Cliffs, New Jersey, Pretence - Hall Inc.

lxx. Hair, J. F., Bush, R. P. and Ortinau, D.J. (2003); Marketing Research: within a changing information Environment, Boston Bur ridge McGraw - Hill Irwin.

lxxi. Hair, J.F., Bush, R.P. and Ortinau, D.J. (2006) Marketing Research. New York: McGraw Hill/Irwin.

lxxii. Hair, J.F.; Black, W.C.; Babin, B. J.; \& Anderson, R.E. (2010);Multivariate data analysis (7th Edition). New Jersey: Pearson Prentice Hall.

lxxiii. Haldeman, T and Turner J. (2009); Implementing a Community Based Social Marketing Programme to increase recycling, Social Marketing, Quarterly, 15(3).

lxxiv. Harvey, P. D. (1999); Let every child be wanted: How Social Marketing is revolutionalizing contraceptives used around the world. Auburn House

lxxv. Hasting, Gerard (2007); Social Marketing: Why should the Devil have all the best

lxxvi. times, Butterworth-Heinemann

lxxvii. Hawkins, D.I, Best R.J and Coney K.A (2001); Consumer Behavior: Building Marketing Strategy, Boston Burr Ridge, Irwin McGraw-Hill Irwin.

lxxviii. Hon,W (2000); An overview of customer satisfaction model,RP Group proceeding. 101-109

lxxix. Inyanga, J.I.N and Anyanwu, A. (2006); Marketing and Society, Owerri, Avan Global publications.

lxxx. Jain,P and Aggarwal,V.S (2015); Service Quality Models: A review, Journal of management Research,VOL. 7 Issue 2,October.

lxxxi. Jobber, D. (2004); Principles and Practice of Marketing, $4^{\text {th }}$ ed, London McGraw-Hill Companies.

lxxxii. Jibril, S.N (2007); Ethics for Development, Abuja, Kingspet Communications.

lxxxiii. Kalu, S.E (1998); Marketing and Society, Port-Harcourt, Markowitz Centre for Research and development.

lxxxiv. .Kalu, S.E and Awa, H.O (2007); Public Sector Marketing in Developing Economies: The Nigeria Experience, Lagos, The Academy of Marketing Journal vol.1 No.1.

lxxxv. Kaplan, A. M., Haenlein, M. (2009); The Increasing Importance of Public Sector Marketing: Explanations, Applications and limits of Marketing within Public Administration, European Management Journal, winter.

lxxxvi. Kennedy, A. (2010); Using community based social marketing techniques to enhance environmental and regulation sustainability. Journal of Psychological Sciences, 2(4).

lxxxvii. Kotler, P. and Amstrong, G. (2005); Principles of Marketing, $11^{\text {th }}$ ed, New Delhi India Prentice Hall LTD.

lxxxviii. Kotler, P., Bowen, J.T. and Makens, J.C (2006); Marketing for Hospitality and Tourism, $4^{\text {th }}$ ed, Australia, Pearson Education LTD.

lxxxix. Kotler, P. and Keller K. (2006); Marketing Management, 12th ed, New Delhi India Pearson Education. 
xc. Kotler, P. and Roberto E.L (1989); Social Marketing: Strategies for Changing Public Behavior, New York, The Free Press.

xci. Kotler, P., Roberto N. and Nancy L (2002); Social Marketing: Improving the Quality of life, New York, Saga Publication.

xcii. Krasner, L. and Ullmann, L.P (1973); Behavior Influence and Personality: The social matrix of Human Action, New York, Holt, Rinehart and Winston, Inc.

xciii. Lefebvre, R.C. (2006); “Hello Jupiter, Anyone Home?” On Marketing and Social Change, Journal of Marketing Management, winter.

xciv. Lefebvre, R.C., Flora, J.A. (1988); Social Marketing and Public Health Intervention

xcv. (Portable Document Format), Journal of Health Education Quarterly, 15 (3).

xcvi. Lovelock,C. and Wirtz, J. (2011);Services Marketing: $\quad$ People,Technology and Strategy. Upper Saddle River,New Jersey,Prentice Hall

xcvii. Madu, J.E. (2012); Marketing the Police 2, Owerri ,Oscar Graphics

xcviii. Miscellaneous Offences Act chapter M17, Laws of Nigeria, 2004 as Amended.

xcix. Mafuyai, H.B (2012); Why Nigeria Varsities fail World Ranking, Lagos, The Nation, February 23.

c. Makanjuola, R. (2000); There is Nothing To Fear. The News Magazine, $21^{\text {st }}$ August.

ci. Mason, C.H and Perreault, W.D (2002); The Marketing Game, $3^{\text {rd }}$ ed, Boston Burr Ridge, MC Graw-Hill.

cii. Marenin,O. and Reisig, D.M (1995); A General Theory of Crime and Patterns of Crime in Nigeria: An Exploration of Methodological Assumptions. Journal of Criminal Justice, Vol.23 No.6. pp 501-518

ciii. McCarthy, E.J (1975); Basic Marketing: A managerial Approach, $5^{\text {th }}$ ed, Home Wood, Illinois Richard D. Irwin Inc.

civ. McKenzie-Mohr, D. (2000); Fostering Sustainable Behavior Through Community Based Social Marketing, Journal of American Psychologist, 55(5)

cv. McKenzie-Mohr, D, William S. (2008); Fostering Sustainable Behavior; An Introduction to Community Based Social Marketing, European Management Journal, Summer.

cvi. Momodu, D. (2010); The Ugly Face of Poverty, Lagos, This day, August 8.

cvii. Moss, P. (1994); Can there be validity without reliability? Journal of Educational Research.

cviii. Nevadosonsky,J.J. (1985); Drug use among University Students: Prevalence of self-reported use and attitude to use. United Nations Office on Drugs and Crime

cix. Nkanga, E. (2011); World Cyber Crime: Nigeria Ranks 65 th , Lagos, This day, April 18.

cx. Neiger, B. L., Rosemary T., Michael D. B., and McKenzie J.F (2003); Positioning Social Marketing as a Planning Process for Health Education (HTML), American Journal of Health Studies 18 (2/2).

cxi. Nevadomsky,J.J. (1985); Drug use among Nigeria University Students: Prevalence of self-reported use and attitude to use. United Nations Office on Drugs and Crime.

cxii. Nkamnebe, A.D (2003); Theorizing in Marketing: How possible and feasible? Business Review, vol.3 No.3, Faculty of Business Administration, Abia State University Nigeria

cxiii. Nnabugwu,F (2015); Five Nigerian students detained in Malaysia over alleged \$125.2 million Internet Scam. Lagos, Vanguard Newspaper.

cxiv. Nunnaly, J. (1978) Psychometric Theory. New York: McGraw Hill.

cxv. Nwaezeh, K. (2006); 24 Youths arrested over killing of DPO, Inspector, Others, Lagos. This day, Saturday 16.

cxvi. Nwaizugbo, I.C (2010); An Appraisal of the Application of Marketing Concept to Marketing Education Delivery in Nigeria, Enugu, Nigeria. Journal of Marketing, Department of Marketing, University of Nigeria Enugu campus.

cxvii. Nwokah, G.N (2007); Marketing in Governance: Transformational Marketing Model, Lagos, The Academy of Marketing Journal, vol.1 No.1.

cxviii. Nzeshi, O. (2009); Abudulmutallab: Nigerian Muslims condemn Terrorism The Nation Newspaper, August 25.

cxix. Nwaezeh, K. (2006); 24 Youths arrested over killing of D.P.O., Inspector and Others, Lagos, This day October 16.

cxx. Ogwo, O.E. (2008); Marketing and Vision 2020: Challenges and Prospects, Lagos National Institute of Marketing of Nigeria.

cxxi. Obijiofor, L. (2016);Universities as Nest of criminals. WWW.nigeriavillagesquare.com

cxxii. Ogwo, E.O. and Nkamnebe A.D. (2009); Marketing in Nigeria's Development: Festschrift in honor of Prof. Julius Onuora Onah, Nimo Anambra State, Rex Charles and Patrick LTD.

cxxiii. Onah, J.O. (2007); Consumer Behaviour: a PhD Lecture Note, Department of Marketing Abia State University, Uturu

cxxiv. Onyetunde, T. (2000); Receding Wave of Cult Violence, Lagos, Tell Magazine, August $28^{\text {th }}$.

cxxv. O'Shaughnessy, J. (1992); Explaining Buyer Behavior: Central Concepts and Philosophy of Science Issues, New York, Oxford University Press Inc.

cxxvi. Ogwo, E.O. (2009); Services Marketing: A Ph.D Lecture Note, Department of Marketing, Abia State University, Uturu.

cxxvii. Ogwo, E.O. (2008); Marketing and Society's development: Thesis, Anti-thesis and synthesis, 9th Inaugural lecture of Abia State University, Uturu

cxxviii. Ogwo, E.O. and Nkamnebe A.D ed. (2009); Marketing in Nigeria's Development: Festschrift in Honor of Professor Julius Onuora Onah, Nimo, Rex Charles and Patrick LTD.

cxxix. Ogiedefa, I (2008); Cultism in Educational Institutions in Nigeria:Causes,Pssible Solutions and Counselling Implications. WWW.devifinder .com

cxxx. Ogundare, F. (2010); As Sexual Harassment Cases in Tertiary Institutions get Messier, Lagos, This day, August 25. 
cxxxi. Ogunbameru,0. (2004); Personality Dimentions to Cultism in Nigeria Tertiary Institutions:A Socialogical Perspective. Journal of Human Ecology, 16(2), 91-98.

cxxxii. Oguntuase, B. (1999); Cultism and Violence in Higher Institutions of Learning in Nigeria,University of Lagos,AntiCult week,Nov. 3.

cxxxiii. Ojedokun,U.A. and Eraye, M.C. (2012);Social-economic lifestyles of the Yahoo-boys:A study of perceptions of university students in Nigeria. International Journal of Cyber Criminology,Vol.6 Issue 2,July-December

cxxxiv. Oji, C., Dike M and Bello M. (2012); Facebook Murder: why we killed Cynthia, Lagos, Daily Sun, August 23.

cxxxv. Okeshola,F.B. and Adeta,A.K. (2013); The Nature,Causes and Consequences of Cyber Crime in Tertiary Institutions in Zaria-Kaduna State, Nigeria. American International Journal of Contemporary Research. Vol.3 N0.9; September.

cxxxvi. Okonkwo, C.0 (2009); Criminal Law in Nigeria, $2^{\text {nd }}$ ed, Ibadan, Spectrum Books LTD.

cxxxvii. Okoye, U.C. (2009); Insecurity in Nigeria Universities, Lagos This day, August 29th.

cxxxviii. Okpara, G.S (2002); Contemporary Marketing: Topical and Tropicalized, Enugu, John Jacob's classics.

cxxxix. Okpara, G.S., Anyanwu, A. and Inyanga, J.I..N (1999); Marketing Communications: Principles and Practice. Port Harcourt, Educational Books and Investments Limited.

cxl. Olatunji,S and Abioye, O. (2011);Lecturers,Students,Others killed in Kaduna. The Punch, Wednesday $20^{\text {th }}$ April.

cxli. Oludayo,T. and Ibrahim, A (2011);Social Organization of Internet Fraud among University Undergraduates in Nigeria, International Journal of Cyber Criminology, $\quad$ (IJCC),VOL 5(2), July-September)

cxlii. Omoegun, M and Akanle, F. (2007): Perceived Causes and effects of Cultism in Nigeria Universities: Prevention and Solutions with Counseling Implications, Journal of Sociology and Education in Africa, 6(1) 79-97.

cxliii. Onah, J.O and Thomas, M.J (1994); Marketing Management: Strategies and Cases, $2^{\text {nd }}$ ed, Enugu, Institute for Development Studies, University of Nigeria.

cxliv. Onah, J.O, Ndolo, S.I and Allison, P.U ed. (2006); Marketing and Management Practice in Nigeria, Enugu, African Marketing Development Foundation.

cxlv. Onyeke,J.K. (1999); Marketing Promotion Management, Enugu,Lano Publishers.

cxlvi. Opaluwa,A. (2009); Cultism and Nigeria Campuses: The Way Out.http:WWW.gamji.com

cxlvii. Ori, m. (2012); The way Nigerian Students in Tertiary Institutions take their Own lives, Lagos, The Sun Newspaper ,September 4.

cxlviii. Osalor,P (2010);Entrepreneurialism: The Solutions to combating youths 'crimes in Nigeria.Vanguard,28th March.

cxlix. O'Shaughnessy, J. (1992); Explaining Buyer Behavior: Central Concepts and Philosophy of Science Issues, New York Oxford University Press INC.

cl. Palmer, A. (2005); Principles of Services Marketing, $4^{\text {th }}$ ed, London, the McGraw-Hill companies.

cli. Perner, L (2010); Perception. WWW.Consumerpsychologist.com

clii. Perreault, W.D and McCarthy E.J (2003); Essentials of Marketing: A Global Managerial Approach, Boston Burr Ridge, McGraw-Hill Irwin.

cliii. Schultz, D. (2009); Here comes the chickens: Marketers need to sort out what establishes and maintains brands, Journal of Marketing Management, May/June, vol. 18 No.3 American Marketing Association.

cliv. Schltz, P. W, Nolan, J.M., Cialdim, R.B., Goldstein N.J., Griskevicius, V., (2007); The. 18(15). Constructive, Destructive and Reconstructive Power of Social Norms. Journal of Psychological Science

clv. Schatsky, D. (2006); Social Market Vs Social Marketing, Jupiter Research Analyst web logs. Jupiter Media.

clvi. Stones, E. (1979); An Introduction to Educational Psychology, Ibadan, Spectrum Books LTD.

clvii. Sulaiman, S.(2013); Police parade 12 students and a trader for cultism, The Nation Newspaper,July,4.

clviii. Swerdlick, M. (2008); The four Cs of Marketing Success, Journal of Marketing Health Services, Vol.28 No. 4, American Marketing Association.

clix. Sharp, B. (2008); Net Promoter Score fails the Test: Market Research Buyers Beware. Journal of Marketing Research, winter.

clx. Sherman, L. (1993); Policing Domestic Violence: American Journal of Criminology, Summer, Pg. 12.

clxi. Sharma, D.D. (2010); Marketing Research: Principles, Applications and Cases, New Delhi, Sultan Chand and Sons Educational Publishers.

clxii. Sincich, T. (1986); Business Statistics by example 2nd ed., San Francisco, Dellen Publishing Company.

clxiii. Singer, J. (2009); Statistics, Microsoft Encarta

clxiv. Tapp, A. (1998); Principles of Direct and Database Marketing, Harlow Financial Times (Prentice Hall).

clxv. Theo, A. (1998); Sociology, $5^{\text {th }}$ ed, New York Longman.

clxvi. Tobi, S. (2012); Abia Gang Rape: AGF demands Police Report, Lagos, This day, January 21.

clxvii. Tull, D.S., and Hawkins, D. I., (2005); Marketing Research: Measurement and Method, $6^{\text {th }}$ ed., New Delhi, Prentice Hall of India.

clxviii. Trafficking in persons (Prohibition) Law Enforcement and Administration ACT 2004.

clxix. Tull, D.S., and Hawkins, D. I., (2005); Marketing Research: Measurement and Method, $6^{\text {th }}$ ed., New Delhi, Prentice Hall of India .

clxx. Urieto, J.E. (1995); Business Statistics: A practical Approach, Port-Harcourt, Paragraphics.

clxxi. Uwujare, N (2012); Two Graduates, Technician arrested for Kidnapping, Lagos, Daily Sun, October 18.

clxxii. Uwujare, N (2013); Poly student leads deadly robbery gang, Lagos, Daily Sun, June 13.

clxxiii. Uzoma, A.M. (1992); Operations Research and Quantitative Methods for the Management Sciences, Aba, Frontier Publishers Limited. 
clxxiv. Walker, O.C, Boyd H.W, Mullins J. and Larreche J. (2003); Marketing Strategy: A Decision Focused Approach, $4^{\text {th }}$ ed, Boston Burr Ridge McGraw-Hill Irwin.

clxxv. Waziri,A.(2010); Minister charges youths on credible polls, Lagos, This day Newspaper,August 25.

clxxvi. Weinreich, N. K. (2010); Hands on Social Marketing; A step-by-step guide to designing change for good, $2^{\text {nd }}$ ed. New York Sage Publications.

clxxvii. Wells,W.,Moriathy,S., and Burnet,J, (2007); Advertising: Principles and Practice, 7th ed. New Delhi, Prentice Hall of India.

clxxviii. World Bank Report (2004); Making Services Work for poor People: Overview, Washington D.C, The International Bank for Reconstruction and Development (the World Bank).

clxxix. www.wikipedia.com (2012)

clxxx. www.wikipedia.com (2016); Services Quality

clxxxi. www.wikipedia.com (2016);Obafemi Awolowo University massacre

clxxxii. www.managementstudyguide.com (2016);Services Marketing: Definition and characteristics.

clxxxiii. www.nairaland.com (2016);Akwa Ibom State University expels 6 students for involvement in criminal acts.

clxxxiv. www.ojjdp.gov/action.(2016);Reduce Youths' involvement with guns,Drugs and Gangs

clxxxv. www.slideshare.net (2016);Services Marketing:Services Quality Gaps Model

clxxxvi. www.slideshare.net (2016);Services Marketing:Services and Relationship marketing

clxxxvii. Yaldin,D (1998); Public Relations, $5^{\text {th }}$ ed. Harlow, England, Prentice Hall, Financial Times.

clxxxviii. Yarimoglu, K.E. (2014); A Review on Dimensions of Service Quality Models. Journal of Marketing Management, (June) Vol.2 No 2 PP 79-93.

clxxxix. Zeithaml, V.A. and Bitner, M.J. (2000); Services Marketing: Integrating Customer Focus across the Firm, 2nd ed, Boston Burr Ridge, Irwin McGraw-Hill

cxc. Zeithaml, V.A., Parasurraman, A. and Berry, L.L. (1990); Delivering Quality Service: Balancing Customer Perceptions and Expectations. New York, Free Press.

cxci. Zeithaml, V.A., Parasurraman, A. and Berry, L.L. (1988); SERVQUAL: A multiple-item scale for measuring consumer perceptions of Service Quality: Journal or retailing,VOL.64,Spring.

cxcii. Zeithaml, V.A., Parasurraman, A. and Berry, L.L. (2016); The Rater Model: Five ways to measure service, A strategy skills training from Mind Tools.com

Department of Marketing

\section{Appendix}

Abia State University, Uturu

Dear Student,

The questions enclosed are specifically meant for a Thesis presentation in partial fulfillment of an award of a PhD Degree in Marketing. The topic is ASSESSING THE PERCEPTION OF NIGERIA UNDERGRADUATES ON SERVICES MARKETING MODEL AS TOOL FOR PREVENTION AND CONTROL OF CRIME AMONG UNDERGRADUATES.

You are please requested to kindly tick in the appropriate options or answers provided which correspond with your choice, and also state clearly your comments or recommendations where necessary. All answers shall be treated with strict confidence and used for the purpose of this study only.

Thanks for your support.

Yours Sincerely,

Madu Jude E.

08033746612

\section{Section A}

In this section a 5- point likest scale have seen used to represent what your opinion could be. SA means strongly agree. A, means agree, D means disagree, SD means strongly disagree, while U means undecided. Please indicate the option that best represent your opinion in each question. 


\begin{tabular}{|c|c|c|c|c|c|c|}
\hline S/NO & Part 1: Services Marketing Tools for Crime Prevention and Control & A & SA & D & SD & $\mathbf{U}$ \\
\hline & Among Undergraduates & 5 & 4 & 3 & 2 & 1 \\
\hline 1 & $\begin{array}{l}\text { The following services marketing tools can prevent and control crime } \\
\text { among undergraduates in Nigeria universities: }\end{array}$ & & & & & \\
\hline & (a) Provision of quality education service quality by the Universities & & & & & \\
\hline & (b) Positive staff attitude to students & & & & & \\
\hline & $\begin{array}{l}\text { (c) Posting Good and educative Messages on the social media or } \\
\text { Networks. }\end{array}$ & & & & & \\
\hline & $\begin{array}{c}\text { (d) Sponsoring Advertisements through selected media with messages } \\
\text { carrying the consequences of crime among undergraduates in } \\
\text { universities. }\end{array}$ & & & & & \\
\hline & $\begin{array}{l}\text { (e) Carrying out Public relations activities by the universities aimed at } \\
\text { prevention and control of Crime among undergraduates }\end{array}$ & & & & & \\
\hline & $\begin{array}{l}\text { (a) Carrying out publicity activities by the universities aimed at } \\
\text { prevention and control of Crime among undergraduates }\end{array}$ & & & & & \\
\hline 2 & $\begin{array}{l}\text { High quality education service rendered by the universities can } \\
\text { contribute to prevention and control of crime } \\
\text { among undergraduates if they are in the form of: }\end{array}$ & & & & & \\
\hline & $\begin{array}{c}\text { (a) RELIABILTY: the services are dependable, shows great benefits to } \\
\text { undergraduates and less costly. }\end{array}$ & & & & & \\
\hline & $\begin{array}{l}\text { (a) TANGIBLES: provision of physical facilities such as laboratories, } \\
\text { libraries, electricity supply, conducive class rooms and learning } \\
\text { environment. }\end{array}$ & & & & & \\
\hline & $\begin{array}{l}\text { (b) RESPONSIVENESS: reduced steps taken by undergraduates to } \\
\text { receive the services, giving undergraduates prompt response to their } \\
\text { enquiries or complaints and giving them easy and prompt access to the } \\
\text { facilities. }\end{array}$ & & & & & \\
\hline & $\begin{array}{l}\text { (d) ASSURANCE: ability to convey trust, confidence, and competence to } \\
\text { the undergraduates in a courteous manner. }\end{array}$ & & & & & \\
\hline & $\begin{array}{l}\text { (e) EMPATHY: giving carring, friendly and individualized attention to the } \\
\text { undergraduates. }\end{array}$ & & & & & \\
\hline 3 & $\begin{array}{c}\text { Attitude of staff (personnel) in universities can contribute to prevention } \\
\text { and control of crime among }\end{array}$ & & & & & \\
\hline & undergraduates if they come in the following forms: & & & & & \\
\hline & (a) regular attendance to class by lecturers & & & & & \\
\hline & $\begin{array}{c}\text { (b) using teaching methods that are good and keep undergraduates very } \\
\text { busy }\end{array}$ & & & & & \\
\hline & (c) giving undergraduates easy and free access to their results and staff & & & & & \\
\hline & (d) always wearing a friendly mood before undergraduates & & & & & \\
\hline & (e) ability to act as change agents to undergraduates through counseling. & & & & & \\
\hline 4 & $\begin{array}{l}\text { Information through the following social media or networks contributes } \\
\text { to crime prevention and control among undergraduates. }\end{array}$ & & & & & \\
\hline 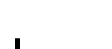 & (a) Facebook & & & & & \\
\hline & (b) Skype-twitter & & & & & \\
\hline & (c) Whats-app & & & & & \\
\hline & (d) 2-go/Eskimo & & & & & \\
\hline & (e) MNS & & & & & \\
\hline & (f) Foursquare & & & & & \\
\hline 5 & $\begin{array}{l}\text { Advertisements with the consequences of crime can help control and } \\
\text { prevent crime among undergraduates if they are transmitted through } \\
\text { the following media: }\end{array}$ & & & & & \\
\hline & (a) Billboards & & & & & \\
\hline & (b) Newspapers/Magazines & & & & & \\
\hline & (b) Radio & & & & & \\
\hline & (d) Television & & & & & \\
\hline
\end{tabular}




\begin{tabular}{|c|c|c|c|c|c|c|}
\hline \multirow[t]{2}{*}{ S/NO } & \multirow{2}{*}{$\begin{array}{c}\text { Part 1: Services Marketing Tools for Crime Prevention and Control } \\
\text { Among Undergraduates }\end{array}$} & $\mathbf{A}$ & SA & D & SD & $\mathbf{U}$ \\
\hline & & 5 & 4 & 3 & 2 & 1 \\
\hline \multirow[t]{10}{*}{6} & $\begin{array}{l}\text { Public relations activities by the universities can control and prevent } \\
\text { crime among undergraduates if done in the following forms: }\end{array}$ & & & & & \\
\hline & $\begin{array}{c}\text { (a) Donating free buses to ease undergraduates' transportation } \\
\text { problems. }\end{array}$ & & & & & \\
\hline & $\begin{array}{l}\text { (b) Sponsoring of sporting activities among undergraduates with huge } \\
\text { financial rewards to Winners. }\end{array}$ & & & & & \\
\hline & $\begin{array}{l}\text { (c) Sponsoring special academic activities among undergraduates such } \\
\text { as essays, and quiz competition, science/technology competitions and } \\
\text { exhibitions both locally and overseas. }\end{array}$ & & & & & \\
\hline & $\begin{array}{l}\text { (d) Donation of vehicles, furnished offices and accommodation and } \\
\text { budgetary allocations to student's union government. }\end{array}$ & & & & & \\
\hline & $\begin{array}{l}\text { (e) Sponsoring of social activities among undergraduates such as most } \\
\text { beautiful girl in campus, and students' week. }\end{array}$ & & & & & \\
\hline & $\begin{array}{l}\text { (f) Sponsoring trade fairs and exhibitions in the institutions with } \\
\text { undergraduates as sales persons to the participants. }\end{array}$ & & & & & \\
\hline & $\begin{array}{l}\text { (g) Donation of cafeteria and bars where foods and drinks are sold to the } \\
\text { students at subsidized prices. }\end{array}$ & & & & & \\
\hline & (h )building and donating sports and recreation facilities to the students. & & & & & \\
\hline & $\begin{array}{c}\text { (h) Using institutions' internal magazines to publish efforts of the } \\
\text { institutions aimed at assisting the students }\end{array}$ & & & & & \\
\hline \multirow[t]{7}{*}{7} & $\begin{array}{l}\text { Publicity activities containing the consequences and constituents of } \\
\text { crime by universities can control and }\end{array}$ & & & & & \\
\hline & Prevent crime if done in the following forms: & & & & & \\
\hline & (a) press or news releases & & & & & \\
\hline & (b) Press conferences & & & & & \\
\hline & (c) Feature articles & & & & & \\
\hline & (d) Photographs, & & & & & \\
\hline & (e) films and videotapes & & & & & \\
\hline
\end{tabular}

Table 47: Scales/ Rating

Section B Demographic Variables of Respondents

\begin{tabular}{|c|c|c|}
\hline Sex: & (a) & Male \\
\hline & (b) & Female \\
\hline Age: & (a) & $17-20$ years \\
\hline & (b) & $21-25$ years \\
\hline & (c) & $26-30$ years \\
\hline & (d) & 31 and above \\
\hline
\end{tabular}

10. What level are you in the University?
(a) 100 level
(b) 200 level
(c) 300 level
(d) 400 level
(e) 500 level
(f) Post Graduate

11 University: (a) Abia State University,Uturu.

(b) Ebonyi State University, Abakaliki

(c) Federal University of Technology, Owerri.

(d) Nnamdi Azikiwe University, Awka.

(e) University of Nigeria, Enugu Campus.

Sample of Interview Questions for Chief Security Officers of the Tertiary Institutions

- From your experience, what form of crime do students in your university mostly get involved in?

- Generally, what steps or measures have your university taken to prevent or control crime among students in your university?

- What do you think are the barriers to the efforts on prevention of and control of crime among students in your university

- In what form do your institution offer quality education services to your students with the aim of preventing and controlling crime among students? 
- How does your university encourage cordial relationship between staff and students?

- How does your university encourage positive attitude of staff on students with the aim of realizing crime prevention and control among students?

- Which advertising media does your university use to disseminate information about the consequence of crime among your students?

- Which social media do your university use, and which one would you recommended for crime prevention and control among students in your university?

- Which public relations and publicity activities does your university use for crime prevention and control among students in your university?

- Which other public relations and publicity activities would you recommend that can best achieve crime prevention and control among students in your university?

- Generally how would you access or rate the result of the efforts by your university to prevent and control crime among students? 